
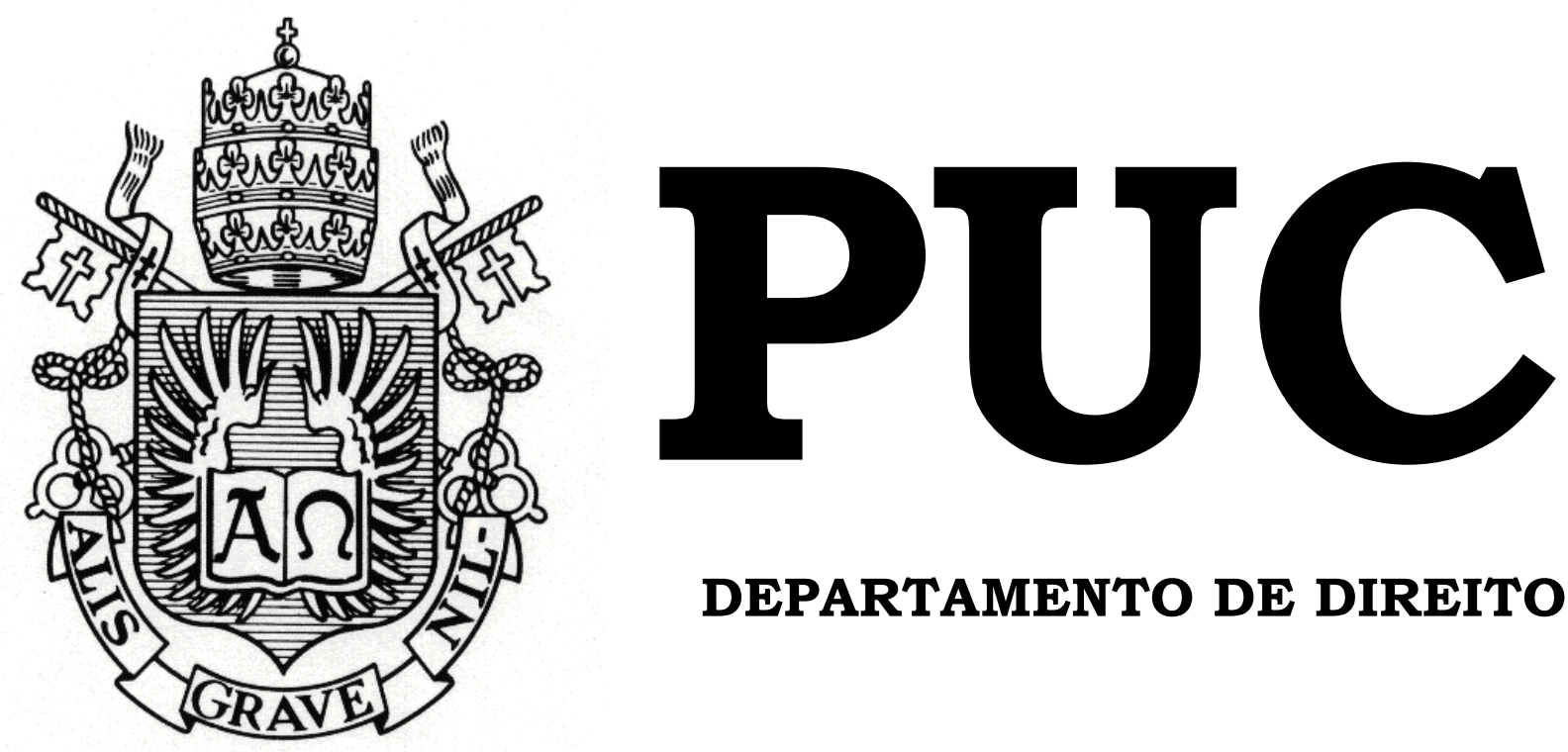

DEPARTAMENTO DE DIREITO

\title{
EFEITOS DA PRISONIZAÇÃO: A INEFICÁCIA DA PRISÃO COMO SANÇÃO PENAL
}

por

LUISA DE ARAUJO TAVARES

ORIENTADOR: CARLOS RAYMUNDO CARDOSO

2017.2

PONTIFÍCIA UNIVERSIDADE CATÓLICA DO RIO DE JANEIRO

RUA MARQUÊS DE SÃO VICENTE, 225 - CEP 22453-900

RIO DE JANEIRO - BRASIL 


\title{
EFEITOS DA PRISONIZAÇÃO: A INEFICÁCIA DA PRISÃO COMO SANÇÃO PENAL
}

\author{
por \\ LUISA DE ARAUJO TAVARES
}

Monografia apresentada ao Departamento de Direito da Pontificia Universidade Católica do Rio de Janeiro (PUC-Rio) para a obtenção do Título de Bacharel em Direito.

Orientador: Carlos Raymundo Cardoso. 


\section{DEDICATÓRIA}

À minha bisavó, Thereza, minha maior saudade, pelo amor incondicional e por nunca deixar de olhar por mim mesmo quando se tornou estrela.

À minha avó, Aurélia, minha fonte de inspiração, por toda a força e fé compartilhadas para que eu voe, sem medo, cada vez mais alto. 


\section{AGRADECIMENTOS}

À minha mãe, Roberta Ramos, e ao meu padrasto, Ricardo Ramos, por todo o suporte e apoio, emocional e financeiro, durante a minha trajetória até este trabalho de conclusão de curso. Devo a eles a experiência do intercâmbio que, de tão engrandecedora, me permitiu caminhar firme até este momento com diversos projetos realizados, incluindo esta monografia.

Ao meu orientador, Carlos Raymundo Cardoso, pela paciência e atenção comigo e com o meu estudo. Agradeço toda a sua disponibilidade para encontros semanais que me impulsionaram a vencer os desafios surgidos ao longo dessa empreitada. As trocas de experiências, os debates sobre a bibliografia, as análises dos filmes - tudo me possibilitou dar passos largos nesta pesquisa, desenvolvendo reflexões imprevisíveis e surpreendentes.

Ao meu professor, supervisor e mentor, André Perecmanis, por todo o encorajamento para que eu me questionasse e pensasse criticamente; com quem tive a honra de trabalhar no Núcleo da PUC e aquele que, no decorrer de dois anos, me permitiu crescer e amadurecer como aluna, como monitoraestagiária e como pessoa, incentivando leituras e estimulando vivências que quebraram premissas minhas pré-fixadas; e quem me apresentou ao trabalho de Augusto Thompson, gerando em mim a vontade de escrever sobre o tema.

À minha professora Samantha Pelajo, mediadora espetacular, com quem tive o privilégio de aprofundar meus estudos em Mediação e Práticas Colaborativas, o que me permitiu o contato com a lógica da Justiça Restaurativa, essencial para o desencadeamento da análise proposta. Através dela, conheci Celia Passos e Maria do Céu Battaglia, para uma entrevista coletiva sobre concepções de justiça. Agradeço às três por conversarem comigo, uma troca valiosa para a conclusão deste trabalho.

Ao meu melhor amigo, Diogo Motta, maranhense dos olhos verdes, pelo companheirismo em todos os momentos, por me incentivar diariamente a ser alguém melhor e não me deixar desistir daquilo que desejo e acredito, como foi quando decidi escrever sobre este tema tão polêmico. 


\section{RESUMO}

A presente monografia tem por objetivo demonstrar o antagonismo entre os dois mundos separados pelos muros do complexo penitenciário, bem como a maneira que os valores e padrões prisionais impregnam e afetam todos aqueles que integram a sociedade do cárcere - seja de forma temporária, seja mais duradoura. Dessa forma, o estudo inclui um decorrer histórico acerca da solidificação do caráter sancionatório da prisão, adquirido por demandas políticas e econômicas. As reflexões sobre o sistema retributivo-punitivo atual - muito distante de efetivar a tão visada ressocialização, por ser inatamente contraditório em suas finalidades -, com maior enfoque na realidade dos presídios brasileiros, deflagram a urgência de uma mudança de paradigma cultural, sugerindo-se a implementação de uma concepção de justiça restaurativa, sem descartar a inevitabilidade de um período de transição. Visto que a dinâmica restaurativa trabalha com ferramentas de autoimplicação, delinquentes com perfis psicopáticos revelam-se uma exceção, sendo imperioso o estímulo de neurônios-espelho na atividade cerebral desses indivíduos com carência de empatia.

\section{PALAVRAS-CHAVE}

Direito de Punir - Prisão-Sanção - Humanização das Penas Ilegitimidade Penal - Contradições - Prisonização - Penas Alternativas Quebra de Paradigmas - Concepção de Justiça - Autoimplicação. 


\section{SUMÁRIO}

INTRODUÇÃ

\section{CAPÍTULO 1. A TRANSFORMAÇÃO DA PRISÃO-CUSTÓDIA EM PRISÃO-PENA ...................................................................................... 10}

\section{CAPÍTULO 2. PRISONIZAR PARA SOBREVIVER ............................20}

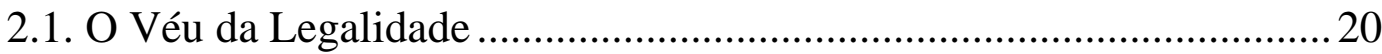

2.2. As Contradições da Pena Privativa de Liberdade e a Consequente Prisonização Formulada por Augusto Thompson ..........................................2 24

2.3. O Processo de Prisonização da Massa Carcerária a partir do Experimento

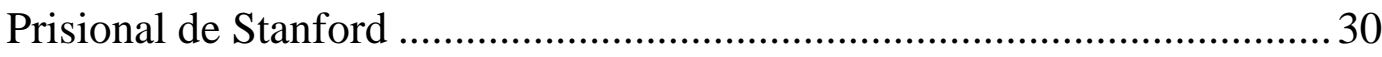

2.4. A Real Extensão dos Valores e Padrões Vigorantes na Penitenciária . 36

\section{CAPÍTULO 3. NOVOS RUMOS NA EXECUÇÃO PENAL}

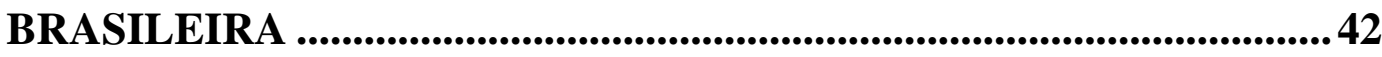

3.1. Inversão na Lógica do Sistema Progressivo-Regressivo como Ferramenta de Transição Pensada por Augusto Thompson ........................... 42

3.2. O Método da Associação de Proteção e Assistência aos Condenados

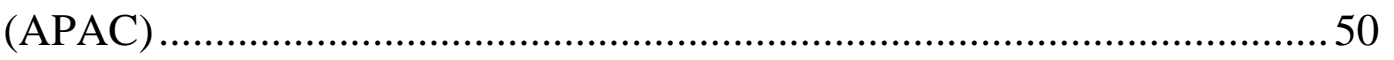

3.3. Expansão nas Hipóteses de Cabimento das Penas Restritivas de Direito 52

3.4. Implementação e Predominância de uma Justiça Restaurativa Baseada no Uso de Ferramentas Autoimplicativas......................................................55

3.5. O Estímulo dos Neurônios-espelho em Quadros Psicopáticos ..............63 63

CONCLUSÃO

REFERÊNCIAS BIBLIOGRÁFICAS .................................................. 72 


\section{LISTA DE ABREVIAÇÕES}

VEP - Vara de Execuções Penais

DESIPE - Departamento do Sistema Penal

SUSIPE - Superintendência do Sistema Penitenciário

CNJ - Conselho Nacional de Justiça

PLS - Projeto de Lei do Senado

APAC - Associação de Proteção e Assistência aos Condenados

ILANUD - Instituto Latino-americano das Nações Unidas para Prevenção do Delito e Tratamento do Delinquente 
"Liberdade é pouco. O que desejo ainda não tem nome."

(Clarice Lispector) 


\section{INTRODUÇÃO}

A opção pelo encarceramento, em uma sociedade dotada de valores retributivos-punitivos, é quase que uma consequência natural de qualquer infração penal ou crime cometidos. Assim como qualquer outro instituto movido por interesses políticos, o complexo penitenciário foi, e ainda é, um instrumento utilizado para atender interesses e necessidades de uma classe econômica mais forte e dotada de maior influência dentro da lógica do capitalismo. Desse modo, nota-se que o sistema penal é seletivo quanto à sua clientela, atuando, a partir do respaldo de leis presumidamente dotadas de legitimidade, de maneira arbitrária e segregadora.

Com isso, inicialmente, será apresentada uma cronologia para justificar o surgimento da prisão com caráter sancionador, ou, trocando em miúdos, como a prisão-custódia, no decorrer histórico, se transforma em prisão-pena. Demonstrar-se-á, assim, como aspectos econômicos e, até mesmo, religiosos estão intrinsecamente ligados com tal emergência, que visa oficialmente a: retribuir o mal causado, prevenir a prática de novos delitos e reeducar o preso para a vida em sociedade.

Uma vez elencadas as finalidades da prisão-sanção, em ato contínuo, serão expostas as contradições e divergências entre elas, salientando assim o paradoxo flagrante em regenerar os detentos por meio de castigos e intimidações. Diante de tal conjuntura, os reais objetivos da célula penitenciária passam a ser garantir segurança e disciplina, de modo a evitar por parte dos apenados fugas ou rebeliões que acendam as insatisfações com consequentes protestos - da comunidade livre.

Assim sendo, em um segundo momento, analisar-se-á como o ambiente prisional afeta o ser humano tanto em um viés psíquico como também em uma diretriz comportamental. Os muros da penitenciária não apenas separam os encarcerados daqueles que vivem em liberdade; mais que isso, eles marcam distintos modos e estilos de vida. Punições abusivas, comandos vexatórios e práticas humilhantes - que causariam espanto e 
indignação para o mundo dos direitos humanos - são bem aceitas e justificadas na vida intramuros, visto que o sistema social da prisão é engendrado por outros princípios e crenças. Verificar-se-á, em seguida, que a prisonização - instituto e conceito formulado por Augusto Thompson ocorre não somente nos destinatários dos castigos (os presos), mas também naqueles que ditam o comando (direção carcerária), nos que executam a ordem (guarda prisional) e nos profissionais com expertise terapêutica; ou seja, em todos os integrantes da sociedade prisional.

Por fim, entendendo a necessidade da extinção do encarceramento e levando em consideração o panorama do Brasil, serão enumeradas propostas transitórias para tornar o cárcere mais humanizado - a começar pela superlotação dos presídios brasileiros -, em uma estrada cujo destino é a implementação de uma ética de justiça aplicada, visando a solucionar os conflitos emergentes por um processo restaurativo que implica responsabilização, sem desconsiderar a capacidade de transformação tanto dos delinquentes como também das vítimas diante do dano causado.

Além disso, abarcará o estudo aqueles que não conseguem de forma espontânea desenvolver empatia pelo outro e se autoimplicar, situação na qual será encorajado o estímulo do sistema cerebral de espelhamento presente em todo ser humano. O homem é um ser social, aprisioná-lo para regenerar é tentar conter um incêndio com gasolina. 


\title{
CAPÍTULO 1. A TRANSFORMAÇÃO DA PRISÃO-CUSTÓDIA EM PRISÃO-PENA
}

\begin{abstract}
A prisão é uma exigência amarga, mas imprescindível. A história da prisão não é a de sua progressiva abolição, mas a de sua reforma. A prisão é concebida modernamente como um mal necessário, sem esquecer que a mesma guarda em sua essência contradições insolúveis. ${ }^{1}$ - Grifo Nosso.
\end{abstract}

As palavras em epígrafe, retiradas da obra de Cezar Roberto Bitencourt, foram escolhidas pelo autor para iniciar sua análise a respeito da pena de prisão, o objeto principal de estudo desta monografia. Certo é que o encarceramento com a privação da liberdade nem sempre, no decorrer histórico, foi dotado de caráter sancionatório.

Antes de adentrar os aspectos da prisão como um instrumento punitivo, faz-se necessário dar um passo atrás e entender a origem não somente das penas como também do direito de punir em si, o que obriga a um resgate das reflexões de grandes filósofos como Hobbes, Locke e Rousseau: pensadores que elaboraram teorias contratualistas, ou seja, entendem que a formação e organização do Estado se fez a partir do contrato social. Muito embora sejam notórias as divergências das ponderações entre eles, há uma convergência quanto à indispensabilidade de um consenso entre os cidadãos para a garantia de suas próprias existências.

De acordo com a linha hobbesiana, "o homem é o lobo do próprio homem"2, o que faz de Hobbes um defensor do regime monárquico, uma vez que, considerando ser o homem mau por natureza e constantemente dominado por suas paixões, incumbe ao Estado - pela figura do soberano absoluto - a função de preservar a vida dos indivíduos que possuem uma tendência em dominar seus semelhantes. Locke, em contrapartida, entende que os homens são seres dotados de razão e que possui o Estado - uma

\footnotetext{
${ }^{1}$ BITENCOURT, Cezar Roberto. Tratado de Direito Penal - Parte Geral 1. 19.ed. São Paulo: Editora Saraiva, 2013. Terceira Parte, Capítulo XXVIII, História e Evolução da Pena de Prisão, p. 577.

${ }^{2}$ HOBBES, Thomas. Leviatã - ou matéria, forma e poder de um Estado eclesiástico e civil. Coleção Os Pensadores. São Paulo: Nova Cultural, 1997, p. 25.
} 
instância superior distante - o dever de resguardar a vida, a liberdade e a propriedade privada de cada cidadão. Dessa maneira, nota-se ser Locke um simpatizante do modelo burguês. Rousseau, por sua vez, considera que a formação do Estado Social ocorreu quando os cidadãos livres abandonaram as suas respectivas "vontades individuais" em nome de uma "vontade geral" que promovesse o bem-estar de todos. Assim sendo, a soberania pertence ao povo, e o governante nada mais é do que o seu representante submisso. Justamente por entender que "o poder emana do povo" 3 , traz em seu pensamento político o engendramento de um sistema democrático - tanto pela via da democracia direta, como também por meio da democracia representativa. Para a corrente rousseauniana, diferentemente de Hobbes, " $o$ homem é bom por natureza, mas a sociedade o corrompe"4 e, visto que "o homem nasce livre, mas por toda parte encontra-se aprisionado", cabe ao Estado garantir que as leis sejam justas, para que assim haja o resgate de uma liberdade próxima à do Estado de Natureza.

Portanto, constata-se que o pacto social nada mais é do que a renúncia da total liberdade gozada no Estado de Natureza, em nome de uma maior segurança para a preservação e o usufruto de elementos essenciais. Consubstancia-se em um sacrifício da liberdade individual para a realização de um bem geral. Iluminado por esses conceitos, Cesare Beccaria, em seu trabalho Dos delitos e das penas, defende que "o direito de castigar não pertence a qualquer cidadão em particular; é das leis, que são o órgão da vontade geral" $" 6$ ainda leciona que:

Desse modo, somente a necessidade obriga os homens a ceder uma parcela de sua liberdade; disso advém que cada qual apenas concorda em pôr no depósito comum a menor porção possível dela, quer dizer, exatamente o que era necessário para empenhar os outros em mantê-lo na posse do restante. A reunião de todas

\footnotetext{
${ }^{3}$ ROUSSEAU, Jean-Jacques. O contrato social e outros escritos. Tradução: Rolando Roque da Silva. 5.ed. São Paulo: Ed. Cultrix, 1995, p. 40.

${ }^{4}$ Ibid., p. 23.

${ }^{5}$ Ibid., p 76.

${ }^{6}$ BECCARIA, Cesare. Dos delitos e das penas. Tradução: Torrieri Guimarães. 7.ed. São Paulo: Editora Martin Claret Ltda., 2013. Capítulo XX, Da inevitabilidade das penas e das graças, p. 59.
} 
essas pequenas parcelas de liberdade constitui o fundamento do direito de punir. ${ }^{7}$ - Grifo Nosso.

Ademais, relevante dizer que, em sua obra, Beccaria muito se inspira em Do espírito das leis de Montesquieu, considerado um dos grandes filósofos do Iluminismo, que formulou o princípio da Separação dos Poderes. Tal abordagem, no entanto, para melhor desencadeamento da proposta deste trabalho, será feita mais adiante. Ainda a respeito do nascimento do direito de punir, Foucault manifesta:

Supõe-se que o cidadão tenha aceito de uma vez por todas, com as leis da sociedade, também aquela que poderá puni-lo. $\mathrm{O}$ criminoso aparece então como um ser juridicamente paradoxal. Ele rompeu o pacto, é portanto inimigo da sociedade inteira, [...]. Efetivamente a infração lança o indivíduo contra todo o corpo social; a sociedade tem o direito de se levantar em peso contra ele, para puni-lo. Luta desigual: de um só lado todas as forças, todo o poder, todos os direitos. E tem mesmo que ser assim, pois aí está representada a defesa de cada um. $^{8}$ - Grifo Nosso.

Até o final do século XVIII, a pena recebida pelo homem delinquente era fundamentalmente aplicada sobre o seu corpo - morte, mutilações, açoites. Nas palavras de Foucault, a punição no sistema penal baseava-se nos suplícios. Inclusive, Foucault inicia Vigiar e punir - nascimento da prisão descrevendo a celebração da execução física de Damiens, um indivíduo que fora condenado

a pedir perdão publicamente diante da porta principal da Igreja de Paris [aonde devia ser] levado e acompanhado numa carroça, nu, de camisola, carregando uma tocha de cera acesa de duas libras; [em seguida], na dita carroça, na Praça de Grève, e sobre um patíbulo que aí será erguido, atenazado nos mamilos, braços, coxas e barrigas das pernas, sua mão direita segurando a faca com que cometeu o dito parricídio, queimada com fogo de enxofre, e às partes em que será atenazado se aplicarão chumbo derretido, óleo fervente, piche em fogo, cera e enxofre derretidos conjuntamente, e a seguir seu corpo será puxado e desmembrado por quatro cavalos e seus membros e corpo consumidos ao fogo, reduzidos a cinzas, e suas cinzas lançadas ao vento. ${ }^{9}$

\footnotetext{
${ }^{7}$ BECCARIA, Cesare. Dos delitos e das penas. Tradução: Torrieri Guimarães. 7.ed. São Paulo: Editora Martin Claret Ltda., 2013. Capítulo II, Origem das penas e do direito de punir, p. 17.

${ }^{8}$ FOUCAULT, Michel. Vigiar e punir: nascimento da prisão. Tradução: Raquel Ramalhete. 42.ed. Petrópolis: Editora Vozes, 2014. Segunda Parte: Punição, Capítulo I - A punição generalizada, p. 76. ${ }^{9}$ FOUCAULT, Michel. Vigiar e punir: nascimento da prisão. Tradução: Raquel Ramalhete. 42.ed. Petrópolis: Editora Vozes, 2014. Primeira Parte: Suplício, Capítulo I - O corpo dos condenados, p. 9.
} 
Percebe-se que a prisão se resumia apenas a uma custódia do condenado para viabilizar a efetiva aplicação da pena que lhe havia sido imposta. Nas palavras de Cezar Bitencourt, "a prisão era uma espécie de 'antessala' de suplícios"10. Essa única finalidade de contenção presente na privação da liberdade - desde a Antiguidade com os gregos e romanos persiste na Idade Média. Todo esse ritual de violência explícita, muitas vezes, gerava na população um sentimento de piedade em relação ao condenado, de maneira que a violência legal do executor perdia legitimidade, visto que a figura do carrasco acabava por se confundir com a do delinquente. Como bem versa Foucault, "a execução pública é vista então como uma fornalha em que se acende a violência" 11 , mostrando-se contrária ao principal objetivo do implemento dos castigos: prevenir o delito - muito embora também se pretendesse retribuir o mal causado. Cesare Beccaria defende que:

Ainda que os castigos cruéis não se opusessem diretamente ao bem público e à finalidade que se lhes atribui, a de obstar os crimes, será suficiente provar que essa crueldade é inútil, para considerá-la então odiosa, revoltante, em desacordo com a justiça e com a natureza mesma do contrato social. ${ }^{12}$ - Grifo Nosso.

Corresponde à época moderna o momento histórico em que de fato ocorre a humanização das penas, marcada pelo deslocamento da essencialidade do castigo: antes direcionado ao corpo, passa a possuir como foco a alma. Dessa forma, a incidência da pena - até então meramente com um caráter retributivo-preventivo - inova em suas finalidades, sendo valorada com o aspecto da reeducação, conceito esse em que se encontram inseridos os ideais de ressocialização, salvação e cura da alma do criminoso. Ademais, no que concerne a essa transição, Cezar Roberto Bittencourt faz uma alusão à influência do Direito Canônico:

O Direito Canônico contribuiu decisivamente para com o surgimento da prisão moderna, especialmente no que se refere às primeiras ideias sobre a reforma do

\footnotetext{
${ }^{10}$ BITENCOURT, Cezar Roberto. Tratado de Direito Penal - Parte Geral 1. 19.ed. São Paulo: Editora Saraiva, 2013. Terceira Parte, Capítulo XXVIII, História e Evolução da Pena de Prisão, p. 578.

${ }^{11}$ FOUCAULT, Michel. Vigiar e punir: nascimento da prisão. Tradução: Raquel Ramalhete. 42.ed. Petrópolis: Editora Vozes, 2014. Primeira Parte: Suplício, Capítulo I - O corpo dos condenados, p. 14.

${ }^{12}$ BECCARIA, Cesare. Dos delitos e das penas. Tradução: Torrieri Guimarães. 7.ed. São Paulo: Editora Martin Claret Ltda., 2013. Capítulo III, Consequências desses princípios, p. 19.
} 
delinquente. (...) Essa influência veio completar-se com o predomínio que os conceitos teológico-morais tiveram, até o século XVIII, no Direito Penal, já que se considerava que o crime era um pecado contra as leis humanas e divinas. ${ }^{13}$ - Grifo Nosso.

Dessa forma, é apenas com o desaparecimento dos espetáculos da punição física - em princípios do século XIX - que as prisões ganham uma conotação de pena visando à correção dos apenados por meio do trabalho e da disciplina. Ocorre, assim, uma mudança na forma punitiva até então dominante, impulsionada por ideias positivistas que levam - nos dizeres de Cezar Roberto Bitencourt - "à transformação da prisão-custódia em prisãopena". ${ }^{14}$

Jean Mabillon, um monge beneditino francês, escreveu um livro intitulado Reflexões sobre as prisões monásticas. Essa obra considera a experiência punitiva do tipo carcerário que se havia aplicado no Direito Penal canônico e formula uma série de considerações que antecipam algumas das afirmações típicas do Iluminismo sobre o problema penal. Defende a proporcionalidade da pena de acordo com o delito cometido e a força física e espiritual do réu. Dá grande importância ao problema da reintegração do apenado à comunidade. ${ }^{15}$ - Grifo Nosso.

Nota-se, assim, que ao lado da proposta de reinserção social do penitenciado caminha a defesa da moderação na aplicação das penas como meio de concretização das suas próprias finalidades. Nas palavras de Beccaria:

O rigor do suplício não é o que previne os delitos com maior segurança, porém a certeza da punição, o zelo vigilante do juiz e essa severidade inalterável que só é uma virtude no magistrado quando as leis são brandas. A perspectiva de um castigo moderado, porém inflexível, provocará sempre uma impressão mais forte do que o vago temor de um suplício horrendo, em relação ao qual aparece alguma esperança de impunidade. ${ }^{16}$ - Grifo Nosso.

O século XIX, desde o seu princípio, já possui um modelo de sociedade capitalista embasada no liberalismo. Essa ideologia liberal dominante, consequentemente, proclama uma ordem social em que há uma

\footnotetext{
${ }^{13}$ BITENCOURT, Cezar Roberto. Tratado de Direito Penal - Parte Geral 1. 19.ed. São Paulo: Editora Saraiva, 2013. Terceira Parte, Capítulo XXVIII, História e Evolução da Pena de Prisão, p. 581-582.

${ }^{14}$ Ibid., p. 585.

${ }^{15}$ Ibid., p. 584.

${ }^{16}$ BECCARIA, Cesare. Dos delitos e das penas. Tradução: Torrieri Guimarães. 7.ed. São Paulo: Editora Martin Claret Ltda., 2013. Capítulo XX, Da inevitabilidade das penas e das graças, p. 59.
} 
intervenção mínima por parte do Estado. O que se observam são cidades industriais pautadas na premissa calvinista da ética do trabalho, ou seja, de que o trabalho dignifica o homem e, assim sendo, é por meio dele que se alcança o sucesso gerador da felicidade. Nesse sentido, a teórica Hilde Kaufmann afirma que

A pena privativa de liberdade foi produto do desenvolvimento de uma sociedade orientada à consecução da felicidade, surgida do pensamento calvinista cristão. $\mathrm{O}$ pensamento cristão, com algumas diferenças entre o protestantismo e o catolicismo, proporcionou, tanto no aspecto material como no ideológico, bom fundamento à pena privativa de liberdade. Por essa razão, não é causal que se considere que uma das poucas exceções à prisão-custódia do século XVI fosse a prisão canônica. ${ }^{17}$ - Grifo Nosso.

Com isso, há a constituição da classe operária: que detinha a força de trabalho, mas não os meios de produção; estes pertenciam à burguesia industrial. A existência de classes com interesses conflitantes acabou por dar ensejo a uma série de problemas, bem ilustrados nas seguintes palavras de Rosa del Olmo:

O desenvolvimento do capitalismo ao longo do século XIX demonstrou, na prática, que existiam contradições, evidenciadas particularmente nas crises econômicas e na luta de classes. Os empresários tomavam suas decisões segundo máximas de lucro, já que o fundamental era a acumulação de capital. Incrementou-se, portanto, a exploração da mão de obra, substituída, quando possível, pela máquina, criandose grandes massas de desempregados. As consequências foram muitas: aumentaram a pobreza, as epidemias e a delinquência. ${ }^{18}$ - Grifo Nosso.

Deflagra-se, portanto, uma instabilidade decorrente: (1) da contraposição entre a força produtiva do capital e do trabalho, (2) das lutas de classes com ameaça de revoluções por parte da classe proletária, (3) do aumento do desemprego, (4) da intensificação da pobreza, e (5) do maior índice de delinquência. Diante dessa realidade, o capitalismo e a ideologia liberal sofreram mudanças em seus conceitos. Assim, modificações na função do Estado tornaram-se necessárias dentro do contexto social emergente. Se antes se pretendia uma intervenção mínima, com escassa

\footnotetext{
${ }^{17}$ KAUFMANN, Hilde. Principios para la reforma de la ejecución penal. Buenos Aires: Depalma, 1977, p. 18-19.

18 DEL OLMO, Rosa. A América Latina e sua criminologia. Tradução: Francisco Eduardo Pizzolante e Sylvia Moretzsohn. 1.ed. Vol. 9 - Coleção Pensamento Criminológico. São Paulo: Editora Revan, 2004. Capítulo I - O surgimento da criminologia como ciência, p. 43.
} 
ingerência estatal na relação entre o capital e o trabalho, agora o Estado é chamado a intervir. Nasce o "Estado gestor"19, como bem descreve Tove Stang Dahl:

Um aspecto do imperialismo é particularmente importante para o desenvolvimento do controle social: o crescimento geral do poder e prestígio do Estado. O Estado imperialista não era um simples organismo mediador, mas uma instituição com seus próprios meios e fins. ${ }^{20}$ - Grifo Nosso.

Desse modo, resta clara a influência política e, principalmente, a motivação econômica no surgimento da prisão-pena. $\mathrm{O}$ confinamento, na lógica do regime capitalista dominante, não se preocupava com a cura do delinquente; o que o fazia necessário, como bem versa Michel Foucault, era o "imperativo do trabalho"21. Dario Melossi e Massimo Pavarini, inclusive, interpretam de forma semelhante a origem e a função da pena privativa de liberdade no capitalismo desenvolvido:

$\mathrm{O}$ trabalho, na maioria das vezes forçado, sempre esteve muito vinculado à prisão. A prisão surge quando se estabelecem as casas de detenção holandesas e inglesas, cuja origem se explica pela necessidade que existia de possuir um instrumento que permitisse não tanto a reforma ou reabilitação do delinquente, mas a sua submissão ao regime dominante. Outro efeito, agora sobre o exterior, o que os juristas chamam de prevenção geral, ou seja, uma função de intimidação, através da qual o trabalhador livre, antes de arriscar terminar na casa de trabalho ou prisão, prefere aceitar as condições impostas ao trabalho pela classe proprietária dos bens de produção. O regime da casa de correção visa, assim, além da absoluta premência que nela se dá ao trabalho, a acentuar papel dessa burguesia que o proletariado livre nunca aceitará completamente. A prisão é uma instituição subalterna à fábrica: já não se trata de dizer que a correção sirva para alcançar uma ideia metafísica e difusa de liberdade, mas que procura disciplinar um setor da força de trabalho para introduzi-lo coativamente no mundo da produção manufatureira. ${ }^{22}$ - Grifo Nosso.

Nessa lógica se justifica, levando em conta as transformações políticas, econômicas e sociais que ocorriam, como já mencionado em

\footnotetext{
${ }^{19}$ DEL OLMO, Rosa. A América Latina e sua criminologia. Tradução: Francisco Eduardo Pizzolante e Sylvia Moretzsohn. 1.ed. Vol. 9 - Coleção Pensamento Criminológico. São Paulo: Editora Revan, 2004. Capítulo I - O surgimento da criminologia como ciência, p. 46.

${ }^{20}$ DAHL, Tove Sang. La intervención estatal y el control social en la Europa del siglo XIX. In: II Conferência do Grupo Europeu para o Estudo do Desvio e Controle Social. Essex, Inglaterra, 1974, p. 34.

${ }^{21}$ FOUCAULT, Michel. Historia de la locura en la época clásica. Tradução: Juan José Utrilla. 1.ed. em Espanhol. México: Editora Fondo de Cultura Económica, 1967, p. 55.

${ }^{22}$ MELOSSI, Dario; PAVARINI, Massimo. Cárcel y fábrica: los orígenes del penitenciarismo. Siglos XVI-XIX. 2.ed. México: Siglo XXI, 1985, p. 42.
} 
parágrafos pregressos, ganhar força, nessa época, o instituto denominado por Foucault como "mitigação das penas"23: consiste tanto na especificação das penalidades como nas suas consequentes aplicações de maneira proporcional e razoável, tendo em vista a gravidade e complexidade dos crimes cometidos. Trata-se de um sistema penal cujo objetivo é encontrar o castigo correspondente para cada delito de forma determinada. Segundo o autor:

Para ser útil, o castigo deve ter como objetivo as consequências do crime, entendidas como a série de desordens que este é capaz de abrir. A proporção entre a pena e a qualidade do delito é determinada pela influência que o pacto violado tem sobre a ordem social. ${ }^{24}$ - Grifo Nosso.

Torna-se, então, necessária a construção de um "novo arsenal de penas" 25 , com condições a que se deve obedecer para que toda a eficácia do sistema seja garantida. Seguindo nessa mesma perspectiva, como já referenciado, posiciona-se Cesare Beccaria:

Os castigos têm por finalidade única obstar o culpado de tornar-se futuramente prejudicial à sociedade e afastar os seus concidadãos do caminho do crime. Entre as penalidades e no modo de aplicá-las proporcionalmente aos delitos, é necessário, portanto, escolher os meios que devem provocar no espírito público a impressão mais eficaz e mais durável e, igualmente, menos cruel no corpo do culpado. ${ }^{26}$ - Grifo Nosso.

Dessa maneira, observa-se, mesmo que de forma incipiente, o instituto da individualização da pena - princípio constitucionalmente assegurado no ordenamento jurídico brasileiro atual - em que o condenado deve receber a sanção exata e justa para a sua situação específica, ou seja, é preciso adequar a punição imposta às circunstâncias e peculiaridades de cada caso.

Tem que haver relações exatas entre a natureza do delito e a natureza da punição; aquele que foi feroz em seu crime sofrerá dores físicas; aquele que tiver sido preguiçoso será obrigado a um trabalho penoso; aquele que foi abjeto sofrerá uma pena de infâmia. ${ }^{27}$ - Grifo Nosso.

\footnotetext{
${ }^{23}$ FOUCAULT, Michel. Vigiar e punir: nascimento da prisão. Tradução: Raquel Ramalhete. 42.ed. Petrópolis: Editora Vozes, 2014. Segunda Parte: Punição, Capítulo II - A mitigação das penas, p. 102.

${ }^{24}$ FOUCAULT, Michel. Vigiar e punir: nascimento da prisão. Tradução: Raquel Ramalhete. 42.ed. Petrópolis: Editora Vozes, 2014. Segunda Parte: Punição, Capítulo I - A punição generalizada, p. 91. ${ }^{25}$ FOUCAULT, Michel. Op. cit., loc. cit.

${ }^{26}$ BECCARIA, Cesare. Dos delitos e das penas. Tradução: Torrieri Guimarães. 7.ed. São Paulo: Editora Martin Claret Ltda., 2013. Capítulo XV, Da moderação das penas, p. 45.

27 SAINT-FARGEAU, Le Peletier de. Archives parlementaires. T. XXVI, p. 321s. Apud FOUCAULT, Michel. Vigiar e punir: nascimento da prisão. Tradução: Raquel Ramalhete. 42.ed. Petrópolis: Editora Vozes, 2014. Segunda Parte: Punição, Capítulo I - A punição generalizada, p. 99.
} 
Nota-se, ainda, que para a determinação da pena a ser aplicada consideram-se não apenas as circunstâncias fáticas do delito praticado como também as características pessoais do autor que o praticou. Como bem alude Foucault:

Um mesmo castigo não tem a mesma força para todo mundo; a multa não é temível para o rico, nem a infâmia a quem já está exposto. A nocividade de um delito e seu valor de indução não são os mesmos, de acordo com o status do infrator; o crime de um nobre é mais nocivo para a sociedade que o de um homem do povo. Enfim, já que o castigo quer impedir a reincidência, ele tem que levar bem em conta o que é o criminoso em sua natureza profunda, o grau presumível de sua maldade, a qualidade intrínseca de sua vontade. ${ }^{28}$ - Grifo Nosso.

No mesmo sentido, inclusive, versa Jean-Paul Marat:

De dois homens que cometeram o mesmo crime, em que proporção é menos culpado aquele que mal tinha o necessário com relação àquele a quem sobrava $o$ supérfluo? De dois perjuros, em que medida é mais criminoso aquele em que se procurou, desde a infância, imprimir sentimentos de honra com relação àquele que, abandonado à natureza, nunca recebeu educação ${ }^{29}$ - Grifo Nosso.

Todos esses preceitos foram sementes que germinaram e influenciaram o processo de codificação e compilação das leis em diversos países e, assim, se perpetuaram no tempo. Importante colocar, inclusive, em nível meramente ilustrativo, que, muito embora vigore na legislação brasileira o Direito Penal do Fato, há resquícios do Direito Penal do Autor no procedimento trifásico de fixação da pena: conforme se verifica no disposto no artigo 59 do Código Penal Brasileiro ${ }^{30}$, em que se encontram previstas as circunstâncias judiciais - diretrizes individualizantes para a determinação da pena-base.

\footnotetext{
${ }^{28}$ FOUCAULT, Michel. Vigiar e punir: nascimento da prisão. Tradução: Raquel Ramalhete. 42.ed. Petrópolis: Editora Vozes, 2014. Segunda Parte: Punição, Capítulo I - A punição generalizada, p. 97. ${ }^{29}$ MARAT, Jean-Paul. Plan de législation criminelle. Neuchâtel, 1780, p. 34.

${ }^{30}$ Decreto-Lei 2.848/40, art. 59 - O juiz, atendendo à culpabilidade, aos antecedentes, à conduta social, à personalidade do agente, aos motivos, às circunstâncias e consequências do crime, bem como ao comportamento da vítima, estabelecerá, conforme seja necessário e suficiente para reprovação e prevenção do crime:

I - as penas aplicáveis dentre as cominadas;

II - a quantidade de pena aplicável, dentro dos limites previstos;

III - o regime inicial de cumprimento da pena privativa de liberdade;

IV - a substituição da pena privativa da liberdade aplicada, por outra espécie de pena, se cabível.
} 
A proposta de mitigação das penas, por sua vez, enseja o surgimento de modelos de encarceramento punitivo que se tangenciam na busca de um mesmo objetivo-fim: a reconstrução do "homo economicus" 31 , pois se partia do pressuposto de que a maior parte dos crimes tinha como causa a ociosidade. Como bem narra Foucault:

Essa pedagogia tão útil reconstituirá no indivíduo preguiçoso o gosto pelo trabalho, recolocá-lo-á por força num sistema de interesses em que o trabalho será mais vantajoso que a preguiça, formará em torno dele uma pequena sociedade reduzida, simplificada e coercitiva onde aparecerá claramente a máxima: quem quer viver tem que trabalhar. Obrigação do trabalho, mas também retribuição que permite ao detento melhorar seu destino durante e depois da detenção. $\mathrm{O}$ homem que não encontra sua subsistência deve absolutamente ser levado ao desejo de procurá-la pelo trabalho; ela lhe é oferecida pela polícia e pela disciplina; de alguma maneira, ele é obrigado a se entregar; a atração do ganho o excita, em seguida: corrigido em seus hábitos, acostumado a trabalhar, alimentado sem inquietação com alguns lucros que reserva para a saída [ele aprendeu uma profissão] que lhe garante uma subsistência sem perigo. ${ }^{32}$ - Grifo Nosso.

Diante de todo o exposto, inegável é a forte ingerência e condicionamento da estrutura econômica na prisão-sanção em relação tanto à sua formação como também às suas finalidades. Desde já, então, resta claro como tal vinculação muito dificulta a efetividade dos propósitos reformistas - mencionados anteriormente - normalmente atribuídos à pena privativa de liberdade, obstáculo esse muito bem ilustrado nas palavras, que se seguem, de Cezar Roberto Bitencourt:

É interessante apontar que a vinculação da prisão à necessidade de ordem econômica, que inclui a dominação da burguesia sobre o proletariado, dito em termos muito esquemáticos, faz surgir a tese de que é um mito pretender ressocializar o delinquente por meio da pena privativa de liberdade. ${ }^{33}-$ Grifo Nosso.

\footnotetext{
${ }^{31}$ FOUCAULT, Michel. Vigiar e punir: nascimento da prisão. Tradução: Raquel Ramalhete. 42.ed. Petrópolis: Editora Vozes, 2014. Segunda Parte: Punição, Capítulo II - A mitigação das penas, p. 121.

${ }^{32}$ Ibid., p. 120.

${ }^{33}$ BITENCOURT, Cezar Roberto. Tratado de Direito Penal - Parte Geral 1. 19.ed. São Paulo: Editora Saraiva, 2013. Terceira Parte, Capítulo XXVIII, História e Evolução da Pena de Prisão, p. 592.
} 


\section{CAPÍTULO 2. PRISONIZAR PARA SOBREVIVER}

\subsection{O VÉU DA LEGALIDADE}

No capítulo anterior, restaram claros a constituição e o fundamento do direito de punir com a formação do Estado a partir do pacto social. Nas lições de Beccaria, afirma-se que:

A primeira consequência que se tira desses princípios é que apenas as leis podem indicar as penas de cada delito e que o direito de estabelecer leis penais não pode ser senão da pessoa do legislador, que representa toda a sociedade ligada por um contrato social. ${ }^{34}$ - Grifo Nosso.

Essencial se faz dizer que Beccaria foi um grande contestador da ordem social e judicial arbitrária vigente na sua época. Imbuído de valores iluministas, é considerado o pai do direito criminal moderno, por preconizar a humanização das ciências penais, rompendo assim com o direito penal da crueldade. Em seu discurso, perceptível é uma forte influência das formulações de Montesquieu quanto à divisão do poder em executivo, legislativo e judiciário: poderes esses que se autorregulam, uma vez que o exercício de um deles limita a atuação dos demais de maneira recíproca. Foi a partir desse pressuposto - de que cada poder possui a sua função típica que Montesquieu fundamentou serem os juízes apenas "a boca que pronuncia as palavras da lei" ${ }^{35}$. Guiado por essas concepções, Beccaria sustenta:

Não há nada mais perigoso do que o axioma comum, de que é necessário consultar o espírito da lei. Adotar esse axioma é quebrar todos os diques e abandonar as leis à torrente das opiniões. (...) Quando as leis forem fixas e literais, quando apenas confiarem ao magistrado a missão de examinar os atos dos cidadãos, para indicar se esses atos são conformes à lei escrita, ou se a contrariam; quando, finalmente, a regra do justo e do injusto, que deve orientar em todos os seus atos o homem sem instrução e o instruído, não constituir motivo de controvérsia, porém simples questão de fato, então não se verão mais os cidadãos submetidos ao poder de uma multidão de ínfimos tiranos. ${ }^{36}$ - Grifo Nosso.

\footnotetext{
${ }^{34}$ BECCARIA, Cesare. Dos delitos e das penas. Tradução: Torrieri Guimarães. 7.ed. São Paulo: Editora Martin Claret Ltda., 2013. Capítulo III, Consequências desses princípios, p. 18.

${ }^{35}$ MONTESQUIEU, Charles Louis de Secondat, Baron de la Brède e de. O Espírito das Leis. Tradução: Pedro Vieira Mota. 9.ed. São Paulo: Martins Fontes, 2008, p. 171.

${ }^{36}$ BECCARIA, Cesare. Op. cit., Capítulo IV, Da interpretação das leis, p. 20-21.
} 
A proposta desse jurista italiano é de que cada crime merece uma pena proporcional ao dano causado, ou seja, de que as punições devem ser justas - o que, por sua vez, ocorre pela aplicação literal das penalidades pré-fixadas pela lei -; ataca, dessa forma, o caráter seletivo e segregacionista do sistema penal como um todo.

Assim como é certo que a pretensão punitiva pertence ao Estado, com a vedação à autotutela, nítida também se faz a ineficácia do complexo penitenciário para os objetivos aos quais, teoricamente, se propõe. Como já aludido no capítulo anterior, estes se resumem em um tripé composto pelas seguintes ramificações: retribuição, prevenção e ressocialização. A falência da privação de liberdade como sanção não se restringe à sua aplicação em si, ou seja, não se resume ao momento da execução. A flagrante ruína do sistema carcerário evidencia a utopia dos discursos penais socialmente legitimados pelo chamado véu da legalidade. A verdade, como bem assinala Eugenio Raúl Zaffaroni em seu livro Em busca das penas perdidas, é que "o sistema penal é uma complexa manifestação do poder social" ${ }^{37}$, percepção essa também sentida por Cesare Beccaria ao propor que

Percorramos a História e constataremos que as leis, que deveriam constituir convenções estabelecidas livremente entre homens livres quase sempre não foram mais do que o instrumento das paixões da minoria, ou fruto do acaso e do momento e nunca a obra de um prudente observador da natureza humana, que tenha sabido orientar todas as ações da sociedade com esta finalidade única: todo o bemestar possível para a maioria. ${ }^{38}$ - Grifo Nosso.

Muito embora as críticas formuladas por Beccaria estejam voltadas para a sociedade da segunda metade do século XVIII, suas apreciações continuam bastante atuais, considerando-se o engendramento das sociedades modernas. A ilegitimidade do sistema penal acaba por ser maquiada pelo véu da legalidade, ensejando uma falsa percepção de legitimidade, visto que não

\footnotetext{
${ }^{37}$ ZAFFARONI, Eugenio Raúl. Em busca das penas perdidas: a perda da legitimidade do sistema penal. Tradução: Vânia Romano Pedrosa e Amir Lopes da Conceição. 5.ed. Rio de Janeiro: Editora Revan, 1991. CAPÍTULO PRIMEIRO, A situação crítica do penalismo latino-americano, Legitimidade e Legalidade, p. 16.

${ }^{38}$ BECCARIA, Cesare. Dos delitos e das penas. Tradução: Torrieri Guimarães. 7.ed. São Paulo: Editora Martin Claret Ltda., 2013. Capítulo XV, Da moderação das penas, p. 45.
} 
passa de mera ilusão. Zaffaroni, quando analisa mais especificamente a situação crítica do penalismo latino-americano, atenta para o fato de que

O sistema penal não atua de acordo com a legalidade. A operacionalidade real do sistema penal seria "legal" se os órgãos que para ele convergem exercessem seu poder de acordo com a programação legislativa tal como a expressa o discurso jurídico-penal. ${ }^{39}$ - Grifo Nosso.

Um dos famosos caminhos, muito utilizado, para burlar essa legalidade estrita, defendida pelos filósofos pertencentes a esse movimento humanitário - no qual, como já mencionado, se insere Beccaria -, é " $a$ proliferação de tipificações com limites difusos e elementos valorativos moralistas" 40 , posto que confere uma subjetividade; o que, por sua vez, abre margem para um exercício arbitrário por parte das agências penais. Certo é que, se todos os crimes expressamente previstos no ordenamento jurídico fossem, de forma concreta, perseguidos pelos órgãos estatais, "praticamente não haveria habitante que não fosse, por diversas vezes, criminalizado"41. Em razão disso, Zaffaroni expõe justamente que,

Diante da absurda suposição - não desejada por ninguém - de criminalizar reiteradamente toda a população, torna-se óbvio que o sistema penal está estruturalmente montado para que a legalidade não opere e, sim, para que exerça seu poder com altíssimo grau de arbitrariedade seletiva dirigida, naturalmente, aos setores vulneráveis (...). Os órgãos legislativos, inflacionando as tipificações, não fazem mais do que aumentar o arbítrio seletivo dos órgãos executivos do sistema penal e seus pretextos para o exercício de um maior poder controlador. $^{42}$ - Grifo Nosso.

Seguindo a mesma vertente, Beccaria patenteia que esse inchaço penal segregador - uma vez que visa a atender as vontades e os desejos das classes dominantes - é um meio falho e ineficaz para prevenir crimes.

É preferível prevenir os delitos a ter de puni-los; e todo legislador sábio deve antes procurar impedir o mal que repará-lo (...). Se são proibidos aos cidadãos muitos atos indiferentes, atos os quais nada têm de prejudicial, não se previnem os delitos: em vez disso, faz-se que apareçam novos, pois se mudam de modo arbitrário as ideias comuns de vício e de virtude, que ainda se proclamam eternas e imutáveis

\footnotetext{
${ }^{39}$ ZAFFARONI, Eugenio Raúl. Em busca das penas perdidas: a perda da legitimidade do sistema penal. Tradução: Vânia Romano Pedrosa e Amir Lopes da Conceição. 5.ed. Rio de Janeiro: Editora Revan, 1991. CAPÍTULO PRIMEIRO, A situação crítica do penalismo latino-americano, Legitimidade e Legalidade, p. 21.

${ }^{40}$ Ibid., p. 28.

${ }^{41}$ Ibid., p. 26.

${ }^{42}$ Ibid., p. 27.
} 
(...). Ora, quanto mais se estender a esfera dos delitos, tanto mais se fará que sejam praticados, pois se verão os crimes aumentarem à proporção que as razões de crimes especificados pelas leis forem mais numerosas, especialmente se a maioria de tais leis não for mais do que privilégios de um pequeno número de senhores. Desejais prevenir os crimes? Fazei leis simples e claras; e esteja o país inteiro preparado a armar-se para defendê-las, sem que a minoria de que falamos se preocupe constantemente em destruí-las. Que elas não favoreçam qualquer classe em especial; protejam igualmente cada membro da sociedade; tema-as o cidadão e trema apenas diante delas. O temor que as leis inspiram é saudável, o temor que os homens inspiram é uma fonte nefasta de delitos. ${ }^{43}$ - Grifo Nosso.

Importante mencionar neste momento, ainda no que concerne a esse aspecto seletivo já referenciado, a entrevista concedida por Hélio Luz, quando era chefe da Polícia Civil, ao documentário brasileiro, datado de 1999, Notícias de uma Guerra Particular, cujo pano de fundo é a dinâmica do tráfico nas favelas do Rio de Janeiro e a consequente violência emergente do embate entre policiais e traficantes. Hélio reconhece a corrupção da polícia (instituição integrante do sistema penal - uma agência penal), mas questiona até que ponto a sociedade demanda uma atuação policial não corrupta:

A polícia é uma instituição que foi criada para ser violenta e corrupta porque ela foi feita para fazer a segurança de Estado e a segurança da elite. A polícia é política mesmo, estamos em uma sociedade injusta e a polícia garante essa sociedade injusta. $\mathrm{O}$ excluído fica sob controle e ai dele que saia disso. É bem sofisticado porque no Apartheid da África do Sul colocavam arame e aqui é sem arame: não pode reclamar e não pode deixar de pagar imposto (...). A política de segurança que se pratica aqui é eficiente. O questionamento agora é o seguinte: a sociedade quer uma polícia que não seja corrupta? Já trabalhei em uma equipe com 30 homens que não levavam grana da população em uma cidade do interior. Os dois primeiros meses foram ótimos porque o carcereiro-chefe tinha tomado conta da boca de fumo da cidade, então a cidade estava em pânico. Aplausos durante dois meses. No terceiro mês, o segurança do dono do supermercado deu um tapa em um garoto que estava roubando uma garrafa de cachaça: foi autuado o garoto e foi autuado o segurança. O dono do supermercado veio argumentar: "mas, doutor, é um ladrão!", e eu disse que "não pode! O segurança não pode bater no ladrão"; foram autuados os dois. A partir daí os clubes de serviço não me convidavam mais para os jantares de quarta-feira. Pouco tempo depois, um fazendeiro praticou um homicídio e foi autuado: pronto, encrencou; o que era bom já deixou de ser. Então, se coloca para a sociedade: há interesse em ter uma polícia que não seja corrupta? Porque uma polícia que não é corrupta é aquela que multa todos que param em local proibido ou que avançam o sinal; aquela que atua na favela e no Posto 9. Com uma polícia não corrupta vai ter que parar de cheirar em Ipanema; terá mandado de segurança e pé na porta na Delfim Moreira porque essa polícia não

\footnotetext{
${ }^{43}$ BECCARIA, Cesare. Dos delitos e das penas. Tradução: Torrieri Guimarães. 7.ed. São Paulo: Editora Martin Claret Ltda., 2013. Capítulo XLI, Dos meios de prevenir crimes, p. 94-95.
} 
segrega, não seleciona, não limita: a sociedade vai conseguir segurar isso ${ }^{44}$ Grifo Nosso.

Isto posto, resta claro concluir que "o sistema penal é um verdadeiro embuste: pretende dispor de um poder que não possui, ocultando o verdadeiro poder que exerce" ${ }^{45}$, ou seja, está-se diante de um sistema estruturalmente seletivo falseado por um discurso de legalidade e, por conseguinte, ilegítimo.

\subsection{AS CONTRADIÇÕES DA PENA PRIVATIVA DE LIBERDADE E A CONSEQUENTE PRISONIZAÇÃO FORMULADA POR AUGUSTO THOMPSON}

Como já assinalado em páginas anteriores, mas se faz necessária a repetição para o desencadeamento deste trabalho, oficialmente a pena privativa de liberdade se propõe, concomitantemente, a três objetivos: (1) retribuir o mal causado; (2) prevenir a prática de novos delitos, tanto em uma perspectiva geral - pois serve de exemplo para a sociedade como um todo - como também em um aspecto especial por meio da intimidação ao infrator; e (3) ressocializar o preso no sentido de readaptá-lo à vida em sociedade. Em função disso Augusto Thompson introduz seu livro A Questão Penitenciária - resultado de um trabalho de campo no qual o autor realizou inúmeras visitas ao ambiente carcerário - que o sistema prisional carrega, em seu bojo, "a sina do autofracasso" 46 .

Punir é castigar, fazer sofrer. Para punir um homem retributivamente é preciso injuriá-lo. A intimidação, a ser obtida pelo castigo, demanda que este seja apto a causar terror. Ora, tais condições são reconhecidamente impeditivas de levar ao sucesso uma ação pedagógica, pois para reformar um homem é preciso

\footnotetext{
${ }^{44}$ NOTÍCIAS de uma Guerra Particular. Direção: João Moreira Salles e Kátia Lund. Produção: Raquel Freire Zangrandi. Música: Antonio Pinto. Intérpretes: Rodrigo Pimentel, Paulo Lins, Itamar Silva, Nilton Cerqueira, Carlos Luis Gregório, Hélio Luz e outros. Roteiro: João Moreira Salles e Kátia Lund. BRETZ FILMES. 1999. 57 min. Trecho: 29min26s-32min53s.

${ }^{45}$ ZAFFARONI, Eugenio Raúl. Em busca das penas perdidas: a perda da legitimidade do sistema penal. Tradução: Vânia Romano Pedrosa e Amir Lopes da Conceição. 5.ed. Rio de Janeiro: Editora Revan, 1991. CAPÍTULO PRIMEIRO, A situação crítica do penalismo latino-americano, Legitimidade e Legalidade, p. 26.

${ }^{46}$ THOMPSON, Augusto. A questão penitenciária. 2.ed. Rio de Janeiro: Editora Forense, 1980. Parte I - Irrecuperação Penitenciária, Capítulo I, Introdução, p. 2.
} 
melhorá-lo e os homens não são melhoráveis através das injúrias. - Grifo Nosso. ${ }^{47}$

Dessa forma, evidente é a incompatibilidade latente entre a função punitiva de caráter retributivo e a atividade terapêutica direcionada para a regeneração do apenado, o que justifica "o insucesso da pena carcerária recuperadora" 48 diante de tal conflito. Deflagra-se, assim, um antagonismo de objetivos tão significativo, que equilibrá-los se demonstra inviável, como é possível perceber em uma formulação de David Dressler:

O sistema prisional procede numa direção muito incerta, porque sua administração tem, necessariamente, uma série de compromissos. De um lado, espera-se que as prisões punam; de outro, supõe-se que reformem. Espera-se que disciplinem rigorosamente ao mesmo tempo em que ensinem a autoconfiança. São construídas para operar como grandes máquinas impessoais, mas se espera que ajustem os homens a viver vidas comunitárias normais. Operam de acordo com uma rígida rotina autocrática, mas se espera que desenvolvam a iniciativa individual. Todas as regras restritivas, por demais frequentes, obrigam o preso à ociosidade, a despeito do fato de que um dos seus objetivos primários é ensinar aos homens como ganhar uma vida honesta. Recusam ao preso qualquer possibilidade de autogoverno, mas esperam que ele se transforme em um homem consciente numa sociedade democrática. Para alguns, as prisões não são mais do que clubes campestres, a prover as fantasias e os caprichos dos internos. Para outros, a atmosfera prisional parece carregada somente de amargura, de rancor e de sentimento pervertido de frustração. E assim o esquema paradoxal prossegue, porque nossas ideias a respeito da função das instituições correcionais, na nossa sociedade, são confusas, vagas e nebulosas. ${ }^{49}$

É possível aferir, a partir do excerto supracitado, que o senso comum da comunidade livre - que, inclusive, muito interfere na dinâmica de funcionamento do complexo penitenciário - preza, em seu inconsciente, pelo imperativo da punição, para que "a justiça seja feita"50 ou para que "haja vingança" ${ }^{51}$, razão pela qual, há, em sua maioria, maior indignação social quando, por exemplo, (1) é concedido a um condenado de um crime bárbaro uma visita ao lar em datas festivas ou quando ocorrem (2) mortes e fugas

\footnotetext{
${ }^{47}$ THOMPSON, Augusto. A questão penitenciária. 2.ed. Rio de Janeiro: Editora Forense, 1980. Parte I - Irrecuperação Penitenciária, Capítulo II, Fins Contraditórios Atribuídos à Pena de Prisão, METAS FORMAIS CONFLITANTES, p. 6.

${ }^{48}$ THOMPSON, Augusto. A questão penitenciária. 2.ed. Rio de Janeiro: Editora Forense, 1980. Prefácio da 1.ed., p. XIV.

${ }^{49}$ DRESSLER, David. Readings in Criminology and Penology. 2.ed. Columbia University Press, 1948. Annual Report, Federal Bureau of Prisions, p. 593-594.

${ }^{50}$ Expressão popular.

${ }^{51}$ Expressão popular.
} 
resultantes de algum tipo de rebelião intramuros, do que o alto índice de reincidência. Como bem expõe Augusto Thompson:

Observa-se a repetição frequente da recidiva, por parte daqueles que cumpriram pena, representada, às vezes, pelo retorno ao cárcere de pessoas que mal saíram dele. Trata-se de prova manifesta de que a instituição falhou nos objetivos, sobretudo no que atende à intimidação e à recuperação. Entretanto, a constatação do fato não oferece ensejo a reações perceptíveis por parte da população. Pelo contrário, a reentrada de ex-convictos na prisão, de que se tem notícia a todo o momento, é fenômeno assimilado de maneira bastante tranquila, não chegando, sequer, a arranhar a sensibilidade social. ${ }^{52}-$ Grifo Nosso.

Por esse motivo, existe uma preocupação da direção carcerária em "manter em rigorosa disciplina a comunidade carcerária para prevenir evasões e desordens" ${ }^{\prime 53}$, o que, conforme já supracitado, acaba por podar o desenvolvimento do preso em seu processo de reformação. Desse modo, " $o$ encorajamento do autorrespeito, do senso de responsabilidade, da autoconfiança, do espírito de independência e de criatividade" ${ }^{54}$ é esmagado pela concretização de um ideal de segurança. Em Memórias do cárcere, Graciliano Ramos descreve esse "completo sacrificio de autonomia" 55 a partir de um "controle ilimitado sobre o preso" 56.

Esse automatismo, renovado com frequência nas cadeias, é uma tortura; as pessoas livres não imaginam a extensão do tormento. Certo, há uma razão para nos mexermos desta ou daquela maneira, mas, desconhecendo o móvel dos nossos atos, andamos à-toa, desarvorados. Roubaram-nos completamente a iniciativa, os nossos desejos, os intuitos mais reservados estão sujeitos à verificação; e forçamnos a procedimento desarrazoado. ${ }^{57}$ - Grifo Nosso.

Assim, de acordo com essas diretrizes, conclui Augusto Thompson que:

Tal é o grau de importância emprestado a esses meios, tidos como os únicos côngruos para atingir as metas propostas, que a sociedade os eleva a uma posição de prevalência, relativamente aos próprios fins - ou seja: os meios transformam-

\footnotetext{
52 THOMPSON, Augusto. A questão penitenciária. 2.ed. Rio de Janeiro: Editora Forense, 1980. Parte I - Irrecuperação Penitenciária, Capítulo II, Fins Contraditórios Atribuídos à Pena de Prisão, METAS INFORMAIS - TESTILHA COM O ALVO REGENERAÇÃO, p. 9.

${ }^{53}$ Ibid., p. 10.

${ }^{54}$ Ibid., p. 11.

${ }^{55}$ THOMPSON, Augusto. A questão penitenciária. 2.ed. Rio de Janeiro: Editora Forense, 1980. Parte I - Irrecuperação Penitenciária, Capítulo III, O Sistema Social da Prisão, OS PRESOS, p. 59.

${ }^{56}$ Ibid., p. 60.

${ }^{57}$ RAMOS, Graciliano. Memórias do cárcere. 1.ed. $1^{\circ}$ vol. Brasil: Editora José Olympio, 1953, p. 150.
} 
se em fins e, mais, em fins prioritários. Disso resulta que os controles informais do mundo livre dirigem-se, predominantemente, no sentido de fiscalizar a satisfação dos alvos (nominalmente meios) segurança e disciplina, ao mesmo passo em que afrouxam no que tange aos objetivos oficialmente reconhecidos. ${ }^{58}$ - Grifo Nosso.

Além da nítida incongruência das finalidades da pena de prisão, verifica-se ainda outro paradoxo: o antinomismo dos vetores predominantes no extramuros e no intramuros da penitenciária. Qualquer ambiente em que se tenha um grupo de pessoas interagindo acaba configurando uma célula social. A grande questão é que, em concordância com as análises de Augusto Thompson:

A cadeia não é uma miniatura da sociedade livre, mas um sistema peculiar. Um regime interno próprio, informal, resultante da interação concreta dos homens, diante dos problemas postos pelo ambiente particular em que se viram envolvidos. ${ }^{59}$ - Grifo Nosso.

A respeito dessas divergências quanto aos moldes de cada comunidade - a carcerária e a livre - Dennis Chapman elabora a seguinte contraposição:

Na vida civil, o cidadão é, geralmente, membro de uma família, de um grupo laboral, de um grupo de vizinhança, de uma comunidade local, que apresentam grande variação de interesses grupais, uma variação completa de idade e uma variedade infinita de ligações sociais. A maioria dos adultos tem relações sóciosexuais de um padrão permanente, contínuo e, usualmente, heterossexuais. $\mathrm{Na}$ prisão, em contraste, as relações sociais são temporárias (pela duração da sentença) e compulsórias (geralmente, baseadas na residência numa cela, bloco de celas, ou pátio e no local de trabalho, embora em algumas prisões os interesses grupais possam desenvolver-se). A variação de idade é estreita e as relações sócio-sexuais são, exclusivamente, homossexuais. O sistema padrão da sociedade civil é baseado no lucro, ocupação, educação e participação nos assuntos comunitários. Muito pouco disso existe no sistema prisional. ${ }^{60}$

Dessa maneira, verifica-se que "a penitenciária é uma sociedade dentro de uma sociedade uma vez que nela foram alteradas, drasticamente, numerosas feições da comunidade livre" ${ }^{1}$, de modo que a "adaptação à

\footnotetext{
${ }^{58}$ THOMPSON, Augusto. A questão penitenciária. 2.ed. Rio de Janeiro: Editora Forense, 1980. Parte I - Irrecuperação Penitenciária, Capítulo II, Fins Contraditórios Atribuídos à Pena de Prisão, METAS INFORMAIS - TESTILHA COM O ALVO REGENERAÇÃO, p. 9.

${ }^{59}$ THOMPSON, Augusto. A questão penitenciária. 2.ed. Rio de Janeiro: Editora Forense, 1980. Parte I - Irrecuperação Penitenciária, Capítulo III, O Sistema Social da Prisão, IDEIAS GERAIS, p. 21.

${ }^{60}$ CHAPMAN, Dennis. Sociology and the Stereotyps of the Criminal. Londres: Tavistock Publ., 1968, p. 201.

${ }^{61}$ SYKES, Gresham M. The Society of Captives. New Jersey: Princeton University Press, 1972, p. 12.
} 
prisão implica em (sic) desadaptação à vida livre" ${ }^{62}$; ou seja, em uma analogia metafórica, utilizada pelo criminólogo Riccardo Cappi, "se ensina a nadar em uma piscina sem água" ${ }^{\prime 63}$. Em seu livro A questão penitenciária, uma das principais referências bibliográficas deste trabalho, Thompson relata um diálogo travado entre ele e o promotor Silveira Lobo, em uma solenidade festiva, sobre um interno da Penitenciária Lemos Brito, que servia como garçom no evento, acerca da "capacidade regeneradora da prisão"64.

- É, parece que este homem está, mesmo, recuperado.

Silveira Lobo demorou-se um pouco, seguindo com a vista o interno, objeto do comentário. Depois, soltou vagarosamente:

- É... Está muito diferente do menino que conheci logo que caiu nas mãos da Justiça. Engordou, exibe formas arredondadas; os olhos estão meio baços e, em geral, fitam o chão; curva-se com bastante servilidade diante das pessoas; a voz mostra um certo acento feminino; move-se com lentidão, cuidadosamente, quase diria com receio; formalmente respeitoso, parece preocupado em, por qualquer distração, deixar de cumprir algum comando regulamentar; na pequena conversa que teve com você, sugeriu uma intriga envolvendo um guarda e um companheiro. É... daquele jovem atrevido, enérgico, topetudo, independente, altivo, não restou nada.

E terminou, com triste ironia:

- Foi uma bela regeneração... ${ }^{65}$ - Grifo Nosso.

Percebe-se, portanto, que a cadeia modifica completamente o indivíduo. Tal fenômeno é denominado por Augusto Thompson como "efeitos da prisonização"66 - e será analisado com maior profundidade mais adiante nesta monografia. $\mathrm{O}$ interno que permanece em cárcere por um período de tempo prolongado acaba por enraizar, dentro de si, os moldes da vida prisional, de modo que não consegue mais viver do outro lado dos muros da prisão.

\footnotetext{
${ }^{62}$ THOMPSON, Augusto. A questão penitenciária. 2.ed. Rio de Janeiro: Editora Forense, 1980. Parte I - Irrecuperação Penitenciária, Capítulo II, Fins Contraditórios Atribuídos à Pena de Prisão, ATRITO ENTRE ADAPTAÇÃO À PRISÃO E READAPTAÇÃO À VIDA LIVRE, p. 14.

${ }^{63}$ CAPPI, Ricardo. In: PROGRESSÃO de pena funciona mal por que é falha ou por que o estado não atende às exigências da lei?. Direção: Marcelo Canellas. Produção: Vera Souto. Edição: Joelson Maia. Técnicos: Paulo Martins e Jorge Sant'anna. Arte: Alexandre Beltran. Imagem: Lúcio Alves. FANTÁSTICO. REDE GLOBO. 6 dez. 2015. 15min47s. Disponível em: <http://g1.globo.com/fantastico/noticia/2015/12/fantastico-ouve-especialistas-e-vitimas-sobreprogressao-de-pena.html>. Acesso em: 13 set. 2017. Trecho: 5min50s-6min02s.

${ }^{64}$ THOMPSON, Augusto. Op. cit., loc. cit.

${ }^{65}$ Ibid., p. 15.

${ }^{66}$ THOMPSON, Augusto. A questão penitenciária. 2.ed. Rio de Janeiro: Editora Forense, 1980. Parte I - Irrecuperação Penitenciária, Capítulo III, O Sistema Social da Prisão, IDEIAS GERAIS, p. 26.
} 
Essa transformação é bem ilustrada no filme Um Sonho de Liberdade - uma produção estadunidense - quando o detento Brooks Hatlen, um dos mais antigos e o curador da biblioteca da penitenciária Shawshank, ameaça outro preso com uma faca no pescoço ao saber que sairá em livramento condicional. Indignados com o ocorrido, os prisioneiros ficaram sem entender o que aconteceu, concluindo, por conseguinte, que Brooks havia enlouquecido. No entanto, Ellis "Red" Redding - detento interpretado por Morgan Freeman - elucida que:

Brooks não é maluco, só ficou institucionalizado. Ele está aqui há 50 anos. É tudo que ele conhece. Aqui ele é um homem importante, é um homem culto. Lá fora ele não é nada, só um ex-presidiário com artrite nas duas mãos, talvez nem consiga tirar um cartão da biblioteca (...). Esses muros são traiçoeiros: primeiro a gente odeia, depois se acostuma e, depois de muito tempo, você fica dependente. Isso é que é institucionalizado. Fique o mesmo tempo que o Brooks ficou aqui. Nos mandam viver aqui e é exatamente o que nos tiram, a parte que conta pelo menos. ${ }^{67}$ - Grifo Nosso.

Fato é que Brooks não se adapta à vida apressada do mundo livre e, cansado de viver com medo, tira a sua própria vida. Em um relato semelhante, porém agora se tratando de uma história real, Carlos Raymundo Cardoso que chegou, inclusive, a ser diretor da penitenciária Lemos Brito - relata sua experiência com o preso Fidelis, quando o representou como defensor público:

Fidelis era um preso velho, antigo, veio condenado naqueles homicídios brabos de interior por meter a foice em alguém. Era um preso excelente, bem-comportado, adaptado à cadeia. Como defensor público, na época, lutei para que fosse concedido o livramento condicional. Ele acabou saindo com o dinheiro do pecúlio e regressou para sua cidade. Chegando lá, não encontrou mais família, não encontrou mais amigos, não conhecia mais ninguém. Voltou para Niterói, mas não conseguia emprego; de vez em quando ia na penitenciária para pedir comida. Um dia, em uma dessas apresentações periódicas do livramento, colocou uma arma na cintura e se apresentou armado. O juiz imediatamente o prendeu, cassou o livramento e Fidelis voltou para a cadeia que era exatamente o que ele queria, pois não conseguia mais viver fora da prisão. ${ }^{68}$ - Grifo Nosso.

\footnotetext{
67 SONHO de Liberdade, Um. Direção: Frank Darabont. Produção: Niki Marvin. Produção executiva: Liz Glotzer e David V. Lester. Intérpretes: Tim Robbins, Morgan Freeman e outros. Roteiro: Frank Darabont. Castle Rock Entertainment. COLUMBIA PICTURES e WARNER BROS., 1994. 142 min. Trecho: 59min07s-1h00min27s.

${ }^{68}$ CARDOSO, Carlos Raymundo. Entrevista concedida a Luisa de Araujo Tavares. 6 set. 2017.
} 
Dessa maneira, é possível constatar a interseccionalidade de vetores diametralmente opostos que se cruzam durante essa aplicação da privação da liberdade, tornando o viés terapêutico-reformador da sanção penal em uma verdadeira falácia. Certo é, e será demonstrado no decorrer deste estudo com referência a diversos pensadores sobre o tema, que o cárcere ilustra - de modo vívido - a hipocrisia humana.

\title{
2.3. O PROCESSO DE PRISONIZAÇÃO DA MASSA CARCERÁRIA A PARTIR DO EXPERIMENTO PRISIONAL DE STANFORD
}

\begin{abstract}
Quando uma pessoa ou grupo de ingresso penetra e se funde com outro grupo, dizse que ocorreu uma assimilação (...). De qualquer forma, devemos entender por assimilação o processo lento, gradual, mais ou menos inconsciente pelo qual a pessoa adquire o bastante da cultura de uma unidade, na qual foi colocada, a ponto de se tornar característico dela (...). O termo prisonização indica a adoção, em maior ou menor grau, do modo de pensar, dos costumes, dos hábitos - da cultura geral da penitenciária; corresponde à assimilação dos padrões vigorantes (...). Todo homem que é confinado ao cárcere sujeita-se à prisonização, em alguma extensão. ${ }^{69}$ - Grifo Nosso.
\end{abstract}

Como já aludido anteriormente, os padrões sociais do ambiente carcerário em muito diferem dos protótipos da comunidade que reside para além dos muros da prisão. O trecho supracitado corresponde a um indicativo inicial sobre o efeito das prisões no comportamento humano, que se enceta desde a chegada do apenado à penitenciária - momento em que se vê despido de suas individualidades, ou seja, perde tudo aquilo que faz dele o que ele é: roupas, nome, cabelo e, principalmente, privacidade. Trocando em miúdos, "transforma-se, de um golpe, numa figura anônima de um grupo subordinado"70.

Para além de questões jurídicas, já debatidas em ocasiões prévias neste trabalho de conclusão de curso, a análise que se trava quanto ao desajustamento sofrido pelo indivíduo que ingressa no cárcere possui raízes

\footnotetext{
${ }^{69}$ THOMPSON, Augusto. A questão penitenciária. 2.ed. Rio de Janeiro: Editora Forense, 1980. Parte I - Irrecuperação Penitenciária, Capítulo III, O Sistema Social da Prisão, IDEIAS GERAIS, p. 23.

${ }^{70}$ Ibid., p. 24.
} 
psicológicas. Citando, mais uma vez, o pesquisador pioneiro no tema, Augusto Thompson:

Provavelmente, de tal sorte sua personalidade desorganiza-se durante o processo de adaptação - na aceitação de um papel inferior; acumulação de fatos concernentes à organização da prisão; o desenvolvimento de novos hábitos, no comer, vestir, trabalhar, dormir; a adoção do linguajar local; o reconhecimento de que nada é devido ao meio ambiente, quanto à satisfação de necessidades; eventual desejo de arranjar uma "boa ocupação" - que se lhe torna difícil um ajustamento feliz à sociedade livre, quando a ela torna. $O$ preso novo desliza para dentro dos padrões existentes. Inexperiente da prisão ao nela adentrar, traumatizado, deslocado, indefeso, transforma-se na vítima de todo mundo: os guardas mantêmno sob asfixiante vigilância; os internos procuram explorá-lo de variadas maneiras; o terror das penalidades empurra-o a respeitar as infindáveis normas regulamentares; o pavor das agressões leva-o a se submeter às ameaças que repontam de todos os lados. Dentro de algum tempo, compreende que ou se adapta à sociedade na qual foi lançado, assumindo um dos papéis sociais disponíveis, ou sofrerá padecimentos insuportáveis. Prisonar-se será, normalmente, a solução: acostuma-se a comer apressadamente e a obter alimento através dos truques usados pelos que lhe estão próximos; aprende a jogar ou aprende novas maneiras de fazêlo; adquire comportamento sexual anormal; desconfia de todos; olha com rancor os guardas e, até, os companheiros. ${ }^{71}-$ Grifo Nosso.

Resta claro que o sistema prisional corresponde a uma peculiaridade que obriga os componentes da massa carcerária a adotarem outros/novos padrões de comportamento. Desenvolvem, por exemplo, uma dupla função sexual, pois “continuam, para o mundo externo, a serem tidos como homens, guardando absoluta discrição de suas práticas homossexuais intramuros"72.

Talvez o mais penoso de todos os sofrimentos da prisão esteja conectado com a proibição de relações heterossexuais. Não apenas pelo fato em si, mas, também, em face das inúmeras e variadas consequências que daí decorrem: à impossibilidade de sustentar a família, de obter recursos às suas custas, de tomar decisões, de ser responsável por suas coisas, de escolher a própria roupa, vem juntar-se o impedimento de possuir uma mulher - tudo gerando, no preso, o sentimento de castração simbólica. Sua masculinidade está posta em jogo e, com ela, obviamente, seu autoconceito. Apelando para a prática do homossexualismo, na forma ativa, torna-se viável minorar a angústia provocada por essa dúvida. ${ }^{73}$

Muito embora Thompson seja a referência bibliográfica principal deste tema, certo é que diversos estudiosos já se dedicaram ao assunto, como foi o caso do psicólogo Philip Zimbardo, ao realizar o Experimento de

\footnotetext{
${ }^{71}$ THOMPSON, Augusto. A questão penitenciária. 2.ed. Rio de Janeiro: Editora Forense, 1980. Parte I - Irrecuperação Penitenciária, Capítulo III, O Sistema Social da Prisão, IDEIAS GERAIS, p. 24-25.

${ }^{72}$ THOMPSON, Augusto. A questão penitenciária. 2.ed. Rio de Janeiro: Editora Forense, 1980. Parte I - Irrecuperação Penitenciária, Capítulo III, O Sistema Social da Prisão, OS PRESOS, p. 68.

${ }^{73}$ Ibid., p. 67-68.
} 
Aprisionamento de Stanford, no início da década de 1970, nos Estados Unidos: simulou-se, no porão da Universidade de Stanford, um ambiente de prisão, onde foram inseridos estudantes voluntários, divididos em dois grupos - os detentos e os guardas -, para examinar a origem do comportamento abusivo no sistema prisional. Uma experiência psicológica prevista para durar 2 (duas) semanas, sobreviveu apenas por 6 (seis) dias, pois se perdeu o controle dos desdobramentos da referida simulação, uma vez que, rapidamente, os participantes passaram de graduandos de classe média a sádicos embriagados pelo poder (os guardas) e vítimas submissas (os detentos).

Os prisioneiros, logo que ingressavam, eram compelidos a ficarem nus para se submeterem a uma "desintoxicação"; passavam a ser identificados pelo número que portavam em seus uniformes - correspondiam a um vestido cinza maltrapilho somente, não havendo o uso de roupas íntimas; carregavam correntes nos tornozelos e vestiam uma meia-calça na cabeça -; eram obrigados a manter o silêncio tanto nas horas de descanso como também durante as refeições. Ademais, somente lhes era permitido comer nos horários determinados, deveriam participar de todas as atividades do presídio e apenas poderiam se referir à guarda por "Sr. Guarda Prisional”. A violação de tais regras justificava punições como a ida para a solitária - um local escuro e estreito, onde eram privados de luz e comida.

Em questão de horas, alguns "presos" ao escreverem cartas para seus familiares já não mais assinavam pelo nome de batismo, mas sim pelo seu número. Em pouquíssimo tempo, os “detentos” passaram a se sujeitar a tratamentos humilhantes por parte dos "custodiadores", sem muito questionamento, como, por exemplo, (1) arrumar a cama diversas vezes até passar pelo crivo da guarda ou (2) acordar, no meio da madrugada, para realizar contagens, e quem se equivocasse tinha que pagar pelo erro com flexões.

Aqueles que não aceitaram, de forma pacífica, os dogmas da "prisão", promoveram motins e tentativas de fuga, sendo duramente castigados: 
tiveram seus vestidos rasgados e seus colchões foram levados de modo que foram obrigados a dormir no concreto sem roupa alguma; além disso, ficaram proibidos de usar o banheiro, restando-lhes apenas um balde para as necessidades básicas. Com o passar das horas, alguns jovens detentos, diante da escassez de comida, do sono e da luz do dia, começaram a desencadear distúrbios emocionais e pediram para serem liberados. No entanto, para os remanescentes, as punições foram tornando-se cada vez mais severas: eram forçados pela guarda a se despirem para que fossem "comidos" pelos colegas de cela, o que denotava total perda de intimidade.

Sobre tal aniquilamento, Thompson descreve em seu livro o cotidiano de um interno na penitenciária - que muito se assemelha, inclusive, ao retratado na "Prisão de Stanford":

Todos os dias, ao deixar o alojamento, pela manhã, o preso é revistado; ao voltar, à tarde, a operação se repete. Isso, contudo, não se antolha bastante. Durante a noite, com alguma frequência, pode ser acordado pelo barulho de chaves, a abrir o cadeado do cômodo. Entram guardas. Mandam que permaneça encostado à parede, junto da porta. Seus pertences, suas roupas, sua cama, tudo é revirado. São as "incertas", revistas realizadas de surpresa, numa galeria escolhida aleatoriamente. Haja ou não suspeitas ao seu respeito, a operação o inclui, pois a burocracia fiscalizadora não perde tempo com avaliações subjetivas. Se caminha no pátio, da "faxina" para o sanitário, pode ter os passos interrompidos por uma voz seca: "Você aí, espere!", um vigilante resolveu submetê-lo a uma revista extra. Levanta os braços, abre as pernas, deixa-se apalpar, mãos estranhas invadem-lhe os bolsos, dali retirando papéis, maço de cigarros, fósforos, cédulas de dinheiro e o que mais houver; às vezes o maço é rasgado por inteiro, um cigarro é desmanchado, bilhetes ou cartas, caso haja, são lidos cuidadosamente. Minutos depois, indo do sanitário para o refeitório, pode ser novamente escolhido, por outro guarda para outra revista, e a operação se repete, de forma idêntica. Pouco importa não registre sua história prisional uma única infração: a vistoria será feita com a mesma suspicácia, pois sua condição de preso gera fortes razões para ser julgado um indivíduo absolutamente carecedor de confiança. "Preso é preso" - dito corrente entre os funcionários - iguala todos os internos como objetos depravados e perigosos. ${ }^{74}$ - Grifo Nosso.

\section{No mesmo sentido, versa Simone Buffard:}

A revista corporal é vista, sempre, como uma violação, qualquer que seja a delicadeza - às vezes real - daquele que a opera e cuja situação é tão penosa quanto a do preso. Entre múltiplas queixas expressas pelos detentos, ela aparece raramente ou, então, sob uma forma atenuada, ou escamoteada, sem esses pormenores crus, geralmente abundantes, por força de seus propósitos. Aqueles dentre nós que,

\footnotetext{
${ }^{74}$ THOMPSON, Augusto. A questão penitenciária. 2.ed. Rio de Janeiro: Editora Forense, 1980. Parte I - Irrecuperação Penitenciária, Capítulo III, O Sistema Social da Prisão, OS PRESOS, p. 6061.
} 
acidentalmente, foram vítimas da experiência, por parte de zelosos agentes alfandegários, podem fazer ideia dessas apalpadelas, mesmo que elas não tenham chegado à exploração da cavidade anal; tanto quanto os fiscais da aduana, os guardas não experimentam prazer com essa maçada, e se os detentos os suspeitam de gozá-las, é porque estes se sentem, então, como objetos submetidos ao desejo de outrem. A revista não é nem pode ser considerada como uma simples operação de controle: ela agride, ao mesmo tempo, o corpo real, o corpo imaginário e o corpo simbólico. O homem revistado é um homem possuído. ${ }^{75}$ - Grifo Nosso.

Nota-se, portanto, um fenômeno de desindividualização que, além de ir em sentido contrário ao empoderamento necessário para "atingir o objetivo de transformar criminosos em não-criminosos" $" 76$, ainda gera traumas que marcam o indivíduo, afetando a sua psiquê. Os relatos dos jovens "detentos" que se voluntariaram para esse laboratório de Stanford carregam esse peso:

"Vi logo que algo estava errado. Aliás, fui o único. Só eles é que não percebiam. Dão a eles um uniforme, com os óculos e o porrete, e deixam de ser quem seriam com roupas normais. Eu era só um número num vestido. Não era um detento numa experiência, mas sim prisioneiro deles" (Prisioneiro $\left.n^{\circ} 416\right)^{77}-$ Grifo Nosso.

"Senti que estava perdendo a minha identidade. Que a pessoa a quem chamo Tom estava desaparecendo. Para mim era uma prisão. Continua a ser, ainda hoje. Não a vejo como uma experiência ou simulação. Era uma prisão gerida por psicólogos e não pelo Estado" (Prisioneiro n $\left.{ }^{\mathbf{0}} 2093\right)^{78}$ - Grifo Nosso.

Diante do exposto, resta claro concluir, nas palavras de Augusto Thompson, que

As regulações minuciosas, estendendo-se a toda área da vida individual, a vigilância constante, a concentração de poder nas mãos de uns poucos, $o$ abismo entre os que mandam e os que obedecem, a impossibilidade de simbiose de posições entre os membros das duas classes - tudo concorre para identificar o regime prisional como um regime totalitário.$^{79}$ - Grifo Nosso.

\footnotetext{
75 BUFFARD, Simone. Le Froid Pénitenciaire. Paris: Ed. Seuil, 1973, p. 47-48.

76 THOMPSON, Augusto. A questão penitenciária. 2.ed. Rio de Janeiro: Editora Forense, 1980. Parte I - Irrecuperação Penitenciária, Capítulo II, Fins Contraditórios Atribuídos à Pena de Prisão, INCONSISTÊNCIA DE ATRIBUIR O FRACASSO DA PRISÃO REGENERADORA À DEFICIÊNCIA DOS RECURSOS MATERIAIS, p. 16.

${ }^{77}$ EXPERIMENTO de Aprisionamento de Stanford, O. Direção: Kyle Patrick Alvarez. Produção: Brent Emery, Lizzie Friedman, Lauren Bratman, Christopher McQuarrie, Karen Lauder e Greg Little. Intérpretes: Billy Crudup, Ezra Miller, Michael Angarano e outros. Roteiro: Tim Talbott, Christopher McQuarrie e P.W. Hopsidor. Abandon Pictures. UNIVERSAL PICTURES. 2015. 122 min. Trecho: 1h54min21s-1h54min39s.

${ }^{78}$ Ibid., Trecho: 1 h54min41s-1h55min10s.

79 THOMPSON, Augusto. Op. cit., Capítulo III, O Sistema Social da Prisão, IDEIAS GERAIS, p. 22.
} 
Com isso, deflagra-se a profunda hipocrisia das sociedades democráticas quanto à aplicação da prisão-pena, uma vez que permitem, em seu interior, o engendramento de um sistema movido por ditames ditatoriais. Os muros altos do cárcere servem como instrumento para legitimar uma cegueira coletiva que, por sua vez, sustenta um instituto originalmente corrupto e falido.

O muro da prisão, física e simbolicamente, separa duas populações distintas: a sociedade livre e a comunidade daqueles que foram, por ela, rejeitados. A altura e espessura da barreira, a presença, no cimo, de soldados armados de metralhadoras, o portão pesado com pequenas viseiras, cuja abertura exige uma operação complicada por várias medidas de segurança, estão a demonstrar, inequivocamente, que os rejeitadores desejam muito pouco contato com os rejeitados. $\mathrm{O}$ uniforme destes, o estado de subordinação permanente, as trancas, os conferes, as revistas, lembram-nos, a todo instante, serem portadores de um estigma, tão aparente e difícil de arrancar quanto o produzido pelo ferrete na rês. Tudo é organizado de sorte a lhes propiciar a nítida e clara sensação de pertencerem à mais baixa camada social, em termos de status. A sociedade timbra em mostrar que os define, não como sua parte subordinada, mas como uma classe moralmente inferior de pessoas, cuja manutenção representa um custo, objetos a serem manipulados, sem direito a emitir opinião acerca do modo por que isso será feito. ${ }^{80}$ - Grifo Nosso.

A respeito ainda dessas subcondições às quais são jugulados os presos na vida intramuros, em entrevista coletiva concedida por Celia Passos, Maria do Céu Battaglia e Samantha Pelajo no dia 2 de outubro de 2017, Celia menciona uma provocação que tem feito em palestras, traçando um paralelo com a época do Holocausto na Segunda Guerra Mundial:

Para e pensa: você faz alguma coisa porque está institucionalizado. Hoje, a gente olha o que aconteceu no Holocausto e nos questionamos como o ser humano foi capaz. Tenho para mim que se entendermos o que acontece nesses presídios, talvez um dia essas pessoas, que estão nesse contexto e decidem por encarcerar, sejam olhadas pela sociedade daqui a uns anos com esse mesmo espanto como olhamos o Holocausto - essa etapa da história da humanidade - e se questionem com perplexidade "mas como fizeram isso com as pessoas?" ou "por que faziam isso?". Qual será a justificativa? "Estava cumprindo ordens", "era o que a lei dizia", "era o meu dever", "estava cumprindo a minha obrigação". Mas você não questionava esse dever? Mas você não questionava essa obrigação? Tá bonito, né? Olha para trás, se envergonha e se entristece por quem você poderia ter sido e não foi. ${ }^{81}$ - Grifo Nosso.

\footnotetext{
${ }^{80}$ THOMPSON, Augusto. A questão penitenciária. 2.ed. Rio de Janeiro: Editora Forense, 1980. Parte I - Irrecuperação Penitenciária, Capítulo III, O Sistema Social da Prisão, OS PRESOS, p. 5556.

${ }^{81}$ PASSOS, Celia; BATTAGLIA, Maria do Céu; PELAJO, Samantha. Entrevista concedida a Luisa de Araujo Tavares. 2 out. 2017.
} 
Resta claro que, na conjuntura atual, o tratamento cruel ao encarcerado é moralmente permitido por ser este considerado pertencente a uma classe inferior à do ser humano. Segue a mesma visão coisificada atribuída aos negros na escravatura e, também, com relação aos judeus na Alemanha nazifascista: contextos em que um setor da sociedade é desumanizado. Maria do Céu Battaglia, psicoterapeuta, explica essa estratégia de objetificação para justificar as práticas tirânicas do cárcere, tão pedido e aclamado pela sociedade atual:

É tão absurda a sujeição à violência do sistema carcerário, atualmente, que nós precisamos nos desconectar do outro - como ser humano - para suportar. Se você coisifica o seu semelhante, tornando-o em uma coisa ruim, da qual repudia, uma peste, consequentemente se permite agir com ele da forma que bem deseja, exercendo atos, inclusive, que não executaria com uma outra pessoa por impedimento moral. O processo de afastamento ocorre pela transformação do preso, do escravo, do judeu em um objeto que causa repulsa, pois, a partir daí, está liberado psiquicamente a fazer qualquer coisa, visto que com um objeto eu procedo como bem entender. ${ }^{82}$ - Grifo Nosso.

A prisonização - essa institucionalização da lógica carcerária - afeta o psicológico não somente da massa carcerária, como também de "todos os partícipes" $" 83$ do sistema, abalando o modo de se comportar, de se posicionar e de decidir. A interferência é real e age, muitas vezes, de modo imperativo e imperceptível, sendo uma assimilação difícil de ser evitada. Tal abrangência será objeto de estudo e exame na seção seguinte.

\subsection{A REAL EXTENSÃO dOS VALORES E PADRÕES VIGORANTES NA PENITENCIÁRIA}

Importante perceber que, no experimento em Stanford supracitado, não apenas os jovens que foram detentos, como também aqueles que participaram da guarda, tiveram seus comportamentos afetados pelo ambiente prisional em que se encontraram inseridos por 6 (seis) dias:

\footnotetext{
${ }^{82}$ PASSOS, Celia; BATTAGLIA, Maria do Céu; PELAJO, Samantha. Entrevista concedida a Luisa de Araujo Tavares. 2 out. 2017.

${ }^{83}$ THOMPSON, Augusto. A questão penitenciária. 2.ed. Rio de Janeiro: Editora Forense, 1980. Parte I - Irrecuperação Penitenciária, Capítulo III, O Sistema Social da Prisão, IDEIAS GERAIS, p. 26.
} 
"Eu também quis fazer experiências. Queria ver que tipos de abusos verbais as pessoas aguentam até começarem a reclamar e a reagir. E me surpreendeu que ninguém tenha dito nada para me fazer parar. Ninguém disse: 'você não pode me dizer isso, é doentio'. Ninguém questionou a minha autoridade. E fiquei muito chocado. Comecei a tratar tão mal as pessoas, perdi todo o respeito e, mesmo assim, ninguém disse nada." (Guarda John Wayne) ${ }^{84}-$ Grifo Nosso.

"É fácil afirmar que não teriam agido daquela forma. Mas não dá para saber. É verdade, não dá. Agora sei do que sou capaz, e isso fere. Não sei dizê-lo de outra forma, mas fere-me sabê-lo." (Guarda Simulado) ${ }^{85}$ - Grifo Nosso.

Assim, é razoável aferir, pelas falas supracitadas, que "os carcereiros também sofrem os efeitos da prisonização" ${ }^{86}$, ou seja, "abandonam os padrões que observam na vida extramuros, para - pelo menos enquanto estão intramuros - adotar os valores ali vigorantes" $"$ ". A adoção de um comportamento desviante, todavia, não se restringe a essas duas classes do sistema prisional.

Observa-se ainda, no experimento, que os psicólogos - integrantes da direção do "presídio" - chegaram a um nível de envolvimento tamanho, que se tornaram parte da experiência: eram coniventes com algumas demonstrações de força física contra os presos - proibida em um primeiro momento -, aderiram à "segurança" quando ouviram rumores sobre um plano de fuga, tratavam os internos com desrespeito e indiferença nas reuniões para concessão de livramento condicional. Em vista disso, constata-se que "todos os partícipes da relação penitenciária sofrem os efeitos da prisonização". 88 No que tange à direção da penitenciária, Augusto Thompson atenta para o fato de que:

O diretor situa-se, entre custodiadores e custodiados, como o fiel da balança: os primeiros precisam dele para fazer valer a autoridade de que devem estar investidos; os segundos identificam-no como o único poder capaz, e a que têm

\footnotetext{
${ }^{84}$ EXPERIMENTO de Aprisionamento de Stanford, O. Direção: Kyle Patrick Alvarez. Produção: Brent Emery, Lizzie Friedman, Lauren Bratman, Christopher McQuarrie, Karen Lauder e Greg Little. Intérpretes: Billy Crudup, Ezra Miller, Michael Angarano e outros. Roteiro: Tim Talbott, Christopher McQuarrie e P.W. Hopsidor. Abandon Pictures. UNIVERSAL PICTURES. 2015. 122 min. Trecho: 1h57min14s-1h57min50s.

${ }^{85}$ Ibid., Trecho: $1 \mathrm{~h} 53 \min 55 \mathrm{~s}-1 \mathrm{~h} 54 \mathrm{~min} 13 \mathrm{~s}$.

${ }^{86}$ THOMPSON, Augusto. A questão penitenciária. 2.ed. Rio de Janeiro: Editora Forense, 1980. Parte I - Irrecuperação Penitenciária, Capítulo III, O Sistema Social da Prisão, IDEIAS GERAIS, p. 26.

${ }^{87}$ Ibid., p. 27.

${ }^{88}$ Ibid., p. 28.
} 
acesso, de impor balizas a tal autoridade. Naturalmente, dentro de dados limites, haverá uma certa variação de comportamento, no sentido de tender mais para um lado do que para o outro. Esse elemento vai definir o caráter da administração: severa, se pende para a guarda; bondosa, se pende para os presos. O diretor ideal, como diz o velho ditado da cadeia, repetido por presos e guardas, é aquele que não é nem bom nem mau, mas justo, se atendo aos fatos numa perspectiva objetiva (...). Assim, constatado um fato concreto, em desacordo com os regulamentos, o seu autor deve ser apenado, desprezadas as considerações particulares e pessoais a seu respeito. ${ }^{89}$ - Grifo Nosso.

Isso significa que comandar uma penitenciária demanda certa habilidade do ocupante do cargo de diretor para que "as sentenças sejam reconhecidas como justas, impessoais e certas" árduo enfrentar, na prática, problemas dessa natureza"91, Thompson narra um episódio de sua vivência:

Havia um guarda, num dos estabelecimentos da SUSIPE, especialista em instigações: se um preso se rebela ou insulta um guarda, espera-se que seja enviado para a cela surda, embora tudo indique ter agido de tal forma porque a vítima, a título de cumprir sua tarefa fiscalizadora, exasperou o infrator até o desespero, através de revistas amiudadas, de tratamento rude e provocações de toda ordem, disfarçadas em zelo pelo dever. Seu diretor não tinha alternativa, sancionava-lhe as partes, mas procurava dar-lhe a entender o quanto desapreciava seu comportamento. Inúteis as medidas tomadas, veio ao meu encontro e pediu que transferisse o funcionário para a Ilha Grande - punição informal de que nos socorríamos em casos de gravidade. Atendi à solicitação. Pouco depois, fui procurado pelo guarda em causa. Queria que a ordem de transferência fosse revogada, argumentando que, através dela, estava sendo punido exatamente pelo fato de ser cioso no cumprimento do dever. E ameaçava assumir uma atitude de inércia, daí para frente, caso fosse mantido o castigo: "Posso ter certeza de que o preso tá carregando maconha, que não vou revistá-lo; posso ter informação segura de outro que tá com arma escondida no cubículo que não vou lá ver; pode passar nas minhas barbas um interno em local proibido que não vou verificar se tem autorização; é... vou deixar a cadeia correr frouxa". Naturalmente, sustentei que a transferência decorria da necessidade do serviço e adverti-o de que, se não cumprisse suas obrigações, sofreria as sanções estatutárias previstas. Com o que mentia duas vezes: $1^{\mathrm{a}}$ porque o caráter punitivo da transferência era manifesto; $2^{\mathrm{a}}$ porque sabia ser inviável comprovar, devidamente, a falta omissiva que o servidor prometia cometer. ${ }^{92}$

Dessa forma, a direção prisoniza-se para conseguir atender tanto a demanda externa - preocupada com possíveis motins e fugas dos detentos -, como também a própria dinâmica da célula carcerária, mantendo "um

\footnotetext{
${ }^{89}$ THOMPSON, Augusto. A questão penitenciária. 2.ed. Rio de Janeiro: Editora Forense, 1980. Parte I - Irrecuperação Penitenciária, Capítulo III, O Sistema Social da Prisão, A DIREÇÃO, p. 35.

${ }^{90}$ Ibid., p. 36.

${ }^{91}$ Ibid., p. 37.

${ }^{92}$ Ibid., p. 38.
} 
equilíbrio entre guardas e internos, através de uma justiça impessoal, padronizada e objetiva" ${ }^{93}$, o que garante a ordem interna da cadeia. Com relação à manifestação dessa prisonização, Carlos Raymundo Cardoso, exdiretor da penitenciária Lemos Brito, supramencionado, conta a seguinte reflexão, que travou consigo mesmo, quando já operava como promotor da Vara de Execuções Penais:

Dentre as funções do promotor da Vara de Execuções Penais está a de fiscalizar os presídios. Um belo dia resolvi fiscalizar o Lemos Brito de onde tinha saído meses antes. Fui à Ilha Grande como promotor da VEP. Voltei à cadeia, fui recebido pelo meu sucessor - um coronel da polícia militar, o coronel Gerino - que mostrou a cadeia que eu já conhecia. Em um certo momento, quis ir nas celas dos castigos no último pavilhão do fundo: quando abriram as celas para ver se tinha algum preso lá dentro, eu olhei e me perguntei como tive coragem de colocar alguém ali dentro sem nenhum peso na consciência. Quando o Mariel Mariscot fugiu e depois foi recapturado, o Thompson me pediu que o recolhesse no Lemos Brito, por ser o lugar que ele considerava mais seguro para manter o Mariel até definir a situação dele: eu coloquei o Mariel nu dentro da cela. Como eu tive coragem de fazer isso? Eu era muito novo, tinha 26 anos, mas é a prisonização. Você se embrutece. Eu saí mal dali. Quem vai trabalhar na cadeia se prisoniza depois de um certo tempo porque, se você não se prisonizar, você não aguenta o trabalho: será sempre um inadaptado. ${ }^{94}$ - Grifo Nosso.

Seguindo essa mesma diretriz, Thompson - diretor-geral do departamento penitenciário, no mesmo período em que Carlos Raymundo era diretor de presídio - justifica que:

Essa adaptação é a única explicação viável para tornar compreensível a atitude de um diretor que pune um interno, por ter sido encontrado na posse de uma dose de cachaça, a dez, vinte ou trinta dias de "surda". Tal castigo é cumprido numa cela nua, o condenado dormindo no cimento puro, trancado dia e noite, em completo isolamento, ali recebendo as refeições que, naturalmente, chegam frias. Como um bacharel de Direito, um membro do Ministério Público, um oficial das Forças Armadas, pode ditar comandos de tal natureza, sem traumatizar a própria consciência? A única justificação é a de que, enquanto está intramuros, substitui a tábua de valores adotada na vida livre por outra, que lhe é fornecida (ou impingida) pelo sistema social da penitenciária, já estereotipada e amparada numa série de racionalizações. Passa a viver duas vidas, e essa duplicidade está simbolizada numa frase que se habituará a repetir: "Cadeia é cadeia!". Como superintendente, não aplicava penalidades. Contudo, na qualidade de instância recursal, confirmei, muitas vezes, castigos dessa natureza impostos por meus diretores. O que, hoje, só consigo compreender pela admissão de estar, na época, profundamente prisonizado ${ }^{95}$ - Grifo Nosso.

\footnotetext{
93 THOMPSON, Augusto. A questão penitenciária. 2.ed. Rio de Janeiro: Editora Forense, 1980. Parte I - Irrecuperação Penitenciária, Capítulo III, O Sistema Social da Prisão, A DIREÇÃO, p. 38.

${ }^{94}$ CARDOSO, Carlos Raymundo. Entrevista concedida a Luisa de Araujo Tavares. 6 set. 2017.

95 THOMPSON, Augusto. Op. cit., IDEIAS GERAIS, p. 27-28.
} 
Portanto, como já afirmado em momento anterior, verifica-se que a cultura do cárcere transborda a massa carcerária e atinge todas as classes do "sistema social da prisão" 96, que correspondem, além dos presos, aos guardas, à direção e aos "especialistas terapeutas"97. Trazendo mais uma experiência de Carlos Raymundo Cardoso, na época em que atuou como juiz da Vara de Execuções Penais, a título de ilustração:

Quando juiz da Vara de Execuções Penais, uma psicóloga do DESIPE me procurou para pedir o livramento condicional de um preso. Com 2 (dois) minutos de conversa, eu não sabia mais se estava falando com uma psicóloga de fato ou com uma presa por causa do vocabulário. Ela incorporou de tal forma o linguajar da penitenciária que não fazia mais distinção, simplesmente se comunicava daquele jeito sempre. ${ }^{98}$

Os médicos, psiquiatras, psicólogos, educadores e assistentes sociais agem para a regeneração dos apenados: uma função da pena privativa de liberdade que, como já demonstrado em folhas pregressas neste estudo, é diametralmente oposta aos ideais de segurança e disciplina - dever que recai diretamente sobre a guarda prisional. Inicia-se, "em face da contradição de tais objetivos" $"$, um cabo de guerra entre "os custodiadores e os especialistas da terapia" 100 , muito bem descrito por Thompson:

Os psicólogos alegam que sem uma atmosfera permissiva ficam impossibilitados de obter resultados positivos no seu campo. Os guardas retrucam que, se o ritmo que imprimem à cadeia for quebrado pelo rompimento do esquema de estreita vigilância com os presos, a instituição se transformará num caos. Aqueles requerem tratamento especial para cada paciente sob seus cuidados, de acordo com a psicologia particular de cada um; estes respondem que, se a rotina prisional for perturbada, com a adoção de regimes diversos para cada indivíduo, a disciplina ficará irremediavelmente comprometida. Os assistentes sociais aconselham que sejam autorizados este ou aquele interno a receber visitas especiais; os agentes de segurança sustentam que, se o comportamento deles não for de molde a justificar a medida, não poderão gozá-la, pois o deferimento de privilégios a quem não os merece, regulamentarmente, pode fazer desandar a ordem da casa. Os professores exigem que os alunos compareçam em horários certos e, sobretudo, com assiduidade às aulas; os vigilantes declaram que, se razões de segurança e disciplina impedem o atendimento da exigência, ela deverá ser enjeitada, uma vez que estes motivos têm precedência sobre os dos mestres. O que mais irrita a

\footnotetext{
${ }^{96}$ THOMPSON, Augusto. A questão penitenciária. 2.ed. Rio de Janeiro: Editora Forense, 1980. Parte I - Irrecuperação Penitenciária, Capítulo III, O Sistema Social da Prisão, IDEIAS GERAIS, p. 19.

${ }^{97}$ Ibid., p. 22.

${ }^{98}$ CARDOSO, Carlos Raymundo. Entrevista concedida a Luisa de Araujo Tavares. 6 set. 2017.

${ }^{99}$ THOMPSON, Augusto. Op. cit., OS TERAPEUTAS, p. 52.

${ }^{100}$ Ibid., p. 53.
} 
guarda é a circunstância de que um trabalho ativo dos especialistas faz aumentar a circulação dos internos, dentro da cadeia, uma vez que terão de ir a mais lugares. Isso complica o problema da segurança. ${ }^{101}$ - Grifo Nosso.

Diante dessa rixa, pressionada pelos "controles informais do mundo livre" ${ }^{102}$, a direção despreza a recuperação advinda do tratamento terapêutico para "se dedicar precipuamente à tarefa de manter a cadeia segura $e$ disciplinada"103. Consequentemente, esses profissionais com expertise são tomados por um sentimento de frustração e, desestimulados pela própria dinâmica do sistema, "passam a executar suas funções burocraticamente"104; em outras palavras, prisonizam-se. Como bem formula Thomas Mathiesen:

Dentro dessa situação é que precisamos entender os pontos de vista e as reações dos membros da equipe de tratamento, em geral, e dos psiquiatras, em particular. Os últimos sentem, frequentemente, que, de fato, entram na instituição como peritos fracassados. Uma vez nela, certos arranjos organizacionais parecem-lhes restringir suas possibilidades de sucesso ainda mais. ${ }^{105}$ - Grifo Nosso.

Assim sendo, é possível inferir que a prisão, desde seu surgimento como sanção penal, foi feita para não ter êxito reformativo. Consubstanciase em uma comunidade independente, com valores e padrões de funcionamento próprios, formada por indivíduos que foram expulsos da sociedade livre. Desse modo, qualquer cidadão do mundo extramuros que entre em contato com o sistema prisional - ainda que temporariamente e por tempo determinado -, para conseguir adaptar-se à dinâmica intramuros, se vê obrigado a prisonar-se.

\footnotetext{
101 THOMPSON, Augusto. A questão penitenciária. 2.ed. Rio de Janeiro: Editora Forense, 1980. Parte I - Irrecuperação Penitenciária, Capítulo III, O Sistema Social da Prisão, OS TERAPEUTAS, p. 53-54.

${ }^{102}$ THOMPSON, Augusto. A questão penitenciária. 2.ed. Rio de Janeiro: Editora Forense, 1980. Parte I - Irrecuperação Penitenciária, Capítulo II, Fins Contraditórios Atribuídos à Pena de Prisão, METAS INFORMAIS - TESTILHA COM O ALVO REGENERAÇÃO, p. 9.

${ }^{103}$ THOMPSON, Augusto. Op. cit., p. 52.

${ }^{104}$ Ibid., p. 55.

${ }^{105}$ MATHIESEN, Thomas. The Defences of the Weak. Londres: Tavistock Publ., 1972, p. 64.
} 


\title{
CAPÍtULO 3. NOVOS RUMOS NA EXECUÇÃO PENAL BRASILEIRA
}

\subsection{INVERSÃO NA LÓGICA DO SISTEMA PROGRESSIVO- REGRESSIVO COMO FERRAMENTA DE TRANSIÇÃO PENSADA POR AUGUSTO THOMPSON}

\begin{abstract}
Se a penitenciária tem que atender às exigências de segurança e disciplina, deve ser encarada como uma instituição custodial e não como uma instituição reformativa. A ilusão de que a pena de prisão pode ser reformativa mostra-se altamente perniciosa, pois enquanto permanecemos gravitando em torno a essa falácia, abstemo-nos de examinar seriamente outras viáveis soluções para o problema penal. ${ }^{106}$ - Grifo Nosso.
\end{abstract}

O presente capítulo tem como objetivo examinar e propor "outras viáveis soluções para o problema penal" ${ }^{107}$ de modo que a aplicação de sanções carregue, em efetivo, uma finalidade reformativa. Após toda a análise exposta sobre a deformação que o cárcere provoca no aspecto existencial do ser humano, resta evidente que as instituições prisionais, cuja finalidade seja cumprimento de pena, devem ser extintas. Em outras palavras, o caráter sancionatório que a prisão adquiriu no decorrer histórico - abordado no primeiro capítulo - deve ser esvaziado. As prisões, na conjuntura atual, como bem o adverte Foucault, são fábricas que acabam por produzir delinquentes, condicionando os encarcerados à reincidência ao regressarem para a vida livre ${ }^{108}$ :

Se tal é a situação, a prisão, ao aparentemente "fracassar", não erra seu objetivo; ao contrário, ela o atinge na medida em que suscita no meio das outras uma forma particular de ilegalidade, que ela permite separar, pôr em plena luz e organizar como um meio relativamente fechado, mas penetrável. Ela contribui para estabelecer uma ilegalidade visível, marcada, irredutível a um certo nível e secretamente útil - rebelde e dócil ao mesmo tempo; ela desenha, isola e sublinha uma forma de ilegalidade que parece resumir simbolicamente todas as outras, mas que permite deixar na sombra as que se quer ou se deve tolerar. Essa forma é a

\footnotetext{
106 THOMPSON, Augusto. A questão penitenciária. 2. ed. Rio de Janeiro: Editora Forense, 1980. Parte I - Irrecuperação Penitenciária, Capítulo III, O Sistema Social da Prisão, CONCLUSÃO, p. 93. ${ }^{107}$ Ibid., 92.

${ }^{108}$ FOUCAULT, Michel. Vigiar e punir: nascimento da prisão. Tradução: Raquel Ramalhete. 42.ed. Petrópolis: Editora Vozes, 2014. Quarta Parte: Prisão, Capítulo II - Ilegalidade e delinquência, p. 258.
} 
delinquência propriamente dita. Não devemos ver nesta forma mais intensa e mais nociva de ilegalidade, aquela que o aparelho penal deve mesmo tentar reduzir pela prisão por causa do perigo que representa; ela é antes um efeito da penalidade (e da penalidade de detenção) que permite diferenciar, arrumar e controlar as ilegalidades. Sem dúvida a delinquência é uma das formas de ilegalidade; em todo caso, tem suas raízes nela; mas é uma ilegalidade que o "sistema carcerário", com todas as suas ramificações, investiu, recortou, penetrou, organizou, fechou num meio definido e ao qual deu um papel instrumental, em relação às outras ilegalidades. Em resumo, se a oposição jurídica ocorre entre legalidade e prática ilegal, a oposição estratégica ocorre entre as ilegalidades e a delinquência. $\mathrm{O}$ atestado de que a prisão fracassa em reduzir os crimes deve talvez ser substituído pela hipótese de que a prisão conseguiu muito bem produzir a delinquência, tipo especificado, forma política ou economicamente menos perigosa - talvez até utilizável - de ilegalidade; produzir os delinquentes, meio aparentemente marginalizado, mas centralmente controlado; produzir o delinquente como sujeito patologizado. O sucesso da prisão: na luta em torno da lei e das ilegalidades, especificar uma "delinquência". Vimos como o sistema carcerário substituiu o infrator pelo "delinquente". E afixou também sobre a prática jurídica todo um horizonte de conhecimento possível. Ora, esse processo de constituição da delinquência-objeto se une à operação política que dissocia as ilegalidades e delas isola a delinquência. A prisão é o elo desses dois mecanismos; permite-lhes reforçarem perpetuamente um ao outro, objetivar a delinquência por trás da infração, consolidar a delinquência no movimento das ilegalidades. O sucesso é tal que, depois de um século e meio de "fracasso", a prisão continua a existir, produzindo os mesmos efeitos e que se têm os maiores escrúpulos em derrubá-la. ${ }^{109}$ - Grifo Nosso.

Obviamente, é ingênuo acreditar que esse desaparecimento ocorrerá de forma abrupta. Trata-se de um processo gradativo. Grandes mudanças começam a partir de pequenos passos. Assim sendo, necessária se faz, nesse primeiro momento da caminhada de transição, uma inversão na lógica do sistema progressivo-regressivo de regimes na execução da pena prisional pensada e formulada por Augusto Thompson em sua obra A Questão Penitenciária - para desafogar a cadeia.

Sendo inevitável, por agora, aplicar uma pena com conteúdo punitivo e intimidativo a quem cometer um delito, procuremos fazê-lo de forma a que ela seja o menos possível conduzente a transformar o criminoso em mais criminoso. Se não podemos ainda agir para melhorar o paciente, pelo menos não trabalhemos para piorá-lo. ${ }^{110}$ - Grifo Nosso.

\footnotetext{
${ }^{109}$ FOUCAULT, Michel. Vigiar e punir: nascimento da prisão. Tradução: Raquel Ramalhete. 42.ed. Petrópolis: Editora Vozes, 2014. Quarta Parte: Prisão, Capítulo II - Ilegalidade e delinquência, p. 262-263.

110 THOMPSON, Augusto. A questão penitenciária. 2.ed. Rio de Janeiro: Editora Forense, 1980. Parte II - Sugestões para uma Reforma Penal, Capítulo IV, Regime de Execução da Pena Prisional, CONCLUSÃO, p. 152.
} 
Uma situação crítica da atualidade é a superlotação dos presídios. Segundo informações publicadas no portal do CNJ (Conselho Nacional de Justiça), no dia 23 de fevereiro de 2017, a população carcerária brasileira correspondia a 654.372 presos, dos quais 221.054 eram presos provisórios. Isso significa que o Brasil ultrapassa o contingente carcerário da Rússia (644.237 presos) e se torna o país com a $3^{\text {a }}$ (terceira) maior coletividade de detentos no mundo, estando atrás somente dos Estados Unidos (2.217.000 presos) e da China (1.657.812 presos) ${ }^{111}$. Embora muitos defendam a construção de mais presídios, a análise feita até então, nesta monografia, comprova não ser uma hipótese de solução viável, visto que de nada adianta "aumentar a dose de um remédio que não leva à cura""112.

Ademais, tendo como foco o Brasil, há que se ter em mente que a realidade prisional muito se distancia do previsto na legislação brasileira. Ricardo Lewandowski, ministro do Supremo Tribunal Federal, em uma entrevista concedida ao programa televisivo Fantástico para integrar uma reportagem que buscava respostas para a seguinte pergunta: "A progressão de pena funciona mal por que é falha ou por que o Estado não atende às exigências da lei?", afirmou que:

A legislação prevê que as penas devem ser cumpridas em estabelecimentos distintos, segundo a natureza do delito, o sexo e a idade do criminoso. Isso não acontece. Todos são amontoados no mesmo estabelecimento prisional. Além disso, desde 1984, nós não temos essas colônias penais agrícolas - para o cumprimento do semiaberto - e também não temos casas do albergado. Portanto, o sistema não funciona. ${ }^{113}$ - Grifo Nosso.

\footnotetext{
${ }^{111}$ PORTAL DO CONSELHO NACIONAL DE JUSTIÇA - Levantamento dos Presos Provisórios do País e Plano de Ação dos Tribunais. Disponível em: 〈http://www.cnj.jus.br/noticias/cnj/84371levantamento-dos-presos-provisorios-do-pais-e-plano-de-acao-dos-tribunais $>$. Acesso em: 13 set. 2017.

112 THOMPSON, Augusto. A questão penitenciária. 2.ed. Rio de Janeiro: Editora Forense, 1980. Parte II - Sugestões para uma Reforma Penal, Capítulo IV, Regime de Execução da Pena Prisional, IRRACIONALIDADE DO SISTEMA PROGRESSIVO, p. 144.

${ }^{113}$ LEWANDOWSKI, Ricardo. In: PROGRESSÃO de pena funciona mal por que é falha ou por que o estado não atende às exigências da lei?. Direção: Marcelo Canellas. Produção: Vera Souto. Edição: Joelson Maia. Técnicos: Paulo Martins e Jorge Sant'anna. Arte: Alexandre Beltran. Imagem: Lúcio Alves. FANTÁSTICO. REDE GLOBO. 6 dez. 2015. 15min47s. Disponível em: <http://g1.globo.com/fantastico/noticia/2015/12/fantastico-ouve-especialistas-e-vitimas-sobreprogressao-de-pena.html>. Acesso em: 13 set. 2017. Trecho: 6min06s-6min30s.
} 
Na mesma matéria jornalística supracitada, é realizada uma visita guiada pelo Juiz da Vara de Execuções Penais de Porto Alegre, Sidinei Brzuska, ao Presídio Central de Porto Alegre - a maior cadeia do Brasil, que reúne cerca de 4.300 presos -, na qual se deflagra a precariedade de recursos da penitenciária: galerias com capacidade máxima para 60 pessoas, aproximadamente, alocam por volta de 400 detentos. Sidinei Brzuska entende ser essa carência de condições mínimas para suprir as necessidades básicas do ser humano o que acarreta o ingresso de presos em facções criminosas:

O Estado não dá uma barra de sabão para o sujeito se lavar, não dá um creme dental para ele fazer sua higiene, não dá uma muda de roupa, não dá uma colher para ele comer. A captação das facções se dá nessas coisas elementares em que há uma omissão estatal e não pela força. ${ }^{114}$ - Grifo Nosso.

O juiz ainda compartilha situações cotidianas com as quais tem que lidar ao exercer seu ofício, operando em um sistema totalmente desprovido e arruinado:

O maior constrangimento da minha vida como juiz de direito eu passei aqui dentro do presídio. O preso me perguntou: "Doutor, essa assinatura aqui é sua? Foi o senhor que assinou aqui?"; respondi afirmativamente e, então, ele me indagou: “A sua assinatura vale? Porque se a sua assinatura vale, o que é que eu estou fazendo aqui? O senhor me mandou para o semiaberto e eu continuo no fechado. E se não vale a sua assinatura, o que é que o senhor está fazendo aqui?". E eu decidi que a minha assinatura vale: eu determino a remoção para o semiaberto e, se o Estado não retira por falta de vaga, eu solto o preso. ${ }^{115}$ - Grifo Nosso.

Esta crua realidade comprova a "irracionalidade do sistema progressivo" 116 e, por conseguinte, a necessidade da "adoção de um sistema regressivo" 117 . A Lei de Execução Penal Brasileira (Lei 7.210/84) dispõe

\footnotetext{
${ }^{114}$ BRZUSKA, Sidinei. In: PROGRESSÃO de pena funciona mal por que é falha ou por que o estado não atende às exigências da lei?. Direção: Marcelo Canellas. Produção: Vera Souto. Edição: Joelson Maia. Técnicos: Paulo Martins e Jorge Sant'anna. Arte: Alexandre Beltran. Imagem: Lúcio Alves. FANTÁSTICO. REDE GLOBO. 6 dez. 2015. 15min47s. Disponível em: $<$ http://g1.globo.com/fantastico/noticia/2015/12/fantastico-ouve-especialistas-e-vitimas-sobreprogressao-de-pena.html>. Acesso em: 13 set. 2017. Trecho: 7min54s-8min22s.

115 Ibid., Trecho: $8 \min 53 \mathrm{~s}-9 \min 25 \mathrm{~s}$.

116 THOMPSON, Augusto. A questão penitenciária. 2.ed. Rio de Janeiro: Editora Forense, 1980. Parte II - Sugestões para uma Reforma Penal, Capítulo IV, Regime de Execução da Pena Prisional, IRRACIONALIDADE DO SISTEMA PROGRESSIVO, p. 143.

117 THOMPSON, Augusto. A questão penitenciária. 2.ed. Rio de Janeiro: Editora Forense, 1980. Parte II - Sugestões para uma Reforma Penal, Capítulo IV, Regime de Execução da Pena Prisional, ADOÇÃO DE UM SISTEMA REGRESSIVO, p. 145.
} 
que: condenados por crime comum progridem de regime após cumprir 1/6 (um sexto) da pena com bom comportamento carcerário ${ }^{118}$; já no caso de crimes hediondos, a Lei de Crimes Hediondos (Lei 8.072/90) excepciona a regra geral, subindo o critério objetivo como condição à concessão do mesmo benefício para o cumprimento de $2 / 5$ (dois quintos) da pena se não houver reincidência - circunstância que aumenta o patamar mínimo para 3/5 (três quintos) $)^{119}$.

A fixação do regime inicial da pena privativa de liberdade é estabelecida conforme os critérios do artigo 33 do Código Penal (DecretoLei $2.848 / 40)^{120}$, que possuem como parâmetro principal a quantificação da pena concreta cominada ao final da realização do método trifásico ${ }^{121} \mathrm{e}$ também as circunstâncias judiciais presentes no artigo 59 do Código Penal Brasileiro.

A leitura cega das orientações do $\S 2^{\circ}$ - quantum de pena - do artigo 33 do Código Penal Brasileiro tendencia a uma maior aplicação do regime inicial fechado, de maneira geral, na atuação dos magistrados, além de esvaziar completamente de sentido os ditames do $\S 3^{\circ}$ - circunstâncias judiciais - do mesmo dispositivo penal. A respeito dessa incoerência, Carlos

\footnotetext{
${ }^{118}$ Lei 7.210/84, art. 112. A pena privativa de liberdade será executada em forma progressiva com a transferência para regime menos rigoroso, a ser determinada pelo juiz, quando o preso tiver cumprido ao menos um sexto da pena no regime anterior e ostentar bom comportamento carcerário, comprovado pelo diretor do estabelecimento, respeitadas as normas que vedam a progressão.

${ }^{119}$ Lei 8.072/90, art. $2^{\circ}, \S 2^{\circ}$. A progressão de regime, no caso dos condenados aos crimes previstos neste artigo, dar-se-á após o cumprimento de $2 / 5$ (dois quintos) da pena, se o apenado for primário, e de $3 / 5$ (três quintos), se reincidente

${ }^{120}$ Lei 7.210/84, art. 110. O Juiz, na sentença, estabelecerá o regime no qual o condenado iniciará o cumprimento da pena privativa de liberdade, observado o disposto no artigo 33 e seus parágrafos do Código Penal.

${ }^{121}$ Decreto-Lei $2.848 / 40$, art. 33 , $\S 2^{\circ}$ - As penas privativas de liberdade deverão ser executadas em forma progressiva, segundo o mérito do condenado, observados os seguintes critérios e ressalvadas as hipóteses de transferência a regime mais rigoroso:

a) o condenado a pena superior a 8 (oito) anos deverá começar a cumpri-la em regime fechado;

b) o condenado não reincidente, cuja pena seja superior a 4 (quatro) anos e não exceda a 8 (oito), poderá, desde o princípio, cumpri-la em regime semiaberto;

c) o condenado não reincidente, cuja pena seja igual ou inferior a 4 (quatro) anos, poderá, desde o início, cumpri-la em regime aberto.

$\S 3^{\circ}$ - A determinação do regime inicial de cumprimento da pena far-se-á com observância dos critérios previstos no art. 59 deste Código.
} 
Raymundo Cardoso, ex-diretor da penitenciária Lemos Brito e desembargador aposentado, leciona que:

O $\S 2^{\circ}$ do artigo 33 do Código Penal é uma norma técnica que serve de parâmetro para o juiz. A fixação do regime inicial faz parte da fixação da pena, razão pela qual deve ser feita pelos mesmos critérios. Portanto, o princípio reitor dessa determinação se encontra, na realidade, no $\S^{\circ}$ do artigo 33 do Código Penal. Trata-se, dessa forma, na minha interpretação, de um ato discricionário vinculado em que o magistrado determinará o regime inicial independentemente da quantidade do tempo de pena. Assim, com o respaldo legal do artigo $33, \S 3^{\circ} \mathrm{c} / \mathrm{c}$ artigo 59, caput, ambos do Código Penal Brasileiro, pode-se, por exemplo, em um caso de roubo majorado pelo concurso de agentes, com o emprego de arma de apenas um deles, colocar no regime semiaberto o agente não armado considerando ser ele primário e de bons antecedentes -, apesar da pena imputada ultrapassar 8 anos; assim como também é possível firmar o regime fechado para um condenado a 4 anos de reclusão em que o juiz entenda - a partir da análise das circunstâncias judiciais - não ser a pena privativa de liberdade substituível por uma restritiva de direito. ${ }^{122}$ - Grifo Nosso.

Considerando todo o exposto nos capítulos anteriores, é correto afirmar que a filosofia do sistema progressivo oferece uma esquizofrenia, pois "o tratamento que dispensa se inicia com providenciar o agravamento do estado do paciente" ${ }^{123}$. Criticamente atenta Augusto Thompson para o fato de que,

Inicialmente, submete-se o condenado às terríveis condições dos depósitos de presos - enxovias onde a promiscuidade e a degradação atingem índices indescritíveis. Após período de tempo suficiente para arrasar-lhe a personalidade, suprimindo os predicados, maiores ou menores, que possuía na vida livre, é ele removido para a penitenciária de segurança. Para que não sobre qualquer resquício de dignidade, que haja resistido à primeira prova, impõe-se-lhe, na nova morada, ao nela entrar, um regime de dureza: durante três meses fica em isolamento total, trancado dia e noite. Em seguida, é-lhe permitido comunicar-se com os companheiros, porém privado de quaisquer outras amenidades ou favores. Se o paciente é prisonizado, adquirindo os valores predominantes na cadeia, assumindo um dos papéis que a sociedade dos cativos lhe oferece, então fica-lhe aberta a via para alcançar regalias gradativas e sucessivas. Caso a adaptação seja completa, terá até direito a ver diminuído o prazo de encarceramento, por meio de livramento condicional. Nessa hipótese, colocado em meio à sociedade livre, provavelmente fará tudo para voltar à prisão (...). Se o interno refuga a prisão, sofrerá um regime severo, cada vez mais duro, até que lhe seja quebrada a resistência contra a assimilação dos padrões da penitenciária. O sistema progressivo é algo, assim, como um médico que, diagnosticando no cliente um certo grau de enfermidade (pequeno, médio ou alto), começa o tratamento cuidando de agravar a doença até obter a morte do dito paciente e, depois de deixá-lo enterrado durante

\footnotetext{
122 CARDOSO, Carlos Raymundo. Entrevista concedida a Luisa de Araujo Tavares. 6 set. 2017. ${ }^{123}$ THOMPSON, Augusto. A questão penitenciária. 2.ed. Rio de Janeiro: Editora Forense, 1980. Parte II - Sugestões para uma Reforma Penal, Capítulo IV, Regime de Execução da Pena Prisional, IRRACIONALIDADE DO SISTEMA PROGRESSIVO, p. 144.
} 
algum tempo, para maior certeza do óbito, lança-se à tarefa de conseguir a cura do cadáver. ${ }^{124}$ - Grifo Nosso.

Dessa forma, já se havendo exaustivamente demonstrado que " $a$ penitenciária não tem nem pode ter efeito regenerador sobre o condenado" 125 , Thompson conclui que:

O critério rígido, amarrado demais ao quantum da pena para que se determine onde o condenado começará o seu cumprimento, não é feliz. De acordo com circunstâncias diversas, poder-se-ia estabelecer, para certos réus, que entrassem no sistema na casa dois ou três: condenado à prisão, o criminoso, inicialmente, seria colocado nas mais favoráveis condições de cumprimento de pena - sursis ou prisão-albergue. Ser-lhe-ia dada ciência de que, acaso sua conduta não correspondesse à expectativa, tais condições iriam sendo agravadas, progressivamente, podendo ir até a penitenciária fechada em regime rigoroso. Cabe deixar uma margem ampla apta para, diante dos fatos, possibilitar a adoção dessa ou daquela solução reclamada pelo caso concreto. ${ }^{126}$ - Grifo Nosso.

Na mesma diretriz, a socióloga Julita Lemgruber, especializada em segurança pública e sistema penitenciário, analisa que:

Mais de $40 \%$ dos presos no Brasil (entre 200 e 300 mil) ainda nem foram julgados. É evidente que, se fossem retirados da cadeia, ficaria mais fácil manejar os restantes. E, se desses que restaram, fosse possível manter presos apenas aqueles que apresentem algum risco à sociedade, o número cairia em dois terços. Os interessados em melhorar o sistema penitenciário têm de lutar para que não guarde pessoas que não deviam lá estar. Temos que encarar a crueldade desse sistema e admitir que só vai ser possível fazer alguma coisa quando houver um número muito pequeno de presos. Isso, sim, vai permitir a realização de algum tipo de trabalho que ajude o preso a, quando sair, encontrar algum outro caminho. $^{127}$ - Grifo Nosso.

Assim, denota-se, nos excertos acima, a propositura intuitiva de um sistema prisional simetricamente oposto ao então vigente: em vez de ter, como regra, o regime inicial mais rigoroso - pelo parâmetro básico de quantum de pena - e ir progredindo para os mais brandos (sistema progressivo); passar a considerar, como padrão, manter preliminarmente o apenado "em condições as mais semelhantes possíveis às existentes no

\footnotetext{
124 Ibid., p. 144-145.

125 THOMPSON, Augusto. A questão penitenciária. 2.ed. Rio de Janeiro: Editora Forense, 1980. Parte II - Sugestões para uma Reforma Penal, Capítulo IV, Regime de Execução da Pena Prisional, ADOÇÃO DE UM SISTEMA REGRESSIVO, p. 145.

126 Ibid., p. 147-148.

${ }^{127}$ LEMGRUBER, Julita. Apud CARMONA, Helena. Prisão é o maior entrave para ressocialização, indica pesquisa. Jornal da PUC, 5 maio 2017. Disponível em: <http://jornaldapuc.vrc.pucrio.br/cgi/cgilua.exe/sys/start.htm?infoid=5172\&sid=48 >. Acesso em: 28 out. 2017.
} 
mundo livre" ${ }^{" 128}$, tendo como principais referências as peculiaridades de cada caso concreto, e, se "revelasse, porventura, inaptidão, iria descendo, gradualmente, a escala do sistema"129 (sistema regressivo). Nesse sentido, Thompson exemplifica, fazendo menção a duas situações distintas:

(1) Se um indivíduo que sempre se mostrou adaptado ao meio social, onde tem sido útil, respeitado e respeitador, observando conduta exemplar, pratica um homicídio passional, que receba, a se considerar seu ato reprovabilíssimo, uma pena grave - suponhamos, quinze anos. Segundo o Código, teria de começar a pena numa penitenciária fechada, pelo único fato de ser ela superior a oito anos de reclusão. Ora, mas se revela aptidão para a prisão aberta; se - e nesse caso é inegável - não há, verdadeiramente, o que regenerar no agente, uma vez que o crime foi episódio isolado em sua vida; se, indo para um estabelecimento fechado, corre risco - ou há certeza - de que se submeterá a um processo de desadaptação à vida comunitária; por que não permitir que comece a pena através do sursis ou da prisão-albergue ou, pelo menos, da prisão aberta? A adoção do sistema regressivo é um imperativo lógico. ${ }^{130}$ - Grifo Nosso.

(2) Se um jovem participar de um roubo, através de ameaça exercida com emprego de arma, mas se se constata que o fez para dar vazão a um impulso aventuroso, característico da faixa etária, que seja condenado a dez anos de reclusão, já que é necessário dar sentido retributivo à pena, mas que se permita, se suas condições pessoais estão a aconselhar, que inicie a pena, senão em liberdade fiscalizada, pelo menos na prisão-albergue ou na prisão-aberta, porque remetê-lo diretamente para o estabelecimento fechado é decretar-lhe a perdição. Caso não aproveite a oportunidade, então que vá baixando na escala proposta. ${ }^{131}-$ Grifo Nosso.

Neste momento, é possível que se questione o fato de que as circunstâncias de cada caso em particular -em relação tanto aos aspectos pessoais do agente, como também aos atos em si - já são consideradas pelo juiz, no sistema atual, para a fixação do regime inicial, uma vez que observa os critérios previstos no artigo 59 do Código Penal Brasileiro ${ }^{132}$.

\footnotetext{
128 THOMPSON, Augusto. Op. cit., p. 146.

129 THOMPSON, Augusto. A questão penitenciária. 2.ed. Rio de Janeiro: Editora Forense, 1980. Parte II - Sugestões para uma Reforma Penal, Capítulo IV, Regime de Execução da Pena Prisional, ADOÇÃO DE UM SISTEMA REGRESSIVO, p. 151.

${ }^{130}$ Ibid., p. 150.

131 Ibid., p. 151.

${ }^{132}$ Decreto-Lei 2.848/40, art. 59 - O juiz, atendendo à culpabilidade, aos antecedentes, à conduta social, à personalidade do agente, aos motivos, às circunstâncias e consequências do crime, bem como ao comportamento da vítima, estabelecerá, conforme seja necessário e suficiente para reprovação e prevenção do crime:

I - as penas aplicáveis dentre as cominadas;

II - a quantidade de pena aplicável, dentro dos limites previstos;

III - o regime inicial de cumprimento da pena privativa de liberdade;

IV - a substituição da pena privativa da liberdade aplicada, por outra espécie de pena, se cabível.
} 
A inovação, na verdade, faz-se por uma mudança de pensamento na qual a prisão em regime fechado seja considerada uma exceção, ou seja, uma ferramenta utilizada em último caso - visto o grau de sua nocividade para a psiquê humana. Por esse motivo, o que iluminará com mais força o magistrado, nessa análise, será o critério subjetivo e não, como determina a lei, a pena concretamente cominada (critério objetivo).

Ainda no que concerne à crítica da superlotação nos presídios brasileiros, importante fazer alusão ao Projeto de Lei do Senado $n^{\circ}$ 513/2013, aprovado no dia 4 de outubro de 2017, que reforma a Lei de Execução Penal (Lei 7.210/84) para reverter tal quadro, viabilizando, de modo mais concreto e factível, a ressocialização do preso $^{133}$. Dentre as 200 (duzentas) alterações trazidas pelo referido projeto de lei, uma das mudanças formuladas e propostas é a possibilidade de cumprimento de pena em estabelecimentos da sociedade civil, trocando em miúdos, nas conhecidas APACs, que serão abordadas e analisadas a seguir.

\subsection{O MÉTODO DA ASSOCIAÇÃO DE PROTEÇÃO E ASSISTÊNCIA AOS CONDENADOS (APAC)}

A orientação de um sistema com a lógica invertida trabalha ainda com a possibilidade da incidência do regime fechado para aqueles indivíduos que não possuam "aptidão"134 para regimes menos rudes. Como já validado nos capítulos anteriores, "a pena de prisão pune, talvez intimide, mas não recupera" ${ }^{135}$. Diante de tal premissa, e sendo inevitável a sua aplicação, busca-se então um ambiente prisional dotado de condições que viabilizem viver com dignidade.

\footnotetext{
${ }^{133}$ PORTAL DO CONSELHO NACIONAL DE JUSTIÇA - Revisão da LEP reforça ações do CNJ para fim de superlotação em presídios. Disponível em: <http://www.cnj.jus.br/noticias/cnj/80826revisao-da-lep-reforca-acoes-do-cnj-para-o-fim-da-superlotacao-nos-presidios $>$. Acesso em: 17 out. 2017.

${ }^{134}$ THOMPSON, Augusto. A questão penitenciária. 2.ed. Rio de Janeiro: Editora Forense, 1980. Parte II - Sugestões para uma Reforma Penal, Capítulo IV, Regime de Execução da Pena Prisional, ADOÇÃO DE UM SISTEMA REGRESSIVO, p. 150.

${ }^{135}$ Ibid., p. 147.
} 
A Associação de Proteção e Assistência aos Condenados (APAC), criada em 1972, cuja sede no Brasil está localizada na cidade de Itaúna, em Minas Gerais, traz um modelo de humanização do sistema penitenciário. Trata-se de uma metodologia que, muito embora não desconsidere a finalidade retributiva da pena prisional, se preocupa em recuperar os custodiados, reintegrando-os socialmente de modo a evitar a reincidência dos mesmos na prática de delitos.

A APAC é uma organização social sem fins lucrativos que administra 44 (quarenta e quatro) presídios em 6 (seis) estados brasileiros; trabalha com os 3 (três) regimes de cumprimento de pena; e os presos são considerados, na verdade, recuperantes. Na reportagem produzida pelo Fantástico, já supracitada, os jornalistas visitam a filial de Itaúna, e o recuperante Fernando Domingues explica a organização das celas:

Em cada cela ficam quatro recuperantes. Cada um tem o seu armário para guardar as roupas; cada um tem a sua cama, o seu colchão, o seu travesseiro; há um ventilador coletivo e o piso é de azulejo. O banheiro de todas as celas possuem ( $\mathrm{sic}$ ) um armário com quatro lugares para cada um guardar seus produtos de higiene, um vaso sanitário e o chuveiro é elétrico. ${ }^{136}$

Uma prisão onde não há violência: a solitária virou capela e come-se dieta balanceada com garfo e faca. O diretor executivo, Valdeci Antônio Ferreira, revela que

Todas as chaves estão nas mãos dos recuperantes. Não existem policiais armados, não existem agentes penitenciários, não existem armas na APAC. No método APAC, a disciplina é extremamente rigorosa, onde ( sic) eles são obrigados a trabalhar, são obrigados a estudar. Hoje, um preso na APAC custa um terço do valor que se é pago (sic) no sistema prisional comum. Nunca registramos rebeliões, atos de violência, suicídios, mortes e nós já estamos há mais de quatro mil dias sem fugas do regime fechado. ${ }^{137}$ - Grifo Nosso.

\footnotetext{
${ }^{136}$ DOMINGUES, Fernando. In: PROGRESSÃO de pena funciona mal por que é falha ou por que o estado não atende às exigências da lei?. Direção: Marcelo Canellas. Produção: Vera Souto. Edição: Joelson Maia. Técnicos: Paulo Martins e Jorge Sant'anna. Arte: Alexandre Beltran. Imagem: Lúcio Alves. FANTÁSTICO. REDE GLOBO. 6 dez. 2015. 15min47s. Disponível em: $<$ http://g1.globo.com/fantastico/noticia/2015/12/fantastico-ouve-especialistas-e-vitimas-sobreprogressao-de-pena.html>. Acesso em: 13 set. 2017. Trecho: 11min36s-12min04s.

${ }^{137}$ FERREIRA, Valdeci Antônio. In: PROGRESSÃO de pena funciona mal por que é falha ou por que o estado não atende às exigências da lei?. Direção: Marcelo Canellas. Produção: Vera Souto. Edição: Joelson Maia. Técnicos: Paulo Martins e Jorge Sant'anna. Arte: Alexandre Beltran. Imagem: Lúcio Alves. FANTÁSTICO. REDE GLOBO. 6 dez. 2015. 15min47s. Disponível em: $<$ http://g1.globo.com/fantastico/noticia/2015/12/fantastico-ouve-especialistas-e-vitimas-sobreprogressao-de-pena.html >. Acesso em: 13 set. 2017. Trecho: 12min07s-12min35s.
} 
Interessante se faz, neste momento, conhecer a história de Maurício Alves, condenado a 19 (dezenove) anos por roubo majorado pelo emprego de arma de fogo, para perceber que, por caminhos alternativos ao sistema prisional asfixiante, pode-se alcançar a tão buscada regeneração:

Eu vou contar a história de um rapaz: cansado de ver o pai discutindo e agredindo a mãe, ele decide sair de casa e vai morar nas ruas. Se envolve com as drogas muito cedo, se envolve em muitas brigas e em uma delas leva 14 (quatorze) tiros de pistola, sendo que o último acerta na cabeça. Ele não morre, sai do hospital e volta para o mesmo ponto que ele estava. Dentro dele está alimentando somente sentimentos de ódio e vingança, até que vai preso em regime fechado. Pelo sistema penitenciário ele conhece outras pessoas, vai vivendo e se aprofundando cada vez mais no mundo do crime. Há possibilidade de ressocialização? Nesse sistema, lógico que não. Então, ele entra em progressão de pena e tudo muda: em contato com uma metodologia mais humanizada - como a da APAC -, começa a desenvolver algo no coração dele e decide se tornar um defensor público. Faz vestibular e passa no vestibular, sendo agora um aluno do $5^{\circ}$ (quinto) período do curso de Direito. Esse sou eu, essa é a minha história: eu morei nas ruas, eu fiquei preso e, hoje, estou dentro de uma faculdade, sou chamado de "doutor". Não podemos deixar de acreditar que o ser humano é bom. ${ }^{138}$ - Grifo Nosso.

O fragmento acima narra, portanto, um resgate, ilustrando que o instituto da reeducação pode ser ressuscitado e, assim, deixe de se resumir a mera utopia falaciosa.

\subsection{EXPANSÃO NAS HIPÓTESES DE CABIMENTO DAS PENAS RESTRITIVAS DE DIREITO}

Restou demonstrado, no decorrer de todo este trabalho, que "quanto mais tempo atrás das grades, distante da dinâmica do mundo real, mais profunda a desadaptação e mais previsível o retorno à criminalidade"139. Nesse sentido, para maior efetividade da reinserção do apenado na comunidade livre, é necessário - como já aludido nas propostas anteriores -

\footnotetext{
${ }^{138}$ ALVES, Maurício. In: PROGRESSÃO de pena funciona mal por que é falha ou por que o estado não atende às exigências da lei?. Direção: Marcelo Canellas. Produção: Vera Souto. Edição: Joelson Maia. Técnicos: Paulo Martins e Jorge Sant'anna. Arte: Alexandre Beltran. Imagem: Lúcio Alves. FANTÁSTICO. REDE GLOBO. 6 dez. 2015. 15min47s. Disponível em: <http://g1.globo.com/fantastico/noticia/2015/12/fantastico-ouve-especialistas-e-vitimas-sobreprogressao-de-pena.html >. Acesso em: 13 set. 2017. Trecho: 13min45s-15min40s.

${ }^{139}$ CARVALHO FILHO, Luis Francisco. A Prisão. São Paulo: PubliFolha, 2002, p. 71.
} 
que a privação da liberdade apenas seja utilizada em último caso, em que os demais recursos não se demonstrem eficientes, demandando-se, assim, maior preponderância de penas alternativas à prisão, como é o caso das restritivas de direito.

\section{Em Penas e medidas alternativas à prisão, Luiz Flávio Gomes} enumera o que entende serem os propósitos legais:

1) Diminuir a superlotação dos presídios, sem perder de vista a eficácia preventiva geral e especial da pena;

2) Reduzir os custos do sistema penitenciário;

3) Favorecer a ressocialização do autor pelas vias alternativas, evitando-se o pernicioso contato carcerário, bem como a decorrente estigmatização;

4) Reduzir a reincidência;

5) Preservar, sempre que possível, os interesses da vítima. ${ }^{140}$ - Grifo Nosso.

Considerando tais finalidades, o ministro Gilmar Mendes, na abertura do IV Congresso Nacional de Execução de Penas e Medidas Alternativas, realizado em Manaus, expõe que,

De acordo com o Ministério da Justiça, somente $60 \%$ dos encarcerados cumprem integralmente a pena estabelecida - contra mais de $90 \%$ que receberam penas alternativas. Além disso, mais de $80 \%$ das pessoas que estão nos presídios são reincidentes. Essa taxa baixa para menos de $10 \%$ em se tratando do sistema alternativo. ${ }^{141}$

Desse modo, mostra-se fundamental uma revisão do ordenamento jurídico, com maior atenção ao artigo 44 do Código Penal Brasileiro ${ }^{142}$ - que

${ }^{140}$ GOMES, Luiz Flávio. Penas e medidas alternativas à prisão. 2.ed. São Paulo: Revista dos Tribunais, 2000, p. 96.

${ }^{141}$ MENDES, Gilmar. País discute eficácia do cumprimento de penas alternativas. In: Ministério da Justiça, 2008. Disponível em: 〈http://www.mj.gov.br〉. Acesso em: 5 out. 2017.

142 Decreto-Lei $2.848 / 40$, art. 44. As penas restritivas de direitos são autônomas e substituem as privativas de liberdade, quando:

I - aplicada pena privativa de liberdade não superior a quatro anos e o crime não for cometido com violência ou grave ameaça à pessoa ou, qualquer que seja a pena aplicada, se o crime for culposo; II - o réu não for reincidente em crime doloso;

III - a culpabilidade, os antecedentes, a conduta social e a personalidade do condenado, bem como os motivos e as circunstâncias indicarem que essa substituição seja suficiente.

$\S 1^{\circ}$ (VETADO)

$\S 2^{\circ} \mathrm{Na}$ condenação igual ou inferior a um ano, a substituição pode ser feita por multa ou por uma pena restritiva de direitos; se superior a um ano, a pena privativa de liberdade pode ser substituída por uma pena restritiva de direitos e multa ou por duas restritivas de direitos.

$\S 3^{\circ}$ Se o condenado for reincidente, o juiz poderá aplicar a substituição, desde que, em face de condenação anterior, a medida seja socialmente recomendável e a reincidência não se tenha operado em virtude da prática do mesmo crime.

$\S 4^{\circ}$ A pena restritiva de direitos converte-se em privativa de liberdade quando ocorrer o descumprimento injustificado da restrição imposta. No cálculo da pena privativa de liberdade a 
traz as condições necessárias para a substituição da pena privativa de liberdade por uma restritiva de direitos. O intuito é tanto promover a ampliação da aplicabilidade das penas restritivas de direito, como também estabelecer um mais efetivo sistema de controle da execução, de forma a conferir maior credibilidade social a esse tipo de sanção, para que assim os escopos de Luiz Flávio Gomes supracitados sejam concretamente viabilizados e alcançados.

Analisando o disposto no artigo do Código Penal supramencionado, é possível perceber que a legislação brasileira, pelo critério quantitativo da pena - não superior a 4 (quatro) anos - possibilita a substituição da pena privativa de liberdade em restritiva de direito nos crimes de pequeno e médio potencial ofensivo não cometidos com violência ou grave ameaça, o que corresponde a "uma clientela que nunca foi a da prisão, a responsável pela superlotação dos complexos penitenciários brasileiros" ${ }^{143}$. Nessa mesma perspectiva, os pesquisadores responsáveis pelo Levantamento Nacional de Execução de Penas Alternativas, realizado pelo ILANUD, concluíram que:

A pena alternativa, tal como é prevista no ordenamento brasileiro e aplicada no sistema de justiça, não cumpre a função de "esvaziar as prisões", já que o perfil do indivíduo apenado por pena restritiva de direito, especialmente quanto ao delito cometido, não se identifica com o da população carcerária. Considerando-se esses elementos, conclui-se que os indivíduos que são condenados à pena privativa de liberdade e que têm realmente a sua pena substituída pela pena restritiva de direitos, em verdade, não seriam apenados com a prisão, dada a pré-existência de outros institutos, como o sursis, que evitariam a sua prisão. ${ }^{144}$ - Grifo Nosso.

Nesse sentido, então, constata-se que, na atual conjuntura, a forma de aplicação das penas restritivas de direito faz que as mesmas não exerçam, de maneira efetiva, a sua função de meios alternativos ao cárcere, sendo apenas,

\footnotetext{
executar será deduzido o tempo cumprido da pena restritiva de direitos, respeitado o saldo mínimo de trinta dias de detenção ou reclusão.

$\S 5^{\circ}$ Sobrevindo condenação a pena privativa de liberdade, por outro crime, o juiz da execução penal decidirá sobre a conversão, podendo deixar de aplicá-la se for possível ao condenado cumprir a pena substitutiva anterior.

${ }^{143}$ AZEVÊDO, Jackson C. de. Reforma e contra-reforma penal no Brasil: uma ilusão que sobrevive. Florianópolis: OAB/SC, 1999, p. 48.

${ }^{144}$ INSTITUTO LATINO-AMERICANO DAS NAÇÕES UNIDAS PARA PREVENÇÃO DO DELITO E TRATAMENTO DO DELINQUENTE (ILANUD/BRASIL). Levantamento Nacional sobre Execução de Penas Alternativas, 2006.
} 
como bem alude Foucault ao analisar tal funcionamento, "um remanejo do poder de castigar; não punir menos, mas punir melhor" ${ }^{145}$.

\subsection{IMPLEMENTAÇÃO E PREDOMINÂNCIA DE UMA JUSTIÇA RESTAURATIVA BASEADA NO USO DE FERRAMENTAS AUTOIMPLICATIVAS}

Considerando toda a análise desencadeada neste trabalho, resta claro que, no Brasil, vigora um sistema criminal predominantemente retributivo, calcado em uma lógica pedagógica punitiva, muito bem descrita pelo juiz Egberto Penido, coordenador do Núcleo de Estudos de Justiça Restaurativa da Escola Paulista da Magistratura:

Se alguém ofendeu (acarretou dor) a uma pessoa, deve-se impor a tal pessoa uma sanção (uma "dor") para que reflita sobre o mal feito e fique desestimulado a voltar a infringir a norma legal; além disso, tal dinâmica serve, ainda, de exemplo, para que outros não se sintam estimulados em infracionar. Entende-se que uma vez violada uma lei, o Estado - que possui o monopólio legítimo do uso da força intervém em prol da sociedade, cuja existência foi atingida com a ofensa. A relação, portanto, é estabelecida entre o Estado e o réu. O olhar é para o passado, calcado preponderantemente em depoimentos subjetivos de testemunhas. Visa-se, desta forma, estabelecer a culpa do réu e, pelas mãos de uma terceira pessoa (o Juiz de Direito - representante do Estado), se impõe uma sanção. Nesta dinâmica, a responsabilização é individual, passiva e ditada de modo hierárquico e vertical. Tal lógica está calcada no exercício de poder de dominação que se faz "sobre o outro" e não "com o outro". Esta visão torna o ofensor, a vítima e a comunidade em "coisas" e não em "sujeitos", os quais não têm voz; invariavelmente, não têm suas necessidades atendidas, e são incluídos em dinâmicas que acirram suas fragilidades e não permitem o empoderamento. ${ }^{146}$ - Grifo Nosso.

Nota-se, portanto, que o engendramento do sistema acaba por despersonalizar os indivíduos em sua dignidade, uma vez que, diante do

\footnotetext{
${ }^{145}$ FOUCAULT, Michel. Vigiar e punir: nascimento da prisão. Tradução: Raquel Ramalhete. 42.ed. Petrópolis: Editora Vozes, 2014. Segunda Parte: Punição, Capítulo I - A punição generalizada, p. 93. ${ }^{146}$ ALMEIDA, Tania; PELAJO, Samantha; JONATHAN, Eva (Coord.). Mediação de conflitos: para iniciantes, praticantes e docentes. 1.ed. Salvador: Editora JusPodivm, 2016. PARTE II: para praticantes, Capítulo 7, Justiça Restaurativa, p. 680.
} 
cometimento de um crime, "o foco é na lei que foi rompida"147. Nesse sentido, pontua Marcos Rolim:

Qualquer que seja o olhar sobre o funcionamento do Sistema de Justiça Criminal em todo o mundo haverá de recolher, pelo menos, dúvidas muito consistentes a respeito de sua eficácia. Pode-se, com razão, argumentar que a experiência concreta realizada com a justiça criminal na modernidade está marcada por um conjunto de promessas não cumpridas que vão desde a alegada função dissuasória ou intimidadora das penas até a perspectiva da ressocialização. Uma abordagem mais crítica não vacilaria em apontar a falência estrutural de um modelo histórico. Estamos, afinal, ao que tudo indica, diante de um complexo e custoso aparato institucional que, em regra, não funciona para responsabilização dos infratores, não produz justiça, nem se constitui em um verdadeiro sistema. Quando se depara com delitos de pequena gravidade, o direito penal é demasiado; quando se depara com crimes graves, parece inútil. ${ }^{148}$ - Grifo Nosso.

\section{Em uma mesma diretriz posiciona-se Howard Zehr:}

Os ofensores violam a lei estatal e devem ser punidos. O Estado se encarrega. Tudo isto nos parece bastante natural e inevitável. Como certeza, o paradigma retributivo vem nos acompanhando há muito tempo. Seguramente ele representa uma melhoria significativa em relação ao que era praticado antes. Sem dúvida ele é o que deve ser. Mas o modelo retributivo de justiça não é a única forma que concebemos a justiça no Ocidente. Com efeito, outros modelos de justiça predominaram ao longo da maior parte de nossa história. Somente nos últimos séculos é que o paradigma retributivo monopolizou a nossa visão. $\mathbf{E}$ a vitória desse paradigma tampouco representa necessariamente uma melhoria. Interpretar a história como progresso é uma falácia comum. Vemos os desenvolvimentos mais recentes como melhorias quase que inevitáveis em relação ao passado. Mas o presente não está fatalmente ligado ao passado, nem representa sempre um progresso em relação a este. ${ }^{149}$ - Grifo Nosso.

Por sua vez, a justiça restaurativa é dotada de lógica distinta de foco e busca. Trata-se de uma "ética aplicada" 150 que trabalha com a "responsabilização coletiva e participativa" ${ }^{151}$, uma vez que enxerga a convivência entre as pessoas como um sistema complexo e interligado: cada

\footnotetext{
${ }^{147}$ ALMEIDA, Tania; PELAJO, Samantha; JONATHAN, Eva (Coord.). Mediação de conflitos: para iniciantes, praticantes e docentes. 1.ed. Salvador: Editora JusPodivm, 2016. PARTE II: para praticantes, Capítulo 7, Justiça Restaurativa, p. 680.

${ }^{148}$ ROLIM, Marcos. Justiça restaurativa: para além da punição. In: Justiça Restaurativa: um caminho para os Direitos Humanos. Porto Alegre: Instituto de Acesso à Justiça, 2004, p. 7.

${ }^{149}$ ZEHR, Howard. Trocando as lentes: um novo foco sobre o crime e a justiça. São Paulo: Editora Palas Athena, 2005, p. 93.

${ }^{150}$ PASSOS, Celia; BATTAGLiA, Maria do Céu; PELAJO, Samantha. Entrevista concedida a Luisa de Araujo Tavares. 2 out. 2017.

${ }^{151}$ ALMEIDA, Tania et al. Op. cit., p. 680.
} 
ato ofensivo simboliza um "esgarçamento na teia de relações" 152 , possuindo, dessa forma, inúmeras causas e gerando, por conseguinte, múltiplos efeitos e desdobramentos. Corresponde a um "modo de ser e estar no mundo" 153 , com valores como, por exemplo, igualdade de preocupação tanto com o autor do ato como também com o receptor do ato; dilui-se, assim, a noção cristalizada de "agressor" e "vítima" que, no modelo penal retributivo, atua como uma tarja estigmatizante.

Tais valores, então, irão originar na sociedade princípios norteadores que, em uma abordagem metafórica de Celia Passos, "servirão como bússolas que guiarão o modo de se situar no mundo"154, visando à tomada de consciência e à responsabilização da dimensão do ato praticado - por parte de todos - a partir da autoimplicação. Howard Zehr diferencia as estruturas retributiva e restaurativa com as seguintes definições:

Justiça Retributiva: O crime é uma violação contra o Estado, definida pela desobediência à lei e pela culpa. A justiça determina a culpa e inflige dor no contexto de uma disputa entre ofensor e Estado, regida por regras sistemáticas. ${ }^{155}$

Justiça Restaurativa: O crime é uma violação de pessoas e relacionamentos. Ele cria a obrigação de corrigir os erros. A justiça envolve a vítima, o ofensor e a comunidade na busca de soluções que promovam reparação, reconciliação e segurança. ${ }^{156}$

Realizadas tais distinções, importante se faz, neste momento do trabalho, expor o relato de uma mesma história contada, a partir de "dois fluxos de encaminhamentos possíveis" ${ }^{\prime 57}$, por Egberto Penido: uma versão segue um viés punitivo-retributivo, enquanto a outra se desencadeia seguindo um eixo restaurativo. Versa sobre uma briga entre alunos de uma escola por conta de prática de bullying:

\footnotetext{
${ }^{152}$ ALMEIDA, Tania; PELAJO, Samantha; JONATHAN, Eva (Coord.). Mediação de conflitos: para iniciantes, praticantes e docentes. 1.ed. Salvador: Editora JusPodivm, 2016. PARTE II: para praticantes, Capítulo 7, Justiça Restaurativa, p. 680.

${ }^{153}$ PASSOS, Celia; BATTAGLIA, Maria do Céu; PELAJO, Samantha. Entrevista concedida a Luisa de Araujo Tavares. 2 out. 2017.

${ }^{154}$ PASSOS, Celia; BATTAGLIA, Maria do Céu; PELAJO, Samantha. Entrevista concedida a Luisa de Araujo Tavares. 2 out. 2017.

${ }^{155}$ ZEHR, Howard. Trocando as lentes: um novo foco sobre o crime e a justiça. São Paulo: Editora Palas Athena, 2005, p. 170.

156 Ibid., p. 171.

${ }^{157}$ ALMEIDA, Tania et al. Op. cit., p. 672.
} 
Nesta cena imaginária (ou talvez nem tanto) o aluno chamou sua colega de "choquito" por conta das características físicas dela, especialmente de pele; por sua vez ela (que assim já vinha sendo chamada há algum tempo), neste dia, em vez de "engolir o sapo", reagiu violentamente agredindo este garoto (inclusive batendo a cabeça dele contra um armário, o que provocou um corte com sangramento). ${ }^{158}$

\section{Pela lógica punitiva:}

Após a troca de agressões entre os alunos, houve a lavratura do Boletim de Ocorrência em desfavor da adolescente e este expediente policial foi enviado para o "Sistema de Justiça" e distribuído para um Promotor de Justiça que, com base no Estatuto da Criança e do Adolescente, promoverá a oitiva informal da adolescente e, eventualmente, oferecerá uma representação. Recebida a representação, instaurada a ação judicial socioeducativa com seu regular processamento, se os fatos durante a instrução do feito restarem demonstrados, pode-se supor que seria aplicada à aluna uma medida socioeducativa de advertência ou de prestação de serviços à comunidade, ou, ainda, de liberdade assistida. Neste procedimento, muito dificilmente haverá alguma reflexão por parte da adolescente do valor da norma que ela rompeu. Para ela, o agressor é o aluno que lhe chamou pelo nome depreciativo e discriminatório; logo, dentro da sua lógica, ela teria agido em "legítima defesa". Consequentemente, ao lhe ser aplicada uma medida socioeducativa, muito provavelmente se sentirá duplamente vitimizada, dificilmente realizará qualquer reflexão sobre sua conduta e não se responsabilizará, assim, de modo efetivo; além disso, as causas que a levaram a agir assim permanecerão sem serem trabalhadas; tampouco haveria qualquer ação visando a reparação do dano que causou. Por fim, como a ciência da vitimologia vem apontando que aquele que se vê como vítima, ao não elaborar seus sentimentos, suas dúvidas, suas necessidades, passa a ter uma probabilidade alta de voltar a agir de modo violento. Na canhestra postura punitiva se entende que a culpa é da aluna que não controlou suas emoções e violou uma norma disciplinar e legal. Em verdade, "não resolve e não transforma" e não leva a qualquer responsabilização; ao contrário, em busca de um culpado para punir, acaba por retroalimentar o ciclo de violência a médio e longo prazo. ${ }^{159}$ - Grifo Nosso.

O filme $O$ Apartamento, de produção iraniana, retrata como a não elaboração e suprimento das necessidades geradas a partir do dano causado ensejam a escalada do conflito, retroalimentando o ciclo de violência ${ }^{160}$, como já supramencionado. Na história, um casal de atores se muda para um novo apartamento, onde a esposa é brutalmente violentada. Diante do ocorrido, forma-se uma crise: Rana, a vítima, entra em depressão e se recusa a ir à polícia, decidindo esquecer o ataque sofrido, sem qualquer exposição;

\footnotetext{
${ }^{158}$ ALMEIDA, Tania; PELAJO, Samantha; JONATHAN, Eva (Coord.). Mediação de conflitos: para iniciantes, praticantes e docentes. 1.ed. Salvador: Editora JusPodivm, 2016. PARTE II: para praticantes, Capítulo 7, Justiça Restaurativa, p. 671.

${ }^{159}$ Ibid., p. 672-673.

${ }^{160}$ Ibid., p. 673.
} 
Emad, seu marido, por sua vez, entra em uma obsessão para descobrir - por conta própria - quem invadiu sua casa e agrediu sua esposa.

Após muita investigação e procura, Emad descobre o autor do estupro - um senhor muito idoso - e, movido por muita mágoa e ressentimento, decide-se por destruir o agressor diante de sua família: Emad atrai o homem para sua antiga morada e o mantém em cárcere privado, condicionando a liberdade daquele a relatar a sua esposa, filha e genro o crime que cometeu. Rana, por sua vez, discorda da humilhação à qual Emad deseja e planeja submeter aquele senhor; pede que o marido o libere e ameaça terminar o casamento caso ele siga com seu plano de vingança. Pressionado e atormentado psicologicamente, o senhor acaba passando mal do coração e é levado para o hospital.

Denota-se, dessa forma, que necessário fazer um trabalho de ressignificação não somente com o autor do crime, mas também com a vítima e todas as pessoas, direta e indiretamente, atingidas pela ofensa cometida. Trata-se de uma atuação multilateral para que, assim, o conflito seja superado e transformado de maneira efetiva. Tal objetivo é demonstrado na resolução, pela via restaurativa, da briga entre os alunos já supracitada:

Supondo que nesta escola houvesse um projeto de Justiça Restaurativa em desenvolvimento. Assim, as pessoas envolvidas poderiam procurar os responsáveis pela implementação do mencionado projeto e solicitar a realização de um círculo restaurativo. No dia do encontro restaurativo, estiveram presentes a aluna, com sua genitora; o aluno, com seu genitor; dois representantes do "grêmio escolar" e um amigo de cada aluno; um representante do Conselho Tutelar; um representante da escola; além do facilitador restaurativo (guardião do círculo). Ou seja: estavam presentes no círculo, as pessoas direta e indiretamente envolvidas/afetadas no evento, bem como pessoas que poderiam dar apoio aos atingidos e, ainda, aquelas que poderiam contribuir para que atos daquela natureza não voltassem a ocorrer. Todos compareceram espontaneamente. Nos círculos restaurativos, há uma ordenação na comunicação a ser observada para que haja um efetivo entendimento do que ocorreu, bem como do "porque ocorreu", o que se pode fazer para reparar o dano e impedir que aquilo volte a ocorrer. De modo estruturado e seguindo um fluxo previamente acordado, há a construção conjunta de um processo de conscientização coletiva visando uma efetiva responsabilização tanto de quem lesionou, bem como de todos que contribuíram (por omissão ou não) para que o mal feito ocorresse, ou de todos que podem transformar as condições que geraram a ofensa. Nesta história, assim que a aluna começou a falar no círculo restaurativo, ela trouxe toda sua dor em ser chamada constantemente de "choquito". O aluno, ao ouvir este relato "sentido", foi se deparando com as consequências se suas ações; não tinha ideia da dor gerada por sua conduta. A aluna, ao avançar em sua fala, aponta para uma situação ainda mais delicada em sua casa, pois o padrasto dela 
também lhe chamava, em algumas ocasiões, de "choquito" e havia algo ali que precisava ser investigado. O Coordenador Pedagógico, que antes entendia que estava diante de uma aluna "irascível/belicosa", revisitou a forma como "via" a aluna. Além disso, refletiu sobre a responsabilidade da escola neste evento. A genitora da aluna também elaborou suas reflexões acerca de sua conduta em relação a sua filha e a seu companheiro. Continuando, quando foi a vez [de o] aluno falar, este começou a chorar, pois, como tinha "apanhado" de uma menina perante seus colegas, passou a ser chamado de "mariquinha/mulherzinha". Era muito provável que em pouco tempo, para mostrar que não era "mariquinha coisa nenhuma", ele se envolvesse em uma briga. Com o envolvimento de todos, foi elaborado um plano de ações, quebrando o ciclo de violência com a transformação do conflito. ${ }^{161}$ - Grifo Nosso.

\section{O convite à autoimplicação e consequente responsabilização}

possibilita a mudança, não retirando do autor do dano, da infração ou do crime a sua dignidade e dimensão humana, por mais grave que tenha sido a ação cometida. Nas palavras de William Ury, "se pudéssemos ler a história secreta dos nossos inimigos, encontraríamos, nas tristezas e nos sofrimentos de cada um deles, razões suficientes para desarmar toda a hostilidade"162. Diversamente das dinâmicas punitivas, "não se deve tornar a pessoa um objeto e, de modo estanque, defini-la apenas pelo momento de uma ação determinada, sem transformação" ${ }^{\text {"163 }}$. Não se trata de uma tarefa fácil:

Olhar para as consequências de suas ações; para a eventual desestrutura familiar; entrar em contato com emoções e sentimentos; não é uma tarefa confortável. Em verdade, é mais fácil "cumprir uma prestação de serviços à comunidade" do que refletir sobre o valor da norma que foi rompida e entender porque escolheu agir assim. É mais fácil "levar uma suspensão" do que entrar em contato com a dor da vítima. É mais fácil "pagar uma cesta básica" do que reparar efetivamente os prejuízos que ocasionou. Guardadas as devidas proporções, é mais fácil cumprir uma pena e se sentir "zerado" do que efetivamente responder - se responsabilizar de modo ativo - pelas causas e consequências de sua ação. Se o objetivo do Sistema de Justiça não é vingar/retaliar (se já ultrapassamos a "Lei de Talião"), mas responsabilizar, o caminho da punição não tem proporcionado, na maioria dos casos, a responsabilização e a mudança do comportamento a médio e longo prazo. ${ }^{164}$ - Grifo Nosso.

\footnotetext{
${ }^{161}$ ALMEIDA, Tania; PELAJO, Samantha; JONATHAN, Eva (Coord.). Mediação de conflitos: para iniciantes, praticantes e docentes. 1.ed. Salvador: Editora JusPodivm, 2016. PARTE II: para praticantes, Capítulo 7, Justiça Restaurativa, p. 675-676.

${ }^{162}$ URY, William. Como chegar ao SIM com você mesmo: o primeiro passo em qualquer negociação, conflito ou conversa difícil. Recurso Digital. Rio de Janeiro: Editora Sextante, 2015. Capítulo 5, Respeite os Outros, Coloque-se no Lugar do Outro, pos. 1157 de 1923.

${ }^{163}$ ALMEIDA, Tania et al. Op. cit., p. 675.

${ }^{164}$ Ibid., p. 676.
} 
Em um processo restaurativo, mesmo diante de episódios extremamente violentos, não se deixa de reconhecer o criminoso como ser humano. A história de Azim Khamisa, contada por William Ury em seu livro Como chegar ao SIM com você mesmo, comprova a possibilidade - e o consequente sucesso - da adoção de uma postura respeitosa com o agressor, apesar de toda a dor:

Lembro-me da história de Azim Khamisa, um empresário americano cujo filho de 20 anos, Tariq, foi assassinado por um membro de uma gangue. Tariq estudava durante o dia e trabalhava à noite, entregando pizzas. Certa vez, ele chegou à porta de um apartamento e foi recebido por um garoto de 14 anos, chamado Tony, que pegou a pizza e atirou em Tariq. Era um ritual de entrada na gangue. "Quando recebi o telefonema informando que Tariq estava morto, foi como se minha alma tivesse abandonado meu corpo, tamanha era a dor", disse Azim, numa entrevista em que descreveu como se sentiu ao ouvir a notícia. "Foi como uma bomba nuclear explodindo em meu coração (...). Nas semanas seguintes, sobrevivi graças a orações, e logo recebi a bênção do perdão, chegando à conclusão de que havia vítimas dos dois lados da arma". Azim procurou o avô e tutor de Tony, Ples Felix. Profundamente comovido com o gesto de Azim, Ples aceitou sua oferta de perdão. "Tentei convencer Tony a se responsabilizar por suas ações, a atenuar a dor e o mal que tinha causado à família Khamisa", explicou Ples. "Ele desabou e chorou. 'Sinto muito', soluçou. Abracei-o e tentei consolá-lo. No dia seguinte, todos esperavam que Tony listasse suas justificativas, mas meu neto não conteve a emoção e o remorso, declarando-se culpado e implorando o perdão do Sr. Khamisa". A escolha corajosa de Azim ao perdoar permitiu que Tony assumisse a responsabilidade por suas ações e sentisse a dor da culpa e do remorso em vez de sufocar seus sentimentos. O processo de cura de Azim se aprofundou ao incluir Ples e Tony. Juntos, Azim e Ples passaram a dar palestras em escolas para convencer os jovens a não usar a violência e criaram uma fundação para promover a causa. Azim foi convidado a fazer apresentações em todo o país, inclusive na Casa Branca. Cinco anos depois do assassinato, Azim visitou Tony na prisão e o convidou para trabalhar na fundação, quando fosse libertado. Tony disse ao avô: "Azim é um homem especial. Matei seu único filho e, mesmo assim, ele foi capaz de conversar comigo, me dar força e ainda me oferecer um emprego". Mesmo ao sofrer uma violência extrema, Azim optou por repudiar a vingança e cultivar o respeito, reconhecendo Tony, o assassino de Tariq, como ser humano. Sem ser condescendente com o crime, ele preferiu perdoar Tony e incluir tanto ele quanto o avô no esforço comum para combater a violência entre os jovens, que custara a vida do seu filho. Quando o conheci, ele era um homem vibrante, que irradiava energia. ${ }^{165}$ - Grifo Nosso.

Consubstancia-se em uma mudança de paradigma viável no que concerne à concepção de justiça, mas que demanda tempo e cuidado.

\footnotetext{
${ }^{165}$ URY, William. Como chegar ao SIM com você mesmo: o primeiro passo em qualquer negociação, conflito ou conversa difícil. Recurso Digital. Rio de Janeiro: Editora Sextante, 2015. Capítulo 5, Respeite os Outros, Coloque-se no Lugar do Outro, pos. 1261 de 1923 - pos. 1282 de 1923.
} 
Conforme aponta Celia Passos, pesquisadora em Métodos Alternativos de Solução de Conflitos e Práticas Restaurativas, "todo o sistema juvenil da Nova Zelândia é restaurativo, o que simboliza o início da sedimentação dessa estrada"166. A experiência de Azim Khamisa demonstra que a internalização de uma racionalidade restaurativa impede a coisificação do ofensor; por pior que tenha sido o ato praticado, a sua condição humana não é desconsiderada.

O Brasil, muito embora ainda possua uma mentalidade punitivoretributiva socialmente arraigada, começa a dar seus primeiros passos. Em abril de 2005, foi realizado na cidade de Araçatuba/SP o I Simpósio Brasileiro de Justiça Restaurativa, que elaborou a seguinte carta de princípios:

Acreditamos que o modo violento como se exerce o poder, em todos os campos do relacionamento humano, pode ser pacífico, mudando-se os valores segundo os quais compreendemos e as práticas com as quais fazemos justiça em nossas relações interpessoais e institucionais.

Reformular nossa concepção de justiça é, portanto, uma escolha ética imprescindível na construção de uma sociedade democrática que respeite os direitos humanos e pratique a cultura de paz. Essa nova concepção de justiça está em construção no mundo e propõe que, muito mais que culpabilização, punição e retaliações do passado, passemos a nos preocupar com a restauração das relações pessoais, com a reparação dos danos de todos aqueles que foram afetados, com o presente e com o futuro. ${ }^{167}$ - Grifo Nosso.

Quanto ao aspecto legal, inclusive, Samantha Pelajo, Presidente da Comissão de Mediação de Conflitos da OAB-RJ, narra uma história, a título ilustrativo, sobre a qual desenvolve uma análise interpretativa no que concerne à fixação de pena-base, pelo juiz criminal brasileiro, no processo trifásico de dosimetria da pena:

Uma família vive em um vilarejo considerado seguro. Os vizinhos se conhecem, as crianças brincam na rua, janelas e portas permanecem destrancadas. Em algum momento, essa família viaja e, ao retornar das férias, encontra o lar inteiramente destruído e seu gato de estimação morto. Uma sensação de medo e insegurança toma conta de modo que novos hábitos passam a ser adotados. O tempo passa e eles descobrem o autor do dano. Na mediação penal, ao escutarem o rapaz,

\footnotetext{
${ }^{166}$ PASSOS, Celia; BATTAGLIA, Maria do Céu; PELAJO, Samantha. Entrevista concedida a Luisa de Araujo Tavares. 2 out. 2017.

${ }^{167}$ I SIMPÓSIO BRASILEIRO DE JUSTIÇA RESTAURATIVA, 2005. Carta de Araçatuba, Anais Eletrônicos, Araçatuba, São Paulo, 2005. Disponível em: <http://jij.tjrs.jus.br/justicarestaurativa/carta-aracatuba> . Acesso em: 11 out. 2017.
} 
descobrem que, na verdade, ele era um dependente químico que se encontrava sob o efeito de substâncias alucinógenas, não se tratando, o episódio, de um ato de violência gratuito. $\mathrm{O}$ jovem infrator, por sua vez, tomou consciência de como seus atos alteraram o modo de vida e a dinâmica de convivência daquela família - que teve a oportunidade de externar sua dor - e, a partir dessa reflexão autoimplicativa, consentiu, pela primeira vez, em se reabilitar. Em situações como essa, quando o caso vai para a prática restaurativa e as pessoas se resolvem: há respaldo legal para o juiz se valer dessa experiência (em que houve a disponibilidade de reflexão - por parte do autor do fato - das necessidades geradas pelos seus atos, auxílio à dor da vítima e demonstração de responsabilização ativa) para fixar a pena-base mais próximo do mínimo legal. ${ }^{168}$ - Grifo Nosso.

Conclui-se, portanto, que há ainda uma longa jornada pela frente, visto que o que se propõe e almeja é uma mudança de cultura na sociedade com o surgimento de uma nova mentalidade coletiva sobre o conceito de justiça. Por mais desafiador que seja, a história da humanidade atesta a viabilidade de quebras de paradigmas de modo concreto. Conforme todo o disposto acima, os primeiros passos já foram dados - tanto no Brasil como no mundo -, mas "muito há ainda para se caminhar; caberá a cada um que esteja comprometido com a implementação da Justiça Restaurativa, que essa se faça de modo claro, preciso e com a qualidade necessária"169.

\subsection{O ESTÍMULO DOS NEURÔNIOS-ESPELHO EM QUADROS PSICOPÁTICOS}

Talvez, quando isso tudo se transformar mais consistentemente, se encontre alguma outra forma de lidar com aqueles que não têm jeito. Sempre existirão aqueles que não têm jeito. $\mathrm{O}$ que se faz com essas pessoas? Que outras formas nós - sociedade - vamos construir para lidar com essas pessoas que não irão se implicar e nem assumir responsabilidade pela agressão que cometeram? Há que se pensar, mas que a saída não seja o encarceramento do modo que é aplicado nos dias de hoje. ${ }^{170}$ - Grifo Nosso.

O alerta da psicoterapeuta Maria do Céu Battaglia atenta para aqueles indivíduos que não se enquadram, e tampouco se adaptam, nas propostas

\footnotetext{
168 PASSOS, Celia; BATTAGLIA, Maria do Céu; PELAJO, Samantha. Entrevista concedida a Luisa de Araujo Tavares. 2 out. 2017.

${ }^{169}$ ALMEIDA, Tania; PELAJO, Samantha; JONATHAN, Eva (Coord.). Mediação de conflitos: para iniciantes, praticantes e docentes. 1.ed. Salvador: Editora JusPodivm, 2016. PARTE II: para praticantes, Capítulo 7, Justiça Restaurativa, p. 687.

${ }^{170}$ PASSOS, Celia; BATTAGLIA, Maria do Céu; PELAJO, Samantha. Entrevista concedida a Luisa de Araujo Tavares. 2 out. 2017.
} 
elencadas no decorrer deste capítulo - as exceções. Correspondem, por exemplo, a delinquentes cujo perfil seja completamente psicopático, ou seja, casos em que o agente porte um distúrbio de comportamento - psicoses, paranoias, hiperatividade - que não se caracterize como uma alienação mental e, por conseguinte, justifique a aplicação da medida de segurança pela inimputabilidade disposta no artigo 26 do Código Penal Brasileiro ${ }^{171}$. Para o psicólogo Leonardo Fernandes de Araújo:

O psicopata sabe exatamente o que faz, inclusive que tais atos são ilegais ou imorais. Ele tem ciência de que pode ser pego pela polícia e levado à justiça. Sendo assim, o psicopata calcula meticulosamente os seus passos. Um estelionatário ardiloso, por exemplo, planeja cada passo, cada detalhe para que seu plano tenha êxito e para que nada seja descoberto antes do tempo. Tudo o que o psicopata faz é normal e natural, para ele mesmo, é claro. Por não sofrer de remorso ou culpa, comete os piores crimes e atrocidades sem pestanejar. ${ }^{172}$ - Grifo Nosso.

No mesmo sentido, atesta a psiquiatra Hilda Clotilde Penteado

Morana:

O indivíduo reage ao ambiente conforme o percebe, mas, em sendo um psicopata, já o percebe de forma desestruturada devido à escassa disponibilidade afetiva para integrar os fatos. Contudo, esses sujeitos não apresentam a noção do real alterada, ao contrário do que ocorre nos quadros psicóticos ou deficitários. Nos psicopatas, as noções são mais indiferenciadas e ambíguas, consideradas do ponto de vista puramente cognitivo intelectual, mas não há prejuízo significativo do entendimento das situações. ${ }^{173}$ - Grifo Nosso.

A questão é inegavelmente delicada, visto que psicopatas são indivíduos que se diferem dos demais: não absorvem nem reconhecem a punição como uma espécie de correção pela infração cometida. Para eles, o período de punição não passa de uma neutralização de suas atitudes; com

${ }^{171}$ Decreto-Lei 2.848/40, art. 26 - É isento de pena o agente que, por doença mental ou desenvolvimento mental incompleto ou retardado, era, ao tempo da ação ou da omissão, inteiramente incapaz de entender o caráter ilícito do fato ou de determinar-se de acordo com esse entendimento. Parágrafo único - A pena pode ser reduzida de um a dois terços, se o agente, em virtude de perturbação de saúde mental ou por desenvolvimento mental incompleto ou retardado não era inteiramente capaz de entender o caráter ilícito do fato ou de determinar-se de acordo com esse entendimento.

172 ARAÚJO, Leonardo Fernandes de. Apud SILVA, Cláudia. O psicopata e a política criminal Brasileira, 2010. Disponível em: 〈https://www.jurisway.org.br/v2/dhall.asp?id_dh=9440〉. Acesso em: 15 out. 2017.

${ }^{173}$ MORANA, Hilda Clotilde Penteado. Identificação do ponto de corte da escala PCL-R (Psychopathy Checklist-Revised) em população forense brasileira: caracterização de dois subtipos de personalidade; transtorno global e parcial. São Paulo, 2003, p. 113-114. Disponível em: 〈http://www.teses.usp.br/teses/disponiveis/5/5142/tde.../HildaMorana.pdf\%3E〉. Acesso em: 15 out. 2017. 
isso, de acordo com Nelson Hungria, "a modificação da personalidade, no sentido do seu reajustamento social, pode ser, e muitas vezes o é, apenas fingida ou meramente superficial, não atingindo o substrato da intimidade psíquica do indivíduo"174. O psiquiatra Robert Hare elucida:

Os psicopatas, apesar de possuírem padrão intelectual, médio ou até elevado, exteriorizam, no curso da vida, distúrbios da conduta, de natureza antissocial ou que colidem com as normas éticas, e que não são influenciáveis pelas medidas educacionais, ou são insignificantemente modificáveis pelos meios coercitivos e correcionais. ${ }^{175}$ - Grifo Nosso.

Ocorre que o ordenamento jurídico brasileiro é lacunoso quanto à abordagem que deve ser dada para aqueles que carecem de empatia, motivo pelo qual acabam recebendo o mesmo tratamento previsto para aqueles que possuem a capacidade de autoimplicação. O professor Alexandre Magno explica tal problemática com uma interessante metáfora:

No Brasil, os condenados por qualquer crime são vistos pelo Estado da mesma forma que um passageiro de um avião vê a floresta abaixo, ou seja, de modo absolutamente homogêneo. O princípio da individualização da pena é frequentemente esquecido nas penitenciárias, sendo comum o tratamento igualitário de pessoas com personalidades e condutas absolutamente díspares. Raras são as iniciativas dos "biólogos" em se dar ao trabalho de analisar as diferenças entre cada um dos habitantes dessa "floresta". ${ }^{176}$ - Grifo Nosso.

Certo é que "os procedimentos terapêuticos tradicionais não têm apresentado bons resultados na tentativa de modificar o comportamento dos psicopatas"177. A psiquiatra Hilda Morana, já supramencionada, contempla a possibilidade de atenuação dessa conduta desviante, considerando ser infactível, ainda, a anulação completa de tais feições:

Trata-se de um problema cerebral; é um defeito cerebral, então, não tem cura. No entanto, há como atenuar a manifestação desse comportamento, melhorar o funcionamento desse cérebro pelo uso de uma medicação específica. Não vai

\footnotetext{
${ }^{174}$ HUNGRIA, Nelson. Métodos e critérios para a avaliação da cessação de periculosidade. Revista Jurídica, v. 4, nº. 39 ago. 2002, p. 3.

175 HARE, Robert D. Psicopatia: teoria e pesquisa. Tradução: Cláudia Moraes Rêgo. Rio de Janeiro: Livros Técnicos e Científicos, 1973, p. 63.

${ }^{176}$ MAGNO, Alexandre. A urgente necessidade de uma política criminal para os psicopatas. 8 fev. 2008. Disponível em: <http://www.direitonet.com.br/artigos/exibir/4145/A-urgente-necessidadede-uma-politica-criminal-para-os-psicopatas>. Acesso em: 16 out. 2017.

${ }^{177}$ HARE, Robert D. Op. cit., p. 103.
} 
mudar o caráter do psicopata, mas irá fazer com que o seu cérebro funcione um pouquinho melhor. ${ }^{178}$ - Grifo Nosso.

Considerando todas as circunstâncias elencadas, deduz-se a necessidade de submeter pessoas que apresentem uma índole psicopática a um tratamento neuropsicológico que estimule a atuação dos chamados neurônios-espelho, descobertos pela equipe do neurocientista Giacomo Rizzolatti, da Universidade de Parma, na Itália:

Nosso conhecimento motor e a nossa capacidade de 'espelhamento' nos permitem compartilhar uma esfera comum de ação com os outros, dentro do qual cada ato motor ou cadeia de atos motores, sejam eles nossos ou dos demais, são imediatamente detectados e intencionalmente compreendidos antes e independentemente de qualquer mentalização. ${ }^{179}$

O pesquisador Daniel Glaser, da Universidade de Londres, iluminado pelas formulações de Rizzolatti, elucida que:

O que descobrimos é o mecanismo que está por trás de algo que é absolutamente fundamental para o modo que vemos as outras pessoas no mundo. O sistema de espelhos é a maneira que você aproveita as suas próprias habilidades e a forma como as projeta para o mundo. ${ }^{180}$ - Grifo Nosso.

Seguindo essa mesma diretriz, o professor Marco Iacoboni da U.C.L.A acredita que:

Os neurônios-espelho amarram-nos não apenas às ações de outras pessoas, mas também aos seus sentimentos. Eles podem enviar mensagens para o sistema límbico - ou sistema emocional - em nosso cérebro. Então, é possível que esses neurônios nos ajudem a entrar em sintonia com os sentimentos do outro... isso é empatia. ${ }^{181}$ - Grifo Nosso.

O pesquisador e neurocientista Christian Keysers, da Universidade de Groningen, liderou um estudo que investigava a atividade cerebral de

\footnotetext{
${ }^{178}$ MORANA, Hilda Clotilde Penteado. Reportagem especial. Rádio Câmara. Saiba mais sobre a psicopatia: segunda parte. 6min55s. Disponível em: <http://www2.camara.leg.br/camaranoticias/radio/materias/REPORTAGEM-ESPECIAL/369149SAIBA-MAIS-SOBRE-A-PSICOPATIA--SEGUNDA-PARTE \%2806\%2755\%22\%29.htmll. Acesso em: 16 out. 2017.

${ }^{179}$ RIZZOLATTI, Giacomo. Apud TEIXEIRA, Hélio. O que é teoria dos neurônios espelhos?. 21 nov. 2015. Disponível em: $\lfloor$ http://www.helioteixeira.org/gramatica-da-colaboracao/o-que-e-teoriados-neuronios-espelhos/>. Acesso em: 16 out. 2017.

${ }^{180}$ GLASER, Daniel. Apud KRULWICH, Robert. Neurônios Espelho. YouTube. 5 jul. 2016. 14min14s. Disponível em: 〈https://www.youtube.com/watch?v=MYBDyukYwA8>. Acesso em: 16 out. 2017. Trecho: $5 \min 30 \mathrm{~s}-5 \min 42 \mathrm{~s}$.

${ }^{181}$ IACOBONI, Marco. Apud KRULWICH, Robert. Neurônios Espelho. YouTube. 5 jul. 2016. 14min14s. Disponível em: 〈https://www.youtube.com/watch?v=MYBDyukYwA8>. Acesso em: 16 out. 2017. Trecho: $8 \min 35 \mathrm{~s}-8 \mathrm{~min} 50 \mathrm{~s}$.
} 
criminosos psicopatas na Holanda. O experimento foi similar ao que Rizzolatti realizou com macacos: foram exibidos filmes retratando duas mãos interagindo de maneira ora amorosa ora dolorosa. Em um primeiro momento, os infratores simplesmente assistiram aos vídeos, sem nenhuma recomendação. Em seguida, os pesquisadores instruíram-nos a ver novamente as cenas exibidas, só que, desta vez, tentando criar empatia com os personagens.

Os participantes dessa pesquisa foram colocados em um aparelho de ressonância magnética durante a experimentação. Na primeira passagem, seus cérebros indicaram uma baixa atividade de neurônios-espelho em comparação com o padrão do ser humano - o que denota a circunstância de sentirem menos empatia pelos demais. Todavia, quando foram instruídos e convidados a se esforçarem a visitar o lugar do outro, evidenciou-se, nos psicopatas, o mesmo nível, em comparação aos indivíduos normais, de atividade cerebral desses neurônios-espelho. Averígua-se, portanto, que os psicopatas são capazes de desenvolver compaixão se conscientemente a estimularem. Nas palavras de Christian Keysers:

Psicopatas podem ser, por vezes, muito charmosos e socialmente astutos, e, outras vezes, são insensíveis e realizam atrocidades, pois possuem a habilidade de controlar sua empatia. O desafio dos terapeutas não está em produzir empatia, mas sim em encontrar maneiras de torná-la automática. ${ }^{182}$ - Grifo Nosso.

Assim, imperiosa é a imprescindibilidade de uma intervenção especial para aqueles que destoam da maioria. Por essa razão, o que se propõe é a incidência de um tratamento neuropsicanalítico contínuo de incitação do fluxo desses neurônios-espelho no funcionamento cerebral do sujeito de caráter psicopático. Deve ser realizado por profissionais capacitados, com o intuito de promover o sentimento de empatia, para assim viabilizar a tão buscada base restaurativa da autoimplicação.

${ }^{182}$ KEYSERS, Christian apud CIÊNCIA ONLINE. Psicopatas insensíveis também sentem empatia, 2013. Disponível em: 〈http://www.ciencia-online.net/2013/07/psicopatas-sentem-empatia.html>. Acesso em: 16 out. 2017. 
A presente monografia busca, portanto, justamente demonstrar que o encarceramento como punição tem que acabar em qualquer circunstância, pois, como bem expõe Daniel Glaser:

No fundo, a nossa arquitetura, além de nossas células, foi feita para estarmos juntos. O sistema de espelhos é, provavelmente, o sistema social mais básico do cérebro. É um sistema cerebral que não há vantagem em se ter se não for para interagir ou se relacionar com outras pessoas. ${ }^{183}$ - Grifo Nosso.

183 GLASER, Daniel. Apud KRULWICH, Robert. Neurônios Espelho. YouTube. 5 jul. 2016. 14min14s. Disponível em: 〈https://www.youtube.com/watch?v=MYBDyukYwA8>. Acesso em: 16 out. 2017 . Trecho: $13 \min 29 \mathrm{~s}-13 \mathrm{~min} 53 \mathrm{~s}$. 


\section{CONCLUSÃO}

Diante de todo o exposto, resta inequívoco o corolário de que a prisão - seja em caráter preventivo, seja a título de cumprimento de pena - deve ser extinta. O seu surgimento como instrumento sancionador vem por duas principais razões: (1) a demanda de mão-de-obra oriunda da lógica econômica capitalista e (2) as bases de "salvação" e "cura" do Direito Canônico. A era dos suplícios chega ao seu fim com a mitigação das penas, que passam a ser aplicadas de maneira proporcional e razoável, visando à retribuição do mal causado, à prevenção da prática de novos delitos e à ressocialização.

Conforme demonstrado, as contradições da tríade de escopos da pena privativa de liberdade configuram a formação de uma estrutura originalmente fracassada. O sistema penal, nesse cenário, cria - por meio de leis - infinitas tipificações penais com o intuito de maquiar a sua arbitrariedade, possuindo, portanto, na prática, uma atuação seletiva, segregacionista e, por conseguinte, ilegítima. Perante a infactibilidade de se alcançarem os fins - por se tratar de vetores diametralmente opostos -, somada a um inconsciente coletivo punitivo-retributivo, a cadeia se engendra de modo a garantir segurança e disciplina.

Assim, o preso é coisificado, ou seja, são-lhe retiradas a sua individualidade e a sua autonomia, e ele se vê obrigado a prisonar-se para sobreviver aos tratamentos desumanos aos quais é submetido. Desse modo, resta clara a configuração de um regime prisional totalitário que, embora inserido em uma sociedade livre supostamente democrática, muito se distancia das suas feições. Ademais, constatou-se que a assimilação da cultura do cárcere penetra não somente na massa carcerária, como também em todos aqueles que se encontram inseridos na realidade da penitenciária. Comandos de punições vexatórias e humilhantes, ditados pela direção, por exemplo, são aceitos e justificados pela "tábua de valores" intramuros diversa da vigente na comunidade livre. Deflagra-se, portanto, um sistema 
penal-prisional falido, recheado de hipocrisias e paradoxos, que, além de não ressocializar, ainda acarreta danos à psiquê humana.

Considerando tal contexto e com a consciência de que o encarceramento não se tornará em cinzas da noite para o dia, novos rumos precisam ser tomados. Tendo em vista a realidade brasileira, principalmente no que concerne à superlotação dos presídios, Augusto Thompson aponta para a irracionalidade do sistema progressivo, sugerindo, assim, a adoção de um sistema regressivo. Além disso, para desafogar a cadeia, mostra-se útil uma maior abrangência das hipóteses de cabimento - no ordenamento jurídico brasileiro - da aplicação de penas alternativas à prisão, como é o caso das restritivas de direito. O sistema penitenciário, por mais que o seu término esteja muito distante na conjuntura atual, precisa, inegavelmente, ser humanizado. Nesse sentido, a PLS n ${ }^{0} 513 / 2013$ prevê a possibilidade de cumprimento de pena privativa em estabelecimentos como as APACs associação de proteção e assistência aos condenados.

Trata-se, todavia, de medidas de transição, que integram a longa jornada rumo ao aculturamento de uma concepção de justiça restaurativa manuseada por ferramentas autoimplicativas que possibilitam a responsabilização coletiva. Nessa quebra de paradigmas, ao revés da lógica punitivo-retributiva atual, em um sistema restaurativo o autor do ato não perde a sua dimensão humana, sendo capaz de refletir sobre as suas ações e transformar-se. As necessidades advindas pelo esgarçamento da relação dos envolvidos podem ser supridas, e, como restou comprovado, a elaboração do dano - tanto por parte de quem o causou, como também por quem o sofreu quebra o ciclo de violência.

O aprisionamento contradiz a natureza humana. Os homens são seres sociais, espontaneamente empáticos, sendo imprescindível para o seu desenvolvimento a convivência. Até mesmo aqueles que apresentam um quadro de personalidade psicopática são capazes de visitar o lugar do outro se conscientemente estimularem - em um tratamento neuropsicanalítico contínuo e ininterrupto - a atividade dos neurônios-espelho em seus sistemas 
cerebrais. A trajetória da humanidade, em seu processo civilizatório, comprova - ainda que de forma não linear - que mudanças, mesmo que improváveis, são possíveis e essenciais para o crescimento e a evolução de cada indivíduo. 


\section{REFERÊNCIAS BIBLIOGRÁFICAS}

ALMEIDA, Tania; PELAJO, Samantha; JONATHAN, Eva. (Coord.) Mediação de conflitos: para iniciantes, praticantes e docentes. 1.ed. Salvador: Editora JusPodivm, 2016.

O APARTAMENTO. Direção: Asghar Farhadi. Produção: Alexandre Mallet-Guy e Asghar Farhadi. Intérpretes: Shahab Hosseini, Taraneh Alidoosti, Babak Karimi, Mina Sadati, Farid Sajjadi Hosseini, Shirin Aghakashi, Mehdi Koushki, Ehteram Boroumand, Sam Valipour, Maral Bani Adam, Mojtaba Pirzadeh, Sahra Asadollahe, Emad Emami e outros. Roteiro: Asghar Farhadi. Memento Films Production. Arte France Cinéma. PANDORA FILMES. 2016. $125 \mathrm{~min}$.

AZEVÊDO, Jackson C. de. Reforma e contra-reforma penal no Brasil: uma ilusão que sobrevive. Florianópolis: OAB/SC, 1999.

BECCARIA, Cesare. Dos delitos e das penas. Tradução: Torrieri Guimarães. 7.ed. São Paulo: Editora Martin Claret Ltda., 2013.

BITENCOURT, Cezar Roberto. Tratado de Direito Penal - Parte Geral 1. 19.ed. São Paulo: Editora Saraiva, 2013.

BRASIL. Decreto-Lei n ${ }^{0} 2.848$, de 7 de dezembro de 1940. Institui o Código Penal. Disponível em: <http://www.planalto.gov.br/ccivil 03/decretolei/Del2848compilado.htm>. Acesso em: 2 set. 2017.

. Lei $\mathrm{n}^{\circ} 7.210$, de 11 de julho de 1984. Institui a Lei de Execução

Penal.

Disponível

em: 
<http://www.planalto.gov.br/ccivil_03/leis/L7210.htm>. Acesso em: 18 set. 2017.

Lei $\mathrm{n}^{\circ}$ 8.072, de 25 de julho de 1990. Dispõe sobre os crimes hediondos, nos termos do art. $5^{\circ}$, inciso XLIII, da Constituição Federal, e determina outras providências. Disponível em: <http://www.planalto.gov.br/ccivil_03/leis/L8072.htm>. Acesso em: 18 set. 2017.

BUFFARD, Simone. Le Froid Pénitentiaire. Paris: Ed. Seuil, 1973.

CARDOSO, Carlos Raymundo. Entrevista concedida a Luisa de Araujo Tavares. 6 set. 2017.

CARMONA, Helena. Prisão é o maior entrave para ressocialização, indica pesquisa. Jornal da PUC, 5 maio 2017. Disponível em: <http://jornaldapuc.vrc.puc-

rio.br/cgi/cgilua.exe/sys/start.htm?infoid $=5172 \&$ sid=48 $>$. Acesso em: 28 out. 2017.

CARVALHO FILHO, Luís Francisco. A prisão. São Paulo: PubliFolha, 2002.

CHAPMAN, Dennis. Sociology and the Stereotype of the Criminal. Londres: Tavistock Publ., 1968.

CIÊNCIA ONLINE. Psicopatas insensíveis também sentem empatia, 2013. Disponível em: <http://www.ciencia-online.net/2013/07/psicopatas-sentemempatia.html>. Acesso em: 16 out. 2017. 
DAHL, Tove Sang. La intervención estatal y el control social en la Europa del siglo XIX. In: II Conferência do Grupo Europeu para o Estudo do Desvio e Controle Social. Essex, Inglaterra, 1974.

DEL OLMO, Rosa. A América Latina e sua criminologia. Tradução: Francisco Eduardo Pizzolante e Sylvia Moretzsohn. 1.ed. Vol. 9 - Coleção Pensamento Criminológico. São Paulo: Editora Revan, 2004.

DRESSLER, David. Readings in Criminology and Penology. 2.ed. Columbia Un. Press, 1948.

O EXPERIMENTO de Aprisionamento de Stanford. Direção: Kyle Patrick Alvarez. Produção: Brent Emery, Lizzie Friedman, Lauren Bratman, Christopher McQuarrie, Karen Lauder e Greg Little. Intérpretes: Billy Crudup, Ezra Miller, Michael Angarano e outros. Roteiro: Tim Talbott, Christopher McQuarrie e P.W. Hopsidor. Abandon Pictures. UNIVERSAL PICTURES. 2015. $122 \mathrm{~min}$.

FOUCAULT, Michel. Historia de la locura en la época clásica. Tradução: Juan José Utrilla. 1.ed. em espanhol. México: Editora Fondo de Cultura Económica, 1967.

. Vigiar e punir: nascimento da prisão. Tradução: Raquel Ramalhete. 42.ed. Petrópolis: Editora Vozes, 2014.

GOMES, Luiz Flávio. Penas e medidas alternativas à prisão. 2.ed. São Paulo: Revista dos Tribunais, 2000.

HARE, Robert D. Psicopatia: teoria e pesquisa. Tradução: Cláudia Moraes Rêgo. Rio de Janeiro: Livros Técnicos e Científicos, 1973. 
HOBBES, Thomas. Leviatã: ou matéria, forma e poder de um Estado eclesiástico e civil. Coleção Os Pensadores. São Paulo: Nova Cultural, 1997.

HUNGRIA, Nelson. Métodos e critérios para avaliação da cessação de periculosidade. Revista Jurídica, v. 4, nº. 39, ago. 2002.

INSTITUTO LATINO-AMERICANO DAS NAÇÕES UNIDAS PARA PREVENÇÃO DO DELITO E TRATAMENTO DO DELINQUENTE (ILANUD/BRASIL). Levantamento Nacional sobre Execução de Penas Alternativas. 2006.

KAUFMANN, Hilde. Principios para la reforma de la ejecución penal. Buenos Aires: Depalma, 1977.

KRULWICH, Robert. Neurônios Espelho. YouTube. 5 jul. 2016. 14min14s. Disponível em: 〈https://www.youtube.com/watch?v=MYBDyukYwA8> Acesso em: 16 out. 2017.

MAGNO, Alexandre. A urgente necessidade de uma política criminal para os psicopatas. 8 fev. 2008. Disponível em: $<$ http://www.direitonet.com.br/artigos/exibir/4145/A-urgente-necessidadede-uma-politica-criminal-para-os-psicopatas >. Acesso em: 16 out. 2017.

MARAT, Jean-Paul. Plan de législation criminelle. Neuchâtel, 1780.

MATHIESEN, Thomas. The Defences of the Weak. Londres: Tavistock Publ., 1972. 
MELOSSI, Dario; PAVARINI, Massimo. Cárcel y fábrica: los orígenes del sistema penitenciario. Siglos XVI-XIX. 2.ed. México: Siglo XXI, 1985.

MENDES, Gilmar. País discute eficácia do cumprimento de penas alternativas. Ministério da Justiça, 2008. Disponível em: <http://www.mj.gov.br>. Acesso em 5 out. 2017.

MONTESQUIEU, Charles Louis de Secondat, Baron de la Brède e de. Do espírito das leis. Tradução: Pedro Vieira Mota. 9.ed. São Paulo: Martins Fontes, 2008.

MORANA, Hilda Clotilde Penteado. Identificação do ponto de corte da escala PCL-R (Psychopathy Checklist-Revised) em população forense brasileira: caracterização de dois subtipos de personalidade; transtorno global e parcial. São Paulo: 2003, p. 113-114. Disponível em: $<$ http://www.teses.usp.br/teses/disponiveis/5/5142/tde.../HildaMorana.pdf\% 3E>. Acesso em: 15 out. 2017.

. Reportagem especial. Rádio Câmara. Saiba mais sobre a psicopatia: segunda parte. 6min55s. Disponível em: <http://www2.camara.leg.br/camaranoticias/radio/materias/REPORTAGE M-ESPECIAL/369149-SAIBA-MAIS-SOBRE-A-PSICOPATIA-SEGUNDA-PARTE \%2806\%2755\%22\%29.html>. Acesso em: 16 out. 2017.

NOTÍCIAS de uma Guerra Particular. Direção: João Moreira Salles e Kátia Lund. Produção: Raquel Freire Zangrandi. Música: Antonio Pinto. Intérpretes: Rodrigo Pimentel, Paulo Lins, Itamar Silva, Nilton Cerqueira, Carlos Luis Gregório, Hélio Luz e outros. Roteiro: João Moreira Salles e Kátia Lund. BRETZ FILMES. 1999. 57 min. 
PASSOS, Celia; BATTAGLIA, Maria do Céu; PELAJO, Samantha. Entrevista concedida a Luisa de Araujo Tavares. 2 out. 2017.

PORTAL DO CONSELHO NACIONAL DE JUSTIÇA. Levantamento dos Presos Provisórios do País e Plano de Ação dos Tribunais. Disponível em: $<$ http://www.cnj.jus.br/noticias/cnj/84371-levantamento-dos-presosprovisorios-do-pais-e-plano-de-acao-dos-tribunais>. Acesso em: 13 set. 2017.

. Revisão da LEP reforça ações do CNJ para fim de superlotação em presídios. Disponível em: <http://www.cnj.jus.br/noticias/cnj/80826revisao-da-lep-reforca-acoes-do-cnj-para-o-fim-da-superlotacao-nospresidios>. Acesso em: 17 out. 2017.

PROGRESSÃO de pena funciona mal por que é falha ou por que o estado não atende às exigências da lei?. Direção: Marcelo Canellas. Produção: Vera Souto. Edição: Joelson Maia. Técnicos: Paulo Martins e Jorge Sant'anna. Arte: Alexandre Beltran. Imagem: Lúcio Alves. FANTÁSTICO. REDE GLOBO. 6 dez. 2015. 15min47s. Disponível em: <http://g1.globo.com/fantastico/noticia/2015/12/fantastico-ouveespecialistas-e-vitimas-sobre-progressao-de-pena.html>. Acesso em: 13 set. 2017.

RAMOS, Graciliano. Memórias do cárcere. 1.ed. $1^{\circ}$ vol. Brasil: Editora José Olympio, 1953.

ROLIM, Marcos. Justiça restaurativa: para além da punição. In: SLAKMON, C.; DE VITTO, R. C. P.; GOMES PINTO, R. S. (Org.). Justiça Restaurativa: 
um caminho para os Direitos Humanos. Porto Alegre: Instituto de Acesso à Justiça, 2004.

ROUSSEAU, Jean-Jacques. O contrato social e outros escritos. Tradução: Rolando Roque da Silva. 5.ed. São Paulo: Ed. Cultrix, 1995.

SILVA, Cláudia. O Psicopata e a Política Criminal Brasileira. 2010. Disponível em: 〈https://www.jurisway.org.br/v2/dhall.asp?id_dh=9440 $>$. Acesso em: 15 out. 2017.

\section{SIMPÓSIO BRASILEIRO DE JUSTIÇA RESTAURATIVA, 2005. Carta} de Araçatuba, Anais Eletrônicos, Araçatuba, São Paulo, 2005. Disponível em: 〈http://jij.tjrs.jus.br/justica-restaurativa/carta-aracatuba〉. Acesso em: 11 out. 2017.

UM SONHO de Liberdade. Direção: Frank Darabont. Produção: Niki Marvin. Produção executiva: Liz Glotzer e David V. Lester. Intérpretes: Tim Robbins, Morgan Freeman e outros. Roteiro: Frank Darabont. Castle Rock Entertainment. Columbia Pictures e Warner BROS. 1994. 142 min.

SYKES, Gresham M. The Society of Captives. New Jersey: Princeton University Press, 1972.

TEIXEIRA, Hélio. O que é teoria dos neurônios-espelhos?. 21 nov. 2015. Disponível em: <http://www.helioteixeira.org/gramatica-da-colaboracao/oque-e-teoria-dos-neuronios-espelhos/>. Acesso em: 16 out. 2017.

THOMPSON, Augusto. A questão penitenciária. 2.ed. Rio de Janeiro: Editora FORENSE, 1980. 
URY, William. Como chegar ao SIM com você mesmo: o primeiro passo em qualquer negociação, conflito ou conversa difícil. Recurso Digital. Rio de Janeiro: Editora Sextante, 2015.

ZAFFARONI, Eugenio Raúl. Em busca das penas perdidas: a perda da legitimidade do sistema penal. Tradução: Vânia Romano Pedrosa e Amir Lopes da Conceição. 5.ed. Rio de Janeiro: Editora Revan, 1991.

ZEHR, Howard. Trocando as lentes: um novo foco sobre o crime e a justiça. São Paulo: Editora Palas Athena, 2005. 